PAOLA SAMPAIO GONZALES

Dental Management Survey Brazil (DMS-BR): criação e validação de um instrumento de gestão para a odontologia e sua relação com a satisfação profissional

São Paulo

2014 
PAOLA SAMPAIO GONZALES

Dental Management Survey Brazil (DMS-BR): criação e validação de um instrumento de gestão para a odontologia e sua relação com a satisfação profissional

\section{Versão Corigida}

Dissertação apresentada à Faculdade de Odontologia da Universidade de São Paulo, para obter o título de Mestre, pelo Programa de Pós-Graduação em Ciências Odontológicas.

Área de Concentração: Odontologia Social

Orientador: Prof. Dr. Edgard Michel Crosato

São Paulo 
Autorizo a reprodução e divulgação total ou parcial deste trabalho, por qualquer meio convencional ou eletrônico, para fins de estudo e pesquisa, desde que citada a fonte.

Catalogação-na-Publicação Serviço de Documentação Odontológica

Faculdade de Odontologia da Universidade de São Paulo

Gonzales, Paola Sampaio.

Dental Management Survey Brazil (DMS-BR): criação e validação de um instrumento de gestão para odontologia e sua relação com a satisfação profissional / Paola Sampaio Gonzales ; orientador Edgard Michel-Crosato. -- São Paulo, 2014.

150 p. : tab., graf.; $30 \mathrm{~cm}$.

Dissertação (Mestrado) -- Programa de Pós-Graduação em Ciências Odontológicas. Área de Concentração: Odontologia Social. -- Faculdade de Odontologia da Universidade de São Paulo.

Versão corrigida

1. Marketing. 2. Satisfação no trabalho. 3. Odontologia. I. Michel-Crosato, Edgard. II. Título. 
Gonzales PS. Dental Management Survey Brazil (DMS-BR): criação e validação de um instrumento de gestão para a odontologia e sua relação com a satisfação profissional. Dissertação apresentada à Faculdade de Odontologia da Universidade de São Paulo para obter o título de Mestre em Ciências Odontológicas.

Aprovado em: / /2014

\section{Banca Examinadora}

$\operatorname{Prof}(a)$. Dr(a).

Instituição: Julgamento:

$\operatorname{Prof}(a)$. $\operatorname{Dr}(a)$.

Instituição: Julgamento:

Prof(a). $\operatorname{Dr}(a)$.

Instituição: Julgamento: 
Dedico esse trabalho aos meus pais, André e Sonia, com todo o meu amor. 


\section{AGRADECIMENTOS}

À Comissão de Pós-graduação da Universidade de São Paulo.

Ao Prof. Dr. Edgard Michel Crosato, por toda orientação, liberdade de escolhas e companheirismo durante a realização deste trabalho.

Às secretarias do Departamento de Odontologia Social, em especial, à Andréia, que sempre recebeu as solicitações com um sorriso, e à Sonia, que prontamente atendia a todos os pedidos.

Aos dentistas que participaram deste trabalho e reconheceram sua importância para a Odontologia: Dr. Renato Koga, Dra. Lucy Shiratory, Dra. Simone Magalhães, Dr. Marco Antônio Kulik, Dr. Eduardo Kian, Dra. Kazumi, Dr. Gláucio, Dra. Mariana Bentes, Dra. Beatriz Garneiro, Dra. Alessandra Pedralli, Dr. Roberto Brandi e seu filho Dr. Roberto S. Brandi, Dr. Rodrigo Bomtempi.

Aos responsáveis pelos blogs e/ou páginas na internet pelo auxílio na divulgação e incentivo: Odontodivas, Blog do Dentista, ABOE, APCD Bauru, Dentalis e o grupo Odontologia do Brasil, coordenado pelo Dr. Marcos Santana.

A todos os dentistas que responderam o questionário via internet. Este trabalho só foi possível ser realizado com suas contribuições.

Aos meus pais, por me permitirem alcançar este degrau, pelo incansável incentivo e pela compreensão.

À minha tia Carem, pelo apoio.

Ao Rodrigo Esteves Almeida, pela compreensão e companheirismo durante essa jornada. 
Ao Marcelo e à Fabiana, sócios da empresa DOACOMM, pelo apoio ao longo do período de realização deste trabalho.

A todos os professores que de alguma forma participaram dessa jornada, em especial: Prof. Dr. Ismar Filho, Profa. Dra. Maria Gabriela Haye Biazevic, Profa. Dra. Maria Ercília de Araújo, Prof. Dr. Dalton Luiz de Paula Ramos e Profa. Dra. Fernanda Carrer.

Aos meus colegas da pós-graduação Jaqueline Montoril, Andréa Melani, Mariana Gabriel, Thais Lopes, Márcia, Paulo, Alana, Graciela, Gláucio e Eduardo. 
"A mais bela coisa que podemos vivenciar é o mistério. Ele é fonte de qualquer arte verdadeira e qualquer ciência. Aquele que desconhece esta emoção, aquele que não para mais para pensar e não se fascina, está como morto: seus olhos estão fechados."

Albert Einstein 


\section{RESUMO}

Gonzales PS. Dental Management Survey Brazil (DMS-BR): criação e validação de um instrumento de gestão para a odontologia e sua relação com a satisfação profissional [dissertação]. São Paulo: Universidade de São Paulo, Faculdade de Odontologia; 2014. Versão Corrigida.

As dimensões que abrangem a satisfação no trabalho, a qual tem impactos na qualidade de vida e saúde física e mental do trabalhador, podem interceptar aspectos de gestão. Assim, o objetivo deste estudo foi criar e validar a escala Dental Management Survey Brazil (DMS-BR) e descobrir possíveis relações com a satisfação profissional a partir da escala Dentist Satisfaction Survey (DSS), já validada para a língua portuguesa. A pesquisa foi aprovada no Comitê de Ética em Pesquisa da FOUSP. A criação do instrumento DMS-BR envolveu uma pesquisa na literatura sobre gestão de serviços odontológicos. Depois de criada a primeira versão, foram realizadas 10 auditorias em consultórios odontológicos particulares da Grande São Paulo para verificação da aplicabilidade do instrumento. Nesta etapa, o instrumento foi modificado até chegar em sua versão final, cuja composição consiste em 9 dimensões: ponto, paciente, financeiro, marketing, concorrência, qualidade, equipe, carreira e produtividade. A acurácia do instrumento foi medida por meio da diferença estatística das respostas de 9 profissionais, que responderam o questionário em um intervalo de 30 dias. Os resultados mostraram que não houve diferença estatisticamente significantes entre os dois momentos, garantindo a acurácia do instrumento. $\mathrm{Na}$ fase de validação do instrumento, 247 cirurgiões-dentistas, sendo a grande maioria de São Paulo, responderam o questionário on-line, juntamente com a escala DSS de satisfação profissional. Os resultados mostram que o instrumento possui boa confiança externa e validade interna (Alpha de Cronbach $=0,925$ ) e está validado. A média geral dos respondentes foi de $3,77(\mathrm{DP}=0,45)$, sendo 4,23 ( $\mathrm{DP}=0,54)$ para a dimensão ponto; $4,10(\mathrm{DP}=0,47)$ para a dimensão qualidade; 4,02 (DP= $0,56)$ para a dimensão equipe; $3,87(\mathrm{DP}=0,64)$ para a dimensão carreira; 3,85 $(\mathrm{DP}=0,53)$ para a dimensão paciente; $3,73(\mathrm{DP}=0,64)$ para a dimensão produtividade; $3,68(\mathrm{DP}=0,62)$ para a dimensão concorrência; $3,47(\mathrm{DP}=0,72)$ 
para a dimensão financeiro; e 3,10 (DP= 0,71) para a dimensão marketing. Observa-se que os indicadores críticos da gestão na Odontologia foram correspondentes às dimensões ponto, qualidade e equipe. A satisfação profissional da amostra mostrou-se neutra, com média de 3,43 ( $\mathrm{DP}=0,53)$. Os constructos da escala DMS-BR mostraram-se capazes de impactar a satisfação profissional da amostra estudada, sendo que as dimensões que mais influenciaram a satisfação profissional foram produtividade, financeiro e paciente. Assim, conclui-se que a gestão no âmbito da odontologia pode impactar a satisfação com a atividade laboral.

Palavras-chave: Marketing. Satisfação profissional. Gestão. Odontologia. 


\begin{abstract}
Gonzales PS. Dental Management Survey Brazil (DMS-BR): creation and validation of a management instrument for Dentistry and the relationship with the job satisfaction [dissertation]. São Paulo: Universidade de São Paulo, Faculdade de Odontologia; 2014. Versão Corrigida.
\end{abstract}

Many dimensions that reach the job satisfaction, which have impacts on quality of life and physical and mental health worker, become many times by scope of management. So, the objective of this study was create and validate the Dental Management Survey Brazil (DMS-BR) scale and discover possible relations with the job satisfaction using Dentist Satisfaction Survey (DSS) scale, already validated to Portuguese language. The research was approved in the Ethics in Research Committee of FOUSP. The process of creation of the DMS-BR involved a research in literature about management of Dentistry services. After created the first version were performed 10 audits in private dental offices of Grande São Paulo for the verification of the applicability of the instrument. In this stage, the instrument was modified until arrives at its final version, whose the composition consists in 9 dimensions: place, patient, marketing, financial, rivalry, quality, team, career and productivity. To verify the accuracy, the questionnaire was answered by 9 professionals in a interval of 30 days and the answers did not show statistical differences. For the validation process of the instrument, 247 dental surgeons, being the majority of São Paulo, answered the on-line questionnaire, together with the DSS scale about job satisfaction. The results showed that the instrument has good external confidence and internal valiance (Alpha de Cronbach $=0,925$ ) and it is validated. The overall average of respondents was $3,77(\mathrm{DP}=0,45)$, being 4,23 $(\mathrm{DP}=0,54)$ to the place dimension; $4,10(\mathrm{DP}=0,47)$ to the quality dimension; 4,02 $(\mathrm{DP}=0,56)$ to the team dimension; $3,87(\mathrm{DP}=0,64)$ to the career dimension; 3,85 $(D P=0,53)$ to the patient dimension; $3,73(D P=0,64)$ to the productivity dimension; 3,68 (DP=0,62) to the rivalry dimension; $3,47(\mathrm{DP}=0,72)$ to the financial dimension; and $3,10(\mathrm{DP}=0,71)$ to the marketing dimension. It was observed that the critic indicators of management in Dentistry were correspondents to the place, quality and team dimensions. The job satisfaction of the sample was neutral, averaging 3,43 ( $D P=0,53)$. The scale constructs DMS-BR demonstrate capable to impact the job satisfaction of the studied sample, and the 
most influent dimensions of the job satisfaction were the productivity, financial and patient. By this findings, it is possible to conclude that management applied to Dentistry can be associated with the job satisfaction.

Keywords: Marketing. Job satisfaction. Management. Dentistry. 


\section{LISTA DE QUADROS}

Quadro 4.1 - Parâmetros analisados na dimensão ponto 59

Quadro 4.2 - Parâmetros analisados na dimensão paciente. 59

Quadro 4.3 - Parâmetros analisados na dimensão financeiro 60

Quadro 4.4 - Parâmetros analisados na dimensão marketing 60

Quadro 4.5 - Parâmetros analisados na dimensão concorrência 61

Quadro 4.6 - Parâmetros analisados na dimensão qualidade. 61

Quadro 4.7 - Parâmetros analisados na dimensão equipe 62

Quadro 4.8 - Parâmetros analisados na dimensão carreira 62

Quadro 4.9 - Parâmetros analisados na dimensão produtividade 62

Quadro 4.10 - Parâmetros analisados no bloco satisfação geral 63

Quadro 4.11 - Parâmetros analisados no bloco percepção de renda 64

Quadro 4.12 - Parâmetros analisados no bloco tempo pessoal 64

Quadro 4.13 - Parâmetros analisados no bloco tempo profissional 64

Quadro 4.14 - Parâmetros analisados no bloco equipe 64

Quadro 4.15 - Parâmetros analisados no bloco relacionamento com pacientes 65 
Quadro 4.16 - Parâmetros analisados no bloco fornecimento de assistência/

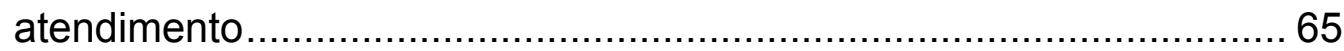

Quadro 4.17 - Tabulações das respostas da escala de satisfação 65 


\section{LISTA DE TABELAS}

Tabela 5.1 - Valores de média, diferença entre as médias e p para as respostas da fase de validação do questionário do instrumento DMS-BR

Tabela 5.2 - Caracterização da amostra por especialidades odontológicas 70

Tabela 5.3 - Caracterização da amostra por dados de região de trabalho, anos de formação e área de atuação

Tabela 5.4 - Frequência de resposta para o instrumento DMS-BR (dimensão: ponto)

Tabela 5.5 - Frequência de resposta para o instrumento DMS-BR (dimensão: paciente)

Tabela 5.6 - Frequência de resposta para o instrumento DMS-BR (dimensão: financeiro)

Tabela 5.7 - Frequência de resposta para o instrumento DMS-BR (dimensão: marketing)

Tabela 5.8 - Frequência de resposta para o instrumento DMS-BR (dimensão: concorrência)

Tabela 5.9 - Frequência de resposta para o instrumento DMS-BR (dimensão: qualidade)

Tabela 5.10 - Frequência de resposta para o instrumento DMS-BR (dimensão: equipe)

Tabela 5.11 - Frequência de resposta para o instrumento DMS-BR (dimensão: carreira).

Tabela 5.12 - Frequência de resposta para o instrumento DMS-BR (dimensão: produtividade)

Tabela 5.13 - Valores de Média e Desvio Padrão para cada dimensão do instrumento DMS-BR

Tabela 5.14 - Média das respostas para o instrumento DMS-BR para as questões da dimensão ponto. 
Tabela 5.15 - Média das respostas para o instrumento DMS-BR para as questões da dimensão paciente

Tabela 5.16 - Média das respostas para o instrumento DMS-BR para as questões da dimensão financeiro.

Tabela 5.17 - Média das respostas para o instrumento DMS-BR para as questões da dimensão marketing

Tabela 5.18 - Média das respostas para o instrumento DMS-BR para as questões da dimensão concorrência

Tabela 5.19 - Média das respostas para o instrumento DMS-BR para as questões da dimensão qualidade

Tabela 5.20 - Média das respostas para o instrumento DMS-BR para as questões da dimensão equipe

Tabela 5.21 - Média das respostas para o instrumento DMS-BR para as questões da dimensão carreira.

Tabela 5.22 - Média das respostas para o instrumento DMS-BR para as questões da dimensão produtividade.

Tabela 5.23 - Análise psicométrica da dimensão ponto do instrumento DMS-BR .... 92

Tabela 5.24 - Análise psicométrica da dimensão paciente do instrumento DMS-BR

Tabela 5.25 - Análise psicométrica da dimensão financeiro do instrumento DMS-BR

Tabela 5.26 - Análise psicométrica da dimensão marketing do instrumento DMS-BR

Tabela 5.27 - Análise psicométrica da dimensão concorrência do instrumento DMS-BR

Tabela 5.28 - Análise psicométrica da dimensão qualidade do instrumento

DMS-BR 
Tabela 5.29 - Análise psicométrica da dimensão equipe do instrumento DMS-BR.

Tabela 5.30 - Análise psicométrica da dimensão carreira do instrumento DMS-BR

Tabela 5.31 - Análise psicométrica da dimensão produtividade do instrumento DMS- BR.

Tabela 5.32 - Correlação de cada uma das dimensões e o DMS-BR 100

Tabela 5.33 - Frequência de resposta para o questionário satisfação no trabalho (bloco: satisfação geral)

Tabela 5.34 - Frequência de resposta para o questionário satisfação no trabalho (bloco: renda)

Tabela 5.35 - Frequência de resposta para o questionário satisfação no trabalho (bloco: tempo pessoal)

Tabela 5.36 - Frequência de resposta para o questionário satisfação no trabalho (bloco: tempo profissional)

Tabela 5.37 - Frequência de resposta para o questionário satisfação no trabalho (bloco: equipe)

Tabela 5.38 - Frequência de resposta para o questionário satisfação no trabalho (bloco: paciente)

Tabela 5.39 - Frequência de resposta para o questionário satisfação no trabalho (bloco: fornecimento de assistência).

Tabela 5.40 - Valores de Média e Desvio Padrão para cada dimensão da escala DSS

Tabela 5.41 - Distribuição dos cirurgiões-dentistas segundo satisfação no trabalho (bloco: satisfação geral)

Tabela 5.42 - Distribuição dos cirurgiões-dentistas segundo satisfação no trabalho (bloco: renda) 
Tabela 5.43 - Distribuição dos cirurgiões-dentistas segundo satisfação no trabalho (bloco: tempo pessoal).

Tabela 5.44 - Distribuição dos cirurgiões-dentistas segundo satisfação no trabalho (bloco: tempo profissional)

Tabela 5.45 - Distribuição dos cirurgiões-dentistas segundo satisfação no trabalho (bloco: equipe)

Tabela 5.46 - Distribuição dos cirurgiões-dentistas segundo satisfação no trabalho (bloco: paciente).

Tabela 5.47 - Distribuição dos cirurgiões-dentistas segundo satisfação no trabalho (bloco: fornecimento de assistência).

Tabela 5.48 - Relação entre a escala DMS-BR e a escala de satisfação profissional

Tabela 5.49 - Relação entre a escala de satisfação profissional e a escala DMS-BR 


\section{LISTA DE ABREVIATURAS E SIGLAS}

AMA

CEP

CFO

CONEP

DMS-BR

DP

DSS

FUNDECTO

Mín

Max

SUS

UNIP
American Marketing Association

Comitê de Ética em Pesquisa

Conselho Federal de Odontologia

Conselho Nacional de Ética em Pesquisa

Dental Management Survey Brazil

Desvio Padrão

Dentist Satisfaction Survey

Fundação para o Desenvolvimento Científico e Técnico da Odontologia

Mínima

Máxima

Sistema Único de Saúde

Universidade Paulista 
1 INTRODUÇÃO

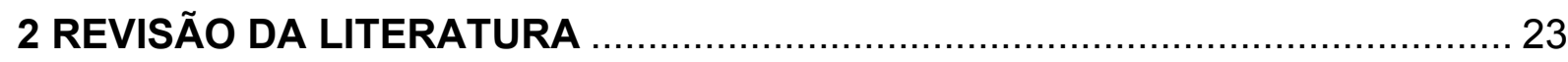

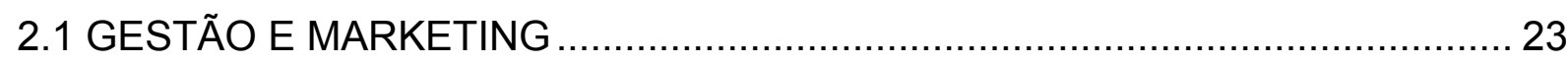

2.1.1 Definição e origem do marketing de serviço ........................................ 24

2.1.2 Histórico do mercado da área da saúde sob a perspectiva do consumo. 26

2.1.3 Conhecimento e aplicação de gestão por cirurgiões-dentistas 27

2.1.4 Atitude de paciente e de profissionais da área da saúde quanto às práticas de marketing

2.1.5 Percepção e expectativas dos pacientes em relação aos serviços odontológicos

2.1.6 Currículo nas faculdades de odontologia e perfil dos alunos e egressos

2.2 SATISFAÇÃO PROFISSIONAL 43

2.2.1 Satisfação profissional do cirurgião-dentista....................................... 45

2.2.1.1 Satisfação dos cirurgiões-dentistas em diversos países ............................ 45

2.2.1.2 Satisfação profissional de cirurgiões-dentistas no Brasil............................ 50

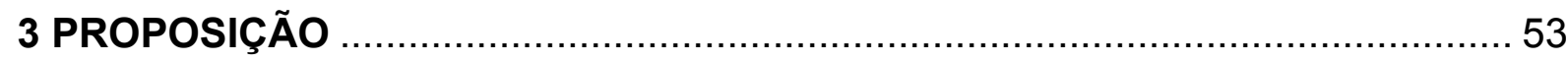

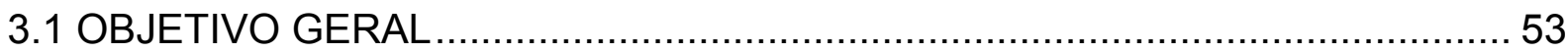

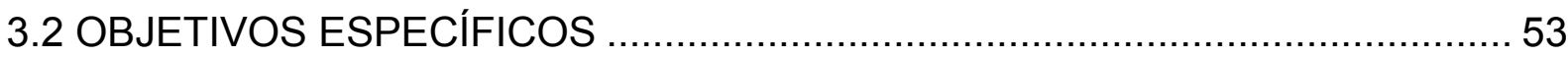

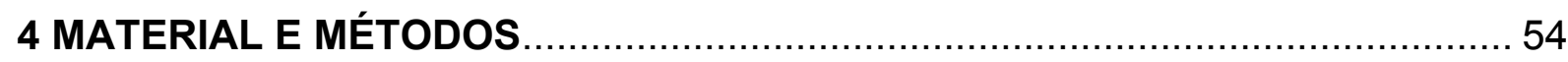

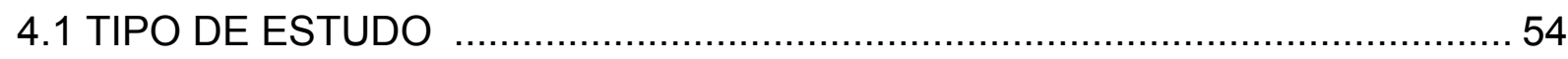

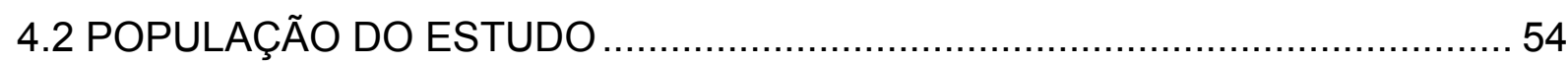

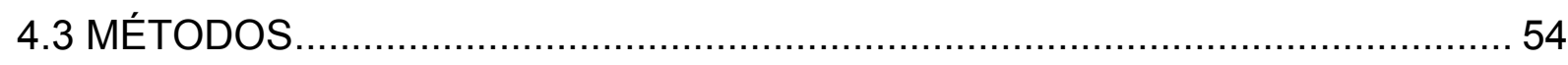

4.3.1 Desenvolvimento e validação do DMS-BR ………................................. 54

4.3.1.1 Fase 01: desenvolvimento do questionário .............................................. 55

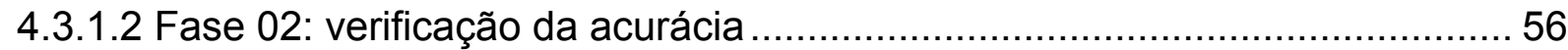

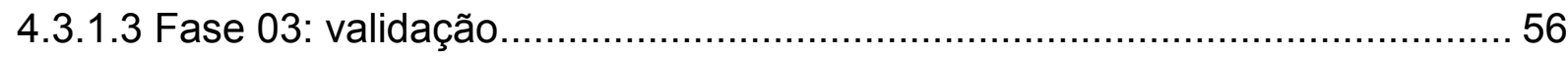

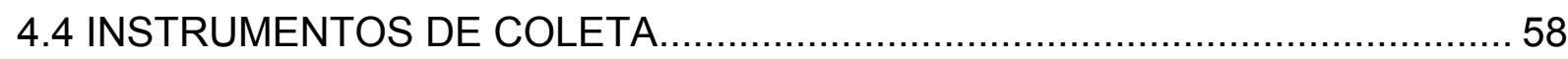

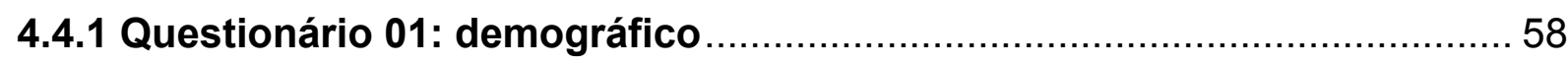

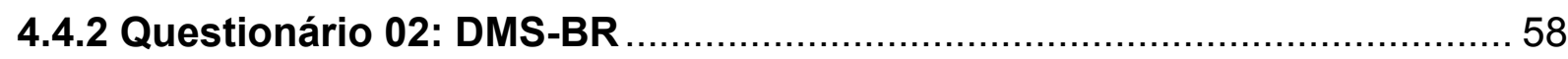

4.4.3 Questionário 03: escala sobre satisfação profissional............................. 63 


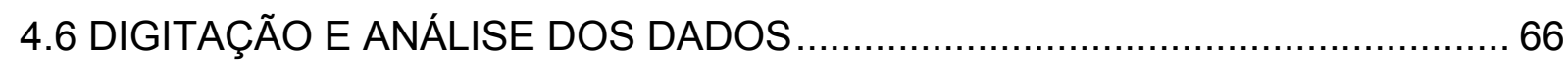

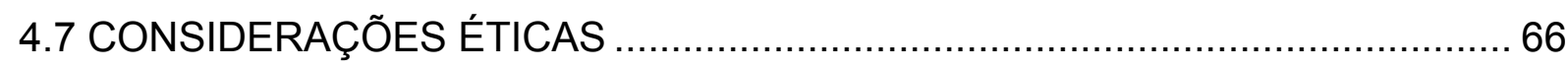

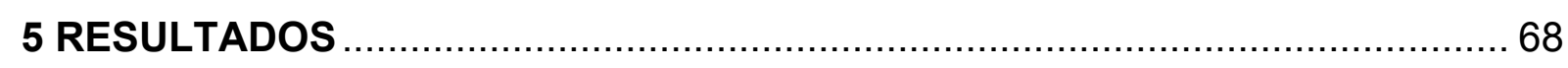

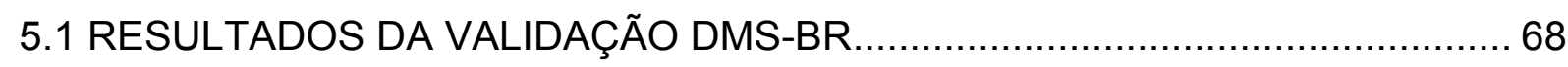

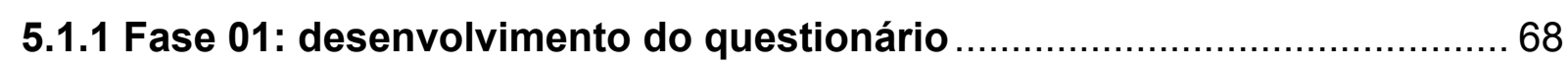

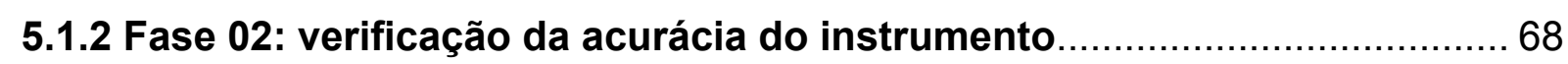

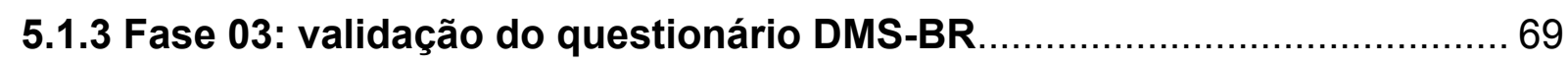

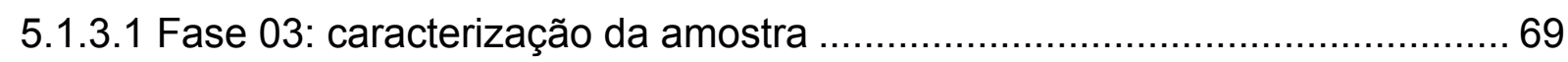

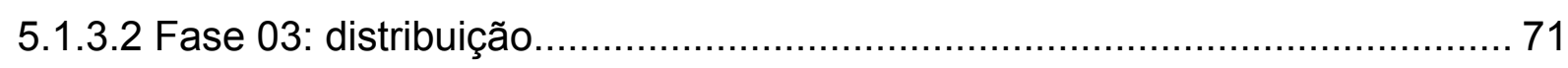

5.1.3.3 Fase 03: média dos resultados por dimensão da escala DMS-BR ............... 82

5.1.3.4 Análise psicométrica da escala DMS-BR por dimensão .............................. 91

5.1.3.5 Correlação das dimensões que compõem o instrumento DMS-BR .............. 99

5.2 SATISFAÇÃO PROFISSIONAL ............................................................... 100

5.2.1 Distribuição de respostas da escala DSS …….................................... 100

5.2.2 Média dos resultados do questionário DSS .......................................... 108

5.3 RELAÇÃO ENTRE A ESCALA DMS-BR E DSS .......................................... 114

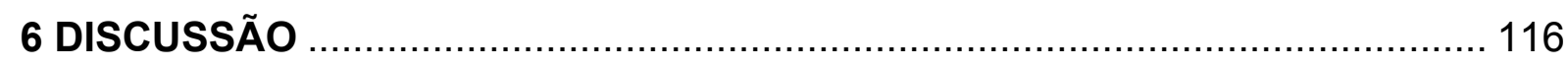

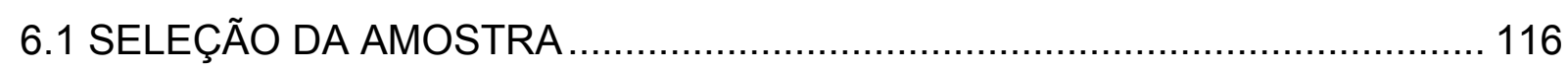

6.2 CARACTERIZAÇÃO DA AMOSTRA ........................................................... 116

6.3 DMS-BR: GESTÃO COM FOCO NA ODONTOLOGIA - CURRÍCULO DE FACULDADES, CONHECIMENTO POR PARTE DOS PROFISSIONAIS E DESAFIOS DO MERCADO DE TRABALHO....................................................119

6.4 SATISFAÇÃO PROFISSIONAL.............................................................127

6.5 SATISFAÇÃO PROFISSIONAL RELACIONADA COM O USO DA GESTÃO NA

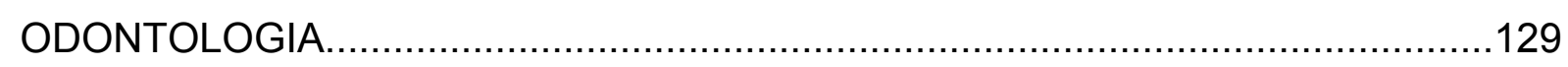

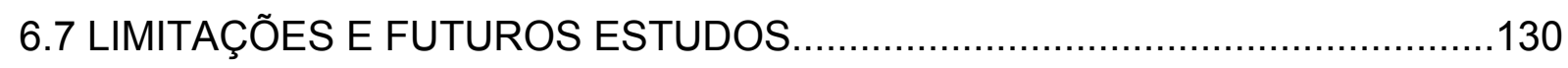

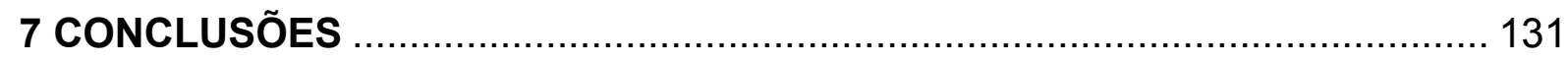

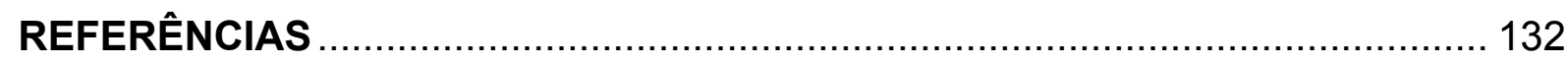

APÊNDICES

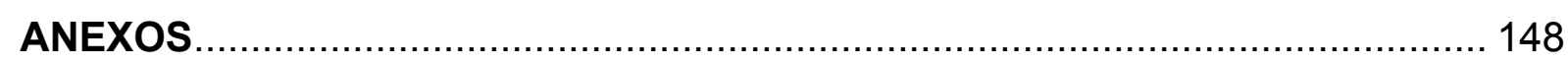




\section{INTRODUÇÃO}

A maioria dos estudantes de odontologia almeja exercer sua atividade em um consultório próprio e a grande maioria consegue atingir esse objetivo em algum momento de sua vida profissional. Essa situação contribui para uma grande oferta de dentistas no âmbito particular, mesmo com o aumento de ofertas no setor público que pode ser observado nas última décadas. Em contrapartida, isso provoca uma saturação do mercado odontológico, principalmente nos grandes centros urbanos do país, onde está concentrado o maior número de profissionais de odontologia e também o maior número de faculdades (Bastos et al., 2003; Crosato, 2003; MichelCrosato, 2008; Morita et al., 2010; Ponte, 2012).

Tendo em vista essa realidade, passa a ser um desafio do dia a dia, para os profissionais inseridos no setor privado, saber lidar com um mercado saturado, gerir os recursos humanos para a contratação e treinamento de pessoal auxiliar, controlar o fluxo de caixa, administrar o estoque e as compras de materiais e equipamentos, investir em formas de atrair e manter os clientes por meio do marketing, assim como pensar estrategicamente em vantagens competitivas para se manter no mercado.

Dessa forma, para obter sucesso profissional do ponto de vista da manutenção de um negócio no mercado, atualmente não basta apenas deter conhecimento técnico-científico, mas também é necessário desenvolver as habilidades administrativas, uma vez que a sobrevivência de uma empresa, como um consultório odontológico, está intimamente relacionada com a eficiência de sua gestão (Drucker, 1998).

Contudo, existe uma grande lacuna entre o ensino nas Universidades e as funções que serão exigidas do profissional no exercício pleno de sua profissão, apesar de as habilidades de administração e gerenciamento estarem inseridas nas Diretrizes Curriculares Nacionais para o curso de Odontologia. A literatura da área relata que conhecimentos sobre gestão (que englobam, entre outros aspectos, finanças, recursos humanos, planejamento estratégico, monitoramento da concorrência e até aspectos legais nas esferas de contratos, obrigações e deveres do prestador de serviços) são enxergados pelos cirurgiões-dentistas como deficientes, porém essenciais a uma boa prática da odontologia. Muitos concordam também que esses conhecimentos devem ser abordados em cursos de graduação, 
com um conteúdo focado na área da Odontologia (Oliveira; Oliveira Jr., 1999; Nicolielo; Bastos, 2002; Gorter et al., 2008; Ponte, 2008; Ribas et al., 2010).

Convergindo com a gestão, para a odontologia poder ser exercida plenamente em sua excelência, é preciso que o profissional alcance pelo menos um nível mínimo de satisfação profissional que o motive a oferecer o seu melhor, tanto para o paciente quanto para a prática de atividades administrativas em seu consultório.

Por definição, a satisfação profissional pode ser compreendida como um importante estado emocional que se desenvolve a partir da confluência de diversos fatores inerentes ao exercício profissional e pode influenciar na qualidade de vida do trabalhador, assim como em sua saúde mental, saúde física e autoestima (Nicolielo; Bastos, 2002). Como esse fenômeno é de origem multifatorial, complexo e dependente da integração das atitudes e vivências do indivíduo e suas percepções em relação às características da atividade exercida, seria superficial e pouco esclarecedor apenas questionar dicotomicamente o profissional sobre a sua satisfação com a atividade que exerce.

Então, a fim de mensurar esse fenômeno, foram criadas diversas escalas para serem aplicadas na Odontologia. A Dentist Satisfaction Survey (Shugars et al., 1991) abrange 54 itens em 11 constructos referentes à profissão: equipe, entrega de cuidados, relacionamento com paciente, percepção de renda, tempo pessoal, práticas de gestão, ambiente profissional, relações profissionais, tempo profissional, respeito, equipe e estresse. Outros autores defendem que a mensuração da satisfação profissional pode ser realizada a partir do estudo de 6 aspectos da profissão: respeito percebido pelo profissional, percepção de renda, fornecimento de assistência, estresse, relações com o paciente e tempo profissional (Wells; Winter, 1999).

Embora não seja consenso entre os autores e não haja um padrão ouro (Van Saane et al., 2003), existem alguns aspectos da satisfação profissional que parecem ser impactados com uma administração e uma gestão eficaz, como por exemplo as dimensões referentes a tempo pessoal, que tem relação com a carga de trabalho do profissional, percepção de renda referente aos seus ganhos, e equipe, que abordam principalmente o rendimento do pessoal auxiliar.

Assim, podem ser observados indícios de que o conhecimento e a aplicação de ferramentas de gestão/marketing na atividade profissional do cirurgião-dentista 
poderia impactar de alguma forma a satisfação profissional. Nesse contexto, e devido à importância do tema, a proposição do presente trabalho é criar e validar uma escala sobre gestão na Odontologia e verificar sua relação com a satisfação profissional. 


\section{REVISÃO DA LITERATURA}

Para facilitar a leitura, a revisão de literatura será apresentada em 2 blocos: gestão/marketing no contexto da odontologia e satisfação profissional. Cada bloco também será desmembrado por assunto para melhor entendimento do leitor.

\subsection{GESTÃO E MARKETING}

Em 1985, a American Marketing Association (AMA) definiu o marketing como sendo um processo que envolvia o planejamento e a execução de conceitos, precificação, promoção e distribuição de bens, ideias e serviços para criar trocas com a meta de satisfazer os objetivos dos indivíduos e das empresas.

Contribuindo com o assunto, Kotler (2000) definiu o termo como sendo o processo social pelo qual pessoas e grupos de pessoas obtêm aquilo de que necessitam e que desejam a partir da criação, oferta e livre negociação de produtos e serviços de valor. Ainda na mesma obra, o autor complementa a definição dizendo que o marketing é uma ciência e também uma arte com o objetivo de conquistar e manter relacionamentos com clientes por meio do desenvolvimento de um relacionamento lucrativo com eles.

Como o mercado é dinâmico e dependente do momento histórico de um país e/ou uma população, a AMA renovou ao longo do tempo sua definições sobre o marketing como, por exemplo, em 2004, ano em que o marketing foi divulgado como uma função organizacional e um conjunto de processos para criar, comunicar e distribuir valor aos clientes e para administrar o relacionamento com clientes de forma que beneficie a organização e os seus stakeholders. A sua definição mais atual defende o marketing como sendo uma atividade que envolve diversos processos para criar, comunicar, entregar e trocar ofertas que tenham valor para os consumidores, clientes, parceiros e sociedade como um todo.

Em específico para a área da odontologia, Paim et al. (2008) relata que, por meio do conhecimento de mercado e público-alvo, uma das funções do 
marketing na odontologia é estabelecer o relacionamento do profissional com o paciente de uma forma que seja benéfica para ambos.

Acerca do termo gestão, que será amplamente usado nesta dissertação, Dias (2011, p. 11) diz que:

Gerir é lançar mão de todas as funções (técnica, contábil, financeira, comercial, segurança e administrativa) e conhecimentos (psicologia, antropologia, estatística, mercadologia, ambiental, etc) necessários para através de pessoas atingir os objetivos de uma organização de forma eficiente e eficaz.

Entende-se também que o objetivo da gestão é garantir que as decisões tomadas resultem em contribuições para a melhoria do desempenho da empresa, por meio de um processo que contempla o planejamento, a execução e o controle das ações (ludícibus et al., 2001).

Como em geral, pensando no pequeno porte das clínicas e consultórios odontológicos, as funções do marketing e da gestão acabam se confundindo, os objetivos a serem alcançados na gestão são em grande parte os mesmo do marketing, pode-se entender que o termo marketing englobado na esfera da gestão, por isso ambos os termos serão, em alguns momentos, usados como sinônimos nesta dissertação.

\subsubsection{Definição e origem do marketing de serviço}

O conceito de marketing originou-se a partir de novas necessidades causadas pelas mudanças socioeconômicas da sociedade. A Revolução Comercial, a Revolução Industrial e a Segunda Revolução Industrial resultaram em um grande contingente populacional capaz de absorver os produtos das empresas, que, por sua vez, focaram na produção.

Entretanto, durante o período de 1869 a 1930, houve uma mudança do cenário socioeconômico e político dos países industrializados, devido ao declínio gradativo do índice de crescimento populacional na Europa e EUA, além da Grande Depressão de 1929, fazendo com que as empresas mudassem o foco da produção para a venda. Com o aumento das ofertas dos produtos e a modificação 
do comportamento dos consumidores, inicia-se o interesse das organizações pelo marketing (Keith,1960).

Durante muito tempo o termo marketing foi utilizado para promover produtos, mas, segundo estudiosos desta área (Brown et al., 1994), em 1977, foi feito o primeiro questionamento sobre a aplicabilidade do marketing de produtos aos serviços, devido às diferenças entre suas características e o comportamento de consumo. Esse primeiro questionamento é atribuído ao artigo "Breaking free from product marketing" publicado no Journal of Marketing por Shostack (1977). A partir de então, o marketing de serviços foi estudado separadamente do marketing de produtos.

Kotler (1994) define serviço como qualquer ato ou desempenho que uma parte possa oferecer a outras partes, que seja essencialmente intangível e não resulte em sua propriedade. Sua produção pode ou não estar vinculada a um produto físico. Já, Vargo e Lusch (2004) defendem que o serviço é resultado da aplicação de competências especializadas, sejam elas habilidades ou conhecimentos, e estão na dependência de ações, processos e atuações para existirem e poderem gerar uma experiência ao usuário.

Por sua vez, Lovelock e Wirtz (2011) ainda explicam que os serviços possuem características diferentes dos produtos, como o fato de os primeiros serem intangíveis, isto é, o consumidor não pode pegar o serviço para experimentá-lo; ou, ainda, por não serem passíveis de estocagem, pois muitas vezes necessitam da participação do consumidor para que o ato seja consumado; além disso, há o seu caráter de simultaneidade, que se refere ao fato de o consumidor poder avaliar a qualidade do serviço conforme ele está sendo desenvolvido. Devido às suas características, os cuidados de saúde no âmbito privado, que incluem a Odontologia, podem ser inseridos no Marketing de Serviços. 


\subsubsection{Histórico do mercado da área da saúde sob a perspectiva do consumo}

A historiadora Nancy Tomes (Tomes, 2001), em seu artigo sobre a medicina e a cultura do consumo dos EUA durante o período de 1900 a 1940, revela diversos aspectos do marketing na área da saúde. Sua pesquisa será apresentada resumidamente nos parágrafos seguintes.

No início do século $X X$, os pacientes tinham poucas fontes de informações para comparar o desempenho do médico ou do tratamento em relação ao preço cobrado, sendo a confiança e o relacionamento que tinham com seus médicos atributos importantes para a escolha do profissional. Mesmo com o advento do marketing nas organizações, os pacientes não se comportavam como consumidores convencionais diante da escolha de seus médicos ou na relação de serviço estabelecida com eles, pois não viam os seus guardiões da saúde como um homem de negócios.

Por mais que a medicina não fosse vista como um negócio, no começo da década de 1930, os gastos com a saúde movimentaram US\$3,5 bilhões (referentes a $4 \%$ ou $5 \%$ do Produto Interno Bruto), mesmo durante a Grande Depressão. Ainda, com os adventos da ciência, os tratamentos se tornaram mais eficazes e também mais caros, haja vista que os gastos com serviços médicos quase dobraram durante o período de 1914 e 1927.

Nessa mesma época, surgiram os novos estilos de hospitais, os chamados "white places" (lugares brancos, na tradução literal), onde se faziam cirurgias e partos. Esses ambientes foram projetados para oferecerem quartos individuais, com o apelo do conforto de apartamentos de hotéis e alta qualidade dos serviços prestados.

No período entre a Primeira e Segunda Guerras Mundiais, os serviços médicos começaram a concorrer com outros gastos como comida $e$ entretenimento, assim, manuais da época expunham que os médicos deveriam investir para atrair uma clientela pagadora por meio da decoração do consultório, boas maneiras e ligações para a casa dos pacientes, ou seja, tornar o ambiente agradável e criar um bom relacionamento com os pacientes. Nesse mesmo período, os serviços com saúde eram vistos como luxo, com os quais somente os mais ricos, que representavam cerca de um terço da população, poderiam arcar. 
A população do início do século $X X$ ainda experimentou uma obsessão por boa saúde, impulsionada em muito pelo desenvolvimento de novos produtos e apelo comercial. Desse modo, os americanos começaram a consumir mais e mais produtos relacionados à saúde, assim como livros com aconselhamentos sobre práticas saudáveis. Os gastos com remédios e tratamentos alternativos ou complementares (exemplo, quiropraxia) aumentaram, pois eram formas alternativas, menos especializadas e, portanto, mais baratas de manter boa saúde.

Documentos ainda revelam a insatisfação dos consumidores em relação aos serviços de saúde, principalmente as camadas medianas da sociedade, que não achavam que seu dinheiro estava sendo bem gasto com os tratamentos proporcionados pelos médicos, assim, eles buscavam médicos que os tratassem com respeito e fossem mais comunicativos. Além disso, surgiu o questionamento sobre o foco curativo da medicina ao invés da prevenção, e a indagação sobre o conflito de interesses com a indústria farmacêutica. Esses achados demostram que os profissionais da época, não viam a medicina como um serviço e ainda a pouca visão de negócios que os profissionais tinham de suas atividades profissionais.

\subsubsection{Conhecimento e aplicação de gestão por cirurgiões-dentistas}

Os trabalhos neste âmbito, embora não raros, são superficiais, geralmente mais qualitativos do que quantitativos e em sua maioria focam apenas um dos inúmeros aspectos do marketing: a propaganda/divulgação dos serviços. Desta forma, o panorama geral do conhecimento e a aplicação de conceitos de gestão apresentados nesta revisão permeará frequentemente somente esse aspecto.

Em um levantamento realizado com profissionais da área da saúde da Pensilvânia, nos EUA, o autor constatou que, apesar da literatura explicar e definir a propaganda como sendo um dos aspectos do marketing, que possui um significado mais amplo dentro de uma empresa/organização, muitos médicos concordaram, erroneamente, que anúncio/divulgação é um sinônimo de marketing (Folland,1987). 
Para comprovar as observações empíricas que tinham acerca da ineficiência da gestão financeira na Odontologia, Oliveira e Oliveira Jr. (1999) abordaram 61 cirurgiões-dentistas com a seguinte questão: "Em relação aos seus custos discrimine":

- gastos médios mensais;

- quantas horas trabalha ao mês;

- qual salário gostaria de ganhar;

- quanto cobra por uma restauração 3 faces de amálgama;

- quanto tempo demora para realizá-la;

- se trabalha com convênio, quanto o convênio Ihe paga pelo serviço acima;

- você tem mais pacientes de convênio ou particular.

Baseados nas respostas a essas perguntas, os autores concluíram que $42,62 \%$ dos cirurgiões-dentistas demonstraram não ter conhecimentos básicos para o cálculo adequado de seus honorários, pois não responderam todas as perguntas. Dos entrevistados, $57,38 \%$ responderam todas as perguntas, entretanto, uma análise mais profunda dos autores revelou que, embora tivessem uma noção de seus custos, os profissionais da amostra não conheciam o valor real de suas situações financeiras.

Em um levantamento com cirurgiões-dentistas norte-americanos realizado por Yavas e Riecken (2001), observou-se que as Páginas Amarelas, tradicional lista telefônica de empresas e serviços reconhecida mundialmente pela cor de suas páginas, eram utilizadas por $86 \%$ dos profissionais entrevistados, como forma de divulgação dos seus serviços.

Dentro do âmbito do marketing e da gestão, não é somente na gestão financeira que os cirurgiões-dentistas possuem dificuldades. Nakama et al. (2004) realizaram um levantamento para observar como os profissionais que atuavam na área da ortodontia se comportavam na primeira consulta com o paciente e quais artifícios usavam para promover a venda de seus serviços. Constatou-se que, dos 63 profissionais que responderam o questionário, 15,9\% falavam aos clientes sobre suas qualificações profissionais, $11,1 \%$ sobre as instalações de suas clínicas/consultórios, $6,3 \%$ sobre os equipamentos utilizados no tratamento, $25,0 \%$ sobre os materiais utilizados, $31,7 \%$ abordavam o funcionamento da 
clínica, mais de 90,0\% discorriam sobre documentação e o pré-diagnóstico, $20,7 \%$ sobre aspectos da biossegurança. Ainda, $57,1 \%$ afirmaram não realizar nenhuma ação, como envio de algum e-mail ou telefonema, após a primeira consulta, demostrando a falta de uma estratégia.

Também em 2004, Garcia e Cobra (2004) realizaram um levantamento sobre o perfil de trabalho dos cirurgiões-dentistas credenciados em convênios odontológicos. Mais da metade da mostra era composta por homens, até 35 anos de idade, sem título de especialista. Dos 150 respondentes de um questionário estruturado para esse estudo, $23,4 \%$ não souberem responder qual a porcentagem paga pelos convênios referente ao valor do tratamento.

Por sua vez, Garcia et al. (2005) também avaliou o comportamento de cirurgiões-dentistas atuantes em consultório particular durante a primeira consulta. Os respondentes em sua grande maioria residiam em São Paulo. Segundo os resultados obtidos a partir de um questionário administrado pelos pesquisadores, quase a metade dos cirurgiões-dentistas fazem o primeiro contato com o paciente na sala da recepção, e $35,4 \%$ relataram que o faz na sala clínica. Para convencer o paciente da necessidade do tratamento odontológico, verificouse que os profissionais usam a questão da função $(78,3 \%)$, prevenção de doenças $(76,1 \%)$, estética $(60,4)$ e controle da dor $(43,7 \%)$ como os principais argumentos. Apenas $5,4 \%$ dos profissionais relataram que a primeira consulta possui de 61 a 90 minutos de duração, sendo que $40,1 \%$ dos entrevistados relataram que, em média, a primeira consulta possui duração de até 30 minutos. Ainda, $71,5 \%$ realizam o orçamento do tratamento, e apenas $38,6 \%$ realizam o exame radiográfico durante essa consulta. Em relação aos recursos tecnológicos para auxiliá-los no processo de explicação do tratamento, $73,3 \%$ mostram ao paciente a situação de sua condição bucal, por meio de um espelho; $68,9 \%$ usam apenas a comunicação verbal, sem nenhum outro recurso; 49,8\% usam macromodelos e $22,7 \%$ usam atlas. Vídeos, computador, slide, ficha clínica, book com casos antigos e fotos de antes e depois apareceram na pesquisa com menor frequência.

Em um trabalho conduzido por Serra et al. (2005), foram analisadas as atitudes relativas ao uso de propaganda e outras ferramentas de marketing de 975 cirurgiões-dentistas, através da aplicação de questionários. Constatou-se que $39 \%$ dos entrevistados não faziam propaganda de seus serviços, $26 \%$ enviavam 
mala direta, $31 \%$ utilizavam uniforme padronizado para a equipe de trabalho e $22 \%$ dos cirurgiões-dentistas tinham o hábito de anotarem nos prontuários de seus pacientes temas não clínicos, que poderiam ajudar a conduzir conversas e criar um relacionamento com os pacientes. Os autores concluíram que os cirurgiões-dentistas empregam poucos recursos permitidos pelo Conselho Federal de Odontologia, e algumas ferramentas não estão sendo utilizadas adequadamente.

Para conhecer a importância percebida e o uso de conteúdos de contabilidade por cirurgiões-dentistas, Oliveira (2005) conduziu um estudo com alunos de cursos de pós-graduação da Universidade Paulista (UNIP) e Fundação para o Desenvolvimento Científico e Tecnológico da Odontologia (FUNECTO) em diversas áreas odontológicas. O número total de respondentes foi 200 , sendo que a maioria residia em São Paulo, eram formados a partir de 2001 e atuavam principalmente como clínicos gerais. Os resultados mostram que os cirurgiõesdentistas atribuem importância máxima para o controle de contas a pagar e a receber, assim como reconhecem como relevantes o conhecimento dos conteúdos de contabilidade e finanças para seu desempenho profissional. A maioria concorda parcialmente quanto à separação da conta corrente do consultório e a pessoal e projetou valores para custos fixos e variáveis para o próximo ano. Dos $34,5 \%$ que possuem um sistema informatizado para auxiliar na gestão do consultório, apenas $12 \%$ usam os módulos financeiros.

Arcier et al. (2007), por sua vez, estudaram 80 profissionais atuantes em consultórios particulares da cidade de São Bernardo do Campo, São Paulo, e constataram que $97,5 \%$ dos entrevistados recebem pacientes indicados por meio do boca a boca, $85 \%$ utiliza um modo organizado para o retorno dos pacientes, $71,3 \%$ utilizam logomarcas para personalizar a documentação do seu consultório. Cerca de $82 \%$ dos profissionais pesquisados confirmaram que suas secretárias e auxiliares trabalham uniformizadas e $87,7 \%$ afirmaram que a equipe receberam informações sobre o relacionamento profissional com os pacientes.

Em um levantamento com egressos do curso de odontologia da Universidade de Campinas entre os anos de 1998 e 2006, Mialhe et al. (2008), relataram que mais da metade da amostra $(62,85 \%)$ relataram que não gostam da parte administrativa da profissão.

Clow et al. (2007) descobriram em seu estudo realizado nos EUA que 
$71,5 \%$ dos cirurgiões-dentistas entrevistados possuíam websites, 67,7\% anunciavam nas Páginas Amarelas, 57,7\% possuíam folders para promover serviços e $46,7 \%$ anunciavam em jornais. Um dado interessante deste estudo foi a investigação sobre os meios pelos quais os pacientes procuravam os cirurgiõesdentistas, e foi observado que apenas $11,7 \%$ acessam seus websites, enquanto $74,4 \%$ procuravam em Páginas Amarelas e $47,2 \%$ nos jornais.

Em seu estudo exploratório-descritivo, Ribas et al. (2010) entrevistaram profissionais da região de Lages, Santa Catarina, para identificar como os profissionais que atendem no âmbito particular administravam seus consultórios. A amostra foi composta por $63,63 \%$ de profissionais formados por universidades federais, sendo $81,81 \%$ homens. Cerca de $36 \%$ dos profissionais iniciaram suas atividades profissionais em consultório próprio. A maioria afirmou que buscam conhecimento de organização e estratégias competitivas em revistas, softwares de gerenciamento de consultório e em conversas com amigos e parentes. Os autores relatam que a falta de controle financeiro é unânime e que a maioria dos entrevistados tratam a gestão do consultório e a odontologia separadamente, e não de uma forma sistêmica. Toda a amostra concordou quanto à importância do conhecimento de gestão para a área da saúde e que seria importante obter esse conhecimento na graduação.

Zuchini et al. (2012) analisaram 52 cirurgiões-dentistas atuantes nos municípios de Maringá e Marialva (Paraná). Para isso, utilizaram um questionário composto por questões abertas que continham variáveis relacionadas ao "perfil profissional" e ao "conhecimento" e "atuação" dos profissionais em marketing. Verificou-se que $77 \%$ dos cirurgiões-dentistas entrevistados já ouviram falar de marketing odontológico, entretanto, os autores notaram que esse conhecimento era incipiente. Mais da metade da amostra informaram que não utiliza estratégias de marketing, mas, dos que utilizavam algum recurso de marketing, o uso de folders ou folhetos informativos foi a principal ação relatada.

É importante ressaltar também que todas as práticas de marketing na odontologia, incluindo as ações de propaganda e publicidade, on-line ou off-line, devem obedecer ao Código de Ética da Odontologia. Entretanto, embora esse assunto seja abordado na grade curricular, estudos mostram que muitos profissionais brasileiros desconhecem e muitas vezes infringem as normas impostas pelo Conselho Federal de Odontologia (Garcia; Caetano, 2008; Oliveira 
et al., 2008; Martins et al., 2012; Rovida et al., 2012; Pena et al., 2013; Sassi et al., 2013).

\subsubsection{Atitude de paciente e profissionais da área da saúde quanto às práticas de marketing}

Ainda pode ser experimentado um certo preconceito diante da aplicação de ferramentas de marketing e gestão por parte dos profissionais da saúde, sobretudo por causa do caráter histórico das profissões dessa área. Desta forma, alguns estudos foram desenvolvidos para elucidar a atitude dos profissionais da área da saúde e também dos pacientes quanto aos anúncios e à divulgação dos serviços em Odontologia.

A maioria dos estudos aconteceu nos EUA, após o caso conhecido como Bates v. State Bar of Arizona em 1977 (O'Steen, 2005), quando o supremo tribunal do Arizona estabeleceu que a restrição à propaganda violava a primeira emenda da Constituição, a qual assegurava o direto ao livre discurso. Assim, em 1979, a American Dental Association (ADA) removeu a restrição aos anúncios para a Odontologia, o que foi controverso e bastante questionado pelos profissionais.

Em geral, os estudos mais antigos sobre a atitude de médicos e cirurgiõesdentistas, especificamente sobre anúncios, mostram que os profissionais eram pouco favoráveis ou até contra essa prática (Busson; Darling, 1978; Allen et al., 1985).

Em uma investigação de 1987 (Folland, 1987), constatou-se que a maioria dos 380 médicos estudados no estado da Pensilvânia, EUA, era relutante quanto aos anúncios e também pessimista em relação ao efeito dessa prática, pois achava que poderia prejudicar a imagem do profissional.

Lim e Zallocco (1998) descobriram que anúncios de hospitais, mesmo quando estes promoviam seu corpo clínico, foram mais bem aceitos pelos comunicadores de serviços de saúde do que anúncios de médicos.

Autores afirmam que os profissionais da área de saúde estão tendo uma atitude mais positiva em relação à divulgação de seus serviços e que essa é uma tendência para os profissionais mais jovens (Yavas; Riecken, 2001). 
Hite et al. (1988) realizaram um levantamento, comparando os resultados de um estudo sobre a atitude de profissionais e consumidores diante de anúncios de serviços odontológicos. Notou-se que os consumidores possuem uma atitude mais positiva em relação à divulgação dos serviços por meio de anúncios e, inclusive, encorajam os cirurgiões-dentistas a praticarem essa forma de divulgação, pois não acham que denigrem, prejudicam ou diminuem a credibilidade, ao contrário do que pensam os próprios profissionais questionados nesse levantamento. Esses dados vão ao encontro dos achados de Pickett et al. (1992), que observaram que os consumidores consideraram os anúncios formas úteis de procurar e decidir por um profissional de saúde.

Vinte anos depois do estudo de Hite et al. (1988), Clow et al. (2007) confrontaram os resultados, refazendo a metodologia empregada, e constataram que os profissionais estão um pouco mais abertos a esse tipo de divulgação, e os consumidores continuam mantendo suas atitudes positivas, mostrando que esses dois grupos estudados ainda possuem diferentes visões quanto ao assunto e seu impacto. Também é possível perceber pelos relatos dos pacientes que o relacionamento com os profissionais que cuidam de sua saúde não é realizado por meio de anúncios, e estes serviam apenas para guiar suas buscas por um professional.

Moser (2008), quis investigar a atitude dos pacientes em relação à promoção dos serviços profissionais de cirurgiões-dentistas por meio de anúncio. Com base na resposta de 404 consumidores de diversas cidades do estado norteamericano do Tenesse, o autor constatou que $51,9 \%$ dos respondentes não consideram que os anúncios diminuem a credibilidade e a dignidades dos profissionais. Ainda, quando questionados se usariam os serviços de cirurgiõesdentistas que se anunciam, $60,9 \%$ se mostraram favoráveis.

Com o objetivo de buscar os motivos de satisfação e insatisfação, Garbin et al. (2008b) entrevistaram 20 profissionais de Rio das Pedras, São Paulo. Foi observado, por meio de um questionário e de uma análise categórica das respostas, que os cirurgiões-dentistas entrevistados não tinham o hábito de transmitir informações acerca do tratamento para os pacientes. Tal fato, como observaram os autores, leva a frequentes relatos de insatisfação por parte dos pacientes, podendo ainda, em uma análise mais profunda, ser motivo de um processo judicial. 
Esse questionamento também esteve presente em um estudo realizado com cirurgiões-dentistas na Índia (Dable et al., 2011), cujo resultado revelou que os jovens profissionais do sexo masculino aprovam o uso de anúncios para a promoção dos serviços odontológicos, enquanto os profissionais mais velhos são contra o uso dessa mídia.

Mais recentemente, em 2012, os autores Kühnen e Ribeiro (2012) realizaram um questionário com perguntas baseadas nos 4 P's do Marketing: praça, preço, promoção e produto. Para o item praça, demonstrou-se que 27,8\% das 138 clínicas incluídas no estudo possuíam comunicação visual, 31,1\% possuíam estacionamento e $87,8 \%$ dos responsáveis técnicos pelas clínicas alegaram não terem feito pesquisa de mercado para a escolha do local. No quesito preço, 96,7\% das clínicas ofereciam parcelamento do valor do tratamento, $70 \%$ desconto à vista e apenas $35 \%$ trabalhavam com cartão de débito ou crédito. Quando o assunto era promoção, $23,3 \%$ declararam que não realizam nenhum tipo de propaganda, e a maioria confundia o conceito de marketing com o de propaganda.

Da amostra analisada, 94,4\% disseram que confirmam consulta do paciente, evitando assim faltas. Apesar de ter sido levantado que $87,8 \%$ dos funcionários usavam uniforme, apenas $38,9 \%$ dos responsáveis técnicos responderam que deram treinamento para a equipe. Para o produto, apenas $23 \%$ ofereciam garantia do tratamento, embora esse seja um direito garantido pelo Código de Defesa do Consumidor. Esse estudo ainda revela que 42,2\% dos cirurgiões-dentistas responsáveis técnicos pelas clínicas estudadas alegaram desconhecer o Código de Ética Odontológica que rege, entre outros aspectos da profissão, a propaganda e a publicidade na Odontologia.

Um dos assuntos mais em voga no marketing atualmente é, com certeza, o uso de redes sociais pelas empresas, que compõem o $\mathrm{P}$ do Marketing de promoção. Tanto que estudos sobre o uso dessas redes por profissionais da área da saúde também começaram a ser publicados. Em um levantamento de Wheeler et al. (2011), foi constatado que dos 1000 cirurgiões-plásticos entrevistados, quase metade $(46,7 \%)$ acessava sites de redes sociais para fins pessoais, enquanto $28,2 \%$ faziam uso para fins profissionais. Usher (2011) descobriu que de 935 profissionais da área da saúde da Austrália, 38,3\% possuíam conta no Facebook, e apenas 9,5\% usavam mídias sociais com finalidade profissional. 
Em um levantamento com 100 cirurgiões-dentistas dos Emirados Árabes Unidos, constatou-se que $87 \%$ dos profissionais não achavam que as redes sociais eram mídias sérias para promoverem seus serviços, e $50 \%$ não via potencial no uso dessas redes para promoverem seus serviços. A maioria usava essas redes sociais para fins pessoais (Rajan et al., 2011).

Os dados encontrados por Henry et al. (2012) mostram que os profissionais norte-americanos possuem uma visão sobre redes sociais mais aberta. Dos 573 respondentes de um questionário, $51 \%$ alegaram que usam principalmente o Facebook e desses $97 \%$ o usam profissionalmente, sendo $91 \%$ para fins de marketing, $73 \%$ para a comunicação com paciente e $73 \%$ para possuir melhor presença on-line.

$\mathrm{Na}$ vanguarda da temática na área odontológica, Goetz et al. (2014) estudaram consultórios odontológicos que receberam uma certificação em um programa de gestão da qualidade, que tem por objetivo reduzir eventos adversos, otimizar a eficiência do serviço e melhorar a satisfação do paciente. O processo de certificação envolve a avaliação de indicadores internos e externos validados, como a pesquisa de satisfação com os usuários e com a equipe de trabalho, uma acreditação formal por uma empresa externa, uma visita de um facilitador treinado, feedbacks estruturados e uma reunião com a equipe (Engels et al., 2006). Os domínios acessados neste processo são: infraestrutura, finanças, qualidade/segurança, pessoas e informação. Para o estudo, foram selecionadas clínicas odontológicas na Alemanha que iam passar pelo processo de certificação e clínicas que já haviam passado pelo processo e estavam renovando a certificação. Neste estudo, foi constatado que as clínicas que já haviam recebido a certificação no passado mantinham um melhor padrão de qualidade quando comparadas às clínicas que não tinham certificação. 


\subsubsection{Percepção e expectativas dos pacientes em relação aos serviços odontológicos}

Um dos objetivos do marketing é atrair e manter os clientes por meio de sua alta satisfação com o serviço prestado. Nesse sentido, conhecer o que os consumidores querem, bem como as formas para satisfazer suas necessidades é de extrema importância para o sucesso de uma prestação de serviço, uma vez que pacientes insatisfeitos buscam novos profissionais (Holt; McHugh, 1997).

Clow et al. (1994), após coletar informações de 240 famílias, concluíram que a qualidade sobre um serviço pode ser experimentada pelo cliente se este tiver suas expectativas alcançadas. Descobriram ainda que a imagem que 0 paciente tem do dentista pode influenciar suas expectativas em consultas futuras, assim como o nível de satisfação experimentado em consultas passadas influencia a expectativa para o futuro consumo do serviço, bem como o seu nível de qualidade.

A qualidade do serviço é influenciada, antes, por todo o seu processo de entrega, do que pelo resultado final. Como são incapazes de avaliarem tecnicamente um serviço, os pacientes focam em insatisfações durante a entrega do serviço, como, por exemplo, o fato de sentir dor. As pistas tangíveis (o que os pacientes podem olhar, sentir, cheirar ou ouvir) percebidas durante experiências passadas possuem efeito direto na construção da expectativa para futuras experiências de consumo, assim, a decoração, os aparelhos e equipamentos, aparência da equipe e limpeza possuem importante papel na construção da expectativa da qualidade do serviço pelo paciente.

Observou-se também que anúncios não mudam a imagem que o paciente tem do dentista. Assim, os autores afirmam que os profissionais podem mudar processos e condutas para irem ao encontro do que os pacientes desejam, modular a expectativa do cliente ou ainda trabalhar esses dois fatores juntos.

Em um estudo tipo survey, Rankin e Harris (1985) concluíram que os pacientes são sensíveis ao comportamento dos cirurgiões-dentistas e que, se estes se comportarem de acordo com o que os seus pacientes esperam, proporcionarão mais conforto, fazendo com que o tratamento dental seja um experiência positiva. Como o dentista também é sensível ao comportamento de 
seus pacientes, estes, quando satisfeitos, podem tornar a prática da odontologia menos estressante e mais recompensadora para o profissional.

No estudo conduzido por Holt e McHugh (1997), foi analisada a satisfação de 1003 pacientes de 13 clínicas do Reino Unido, por meio de um questionário. Os autores constataram que a atenção e o cuidado que 0 profissional oferecia ao paciente foi considerado muito importante por $90 \%$ dos respondentes. Mais de $70 \%$ dos pacientes consideraram como pontos importantes: o controle da dor, a explicação do tratamento, e o fato de o dentista deixar o paciente à vontade. Assim, os atributos mais impactantes na satisfação do paciente estão relacionados à atenção que o dentista lhe oferece, bem como sua capacidade de comunicação.

Em sua revisão de literatura, Newsome e Wright (1999), analisaram 45 estudos sobre satisfação do paciente odontológico. Dentre os itens mais encontrados como impactantes para a satisfação estão: as competências técnicas do profissional, fatores interpessoais, conveniência, custos e facilidades. Foram encontrados também dois principais instrumentos para acessar a satisfação dos pacientes em relação ao serviço odontológico: Dental Satisfaction Questionnaire (DSQ) e Dental Visit Satisfaction Scale (DVSS), propostos por Davies e Ware Jr. (1981) e Corah et al. (1984), respectivamente.

Para buscar entender as expectativas de pacientes que eram atendidos na clínica da Universidade de Atenas, na Grécia, Karydis et al. (2001) estudaram a resposta de 200 pacientes que elencaram como as principais expectativas: aderência às regras de assepsia e esterilização, uso de luvas, exame cuidadoso, diagnóstico correto e informações acerca de seus problemas, bem como do tratamento. A comunicação com o paciente também foi considerada como um fator de influência na satisfação do paciente, em um estudo de 2003, conduzido por Schouten et al. (2003), cuja conclusão foi que os cirurgiões-dentistas deveriam ser treinados para desenvolverem habilidades de comunicação.

Anderson (2004) estudou a expectativa dos pacientes em relação à tratamentos de urgência, ou seja, que envolvem dor. Foram entrevistados 44 pacientes que procuraram o serviço de urgência de clínicas de Wales, Reino Unido. A expectativa primária era o alívio da dor, mas também buscavam entender a causa de seu problema, em outras palavras, buscavam também respostas para os seus anseios que demandam atenção e a interação com o 
dentista, não somente o ato mecânico de remover a dor com um tratamento de canal ou extração.

Garbin et al. (2008a) entrevistaram 112 pessoas do município de Araraquara por meio de um formulário semiestruturado, com perguntas abertas e fechadas para investigar o motivo da escolha de um serviço privado em detrimento de um serviço público. Os resultados indicaram que para $9,1 \%$ dos pacientes o motivo foi devido à facilidade de acesso; para $19,1 \%$ foi devido à rapidez no atendimento/agendamento da consulta; para $10,1 \%$ foi devido à percepção de maior qualidade no serviço particular; para 7,7\% o uso de serviço particular se deu por não cobertura do tratamento necessitado pelo Sistema Único de Saúde (SUS); para 5,6\% foi devido à qualidade do serviço e materiais utilizados; 4,4\% afirmaram que confiam mais no profissional autônomo; e para $34 \%$ por outros motivos como "urgência" ou "hábito". Ainda, a maioria dos entrevistados afirmaram que a idade ou gênero do cirurgião-dentista não tem importância ou são pouco importantes na escolha do profissional e o uso de Equipamentos de Proteção Individual (EPIs) são muito importantes ou importantes.

Quando questionados sobre aspectos relevantes para a escolha do profissional, os pacientes afirmaram que a humanização (55,4\%), assim como o bom trabalho técnico $(23,3 \%)$ e boa higiene $(6,8 \%)$ são levados mais em consideração do que um bom preço (1\%), um ambiente agradável $(4,9 \%)$ ou o cumprimento de horário $(2,9 \%)$. Entretanto, problemas com este último item aparece como sendo um dos fatores que mais desagradam os pacientes $(19,45 \%)$ quando procuram um tratamento odontológico, seguido de barulho do motor $(9,7 \%)$ e problemas com humanização $(8,7 \%)$.

Furnham e Swami (2009) analisaram a resposta de 257 britânicos em relação a suas preferências por atributos como sexo, idade e local de treinamento do dentista. Assim, foi apresentada aos participantes da pesquisa uma situação hipotética de necessidade de um tratamento odontológico com diversas opções de profissionais que eles poderiam escolher. Os resultados mostraram associação entre idade e local de formação. Para os profissionais com formação na Europa, os respondentes da pesquisa preferiam os com menor idade, já para os profissionais com formação na Ásia, os paciente preferiam os de maior idade. Ainda, o sexo do dentista não pareceu importar na escolha do profissional. 
Klann et al. (2011) analisaram 74 clínicas odontológicas de Florianópolis, por meio de um questionário administrado para cirurgiões-dentistas e pacientes. Com a análise de dados, os autores concluíram que para os cirurgiões-dentistas os pontos assinalados como indispensável foram: tratar com respeito o paciente $(92,7 \%)$, examinar bem antes de concluir o diagnóstico $(89,3 \%)$ e o profissional deve ouvir o paciente $(87,3 \%)$.

$\mathrm{Na}$ escala dos fatores importantes, foram assinalados os seguintes pontos: o profissional raramente deve fazer o paciente esperar $(55,7 \%)$, o dentista deve estar disponível para uma urgência $(54,7 \%)$ e deve estar atualizado com a tecnologia odontológica $(48,7 \%)$. Como itens pouco importantes, foram assinalados que o profissional deve focar no paciente e não priorizar conversas com funcionários $(37,2 \%)$. Já para os pacientes, a maioria $(53,1 \%)$ afirmou que é indispensável o dentista ter disponibilidade de atender uma urgência, assim como estar atualizado em relação às tecnologias $(51,6 \%)$.

O estudo ainda concluiu que, para aumentar a satisfação do paciente, os cirurgiões-dentistas não devem demostrar como prioridade o dinheiro, e sim o atendimento; o professional deve focar no paciente, evitando priorizar conversas com funcionários; e deve aumentar a distribuição de folhetos explicativos, uma vez que os pacientes classificaram esse item como mais importante.

Com o objetivo de identificar as principais qualidades que um dentista precisa ter na opinião de um grupo de adultos, Collet et al. (2011) utilizaram a técnica da associação livre de palavras, cuja questão indutora foi a seguinte pergunta: "No seu entender, quais são as qualidades essenciais a um cirurgiãodentista?". Foram analisadas as respostas de 117 consumidores de serviços odontológicos de Balneário Camboriú/SC e constatou-se que os entrevistados buscam uma boa relação paciente-profissional $(32,1 \%)$, seguida de boas habilidades e competências técnicas $(29,4 \%)$. Itens como ética, cuidados de biossegurança e preço adequado foram lembrados com menor frequência $(8,2 \%$, $8,0 \%$ e $6,8 \%$, respectivamente). 


\subsubsection{Currículo nas faculdades de odontologia e perfil dos alunos e egressos}

O ensino da Odontologia no Brasil é regido pelas Diretrizes Curriculares Nacionais, que estabelecem os princípios e fundamentos, além de condições e procedimentos para a formação dos cirurgiões-dentistas brasileiros. Dentre as competências e habilidades que devem permear a formação dos profissionais, estão: atenção à saúde, tomada de decisão, comunicação, liderança, administração e gerenciamento e educação permanente.

No inciso V, referente ao quesito "administração e gerenciamento", o documento prevê (CNE, 2001, p. 1 e 2):

Art. $4^{\circ} \mathrm{A}$ formação do cirurgião-dentista tem por objetivo dotar o profissional de conhecimentos requeridos para o exercício das seguintes competências e habilidades gerais:

(...)

V- Administração e gerenciamento: os profissionais devem estar aptos a tomar iniciativas, fazer o gerenciamento e administração tanto da força de trabalho, dos recursos físicos e materiais e de informação, da mesma forma que devem estar aptos a serem empreendedores, gestores, empregadores ou lideranças na equipe de saúde.

Nesse sentido, vários levantamentos com estudantes de Odontologia mostram que a expectativa em relação à inserção no mercado é ter um consultório próprio e essa vontade é realizada muitas vezes, como comprovam os estudos sobre a vida profissional dos egressos das universidades.

Surgiram também muitos autores questionando a lacuna do ensino ao preparar esses profissionais para atingirem esse objetivo, como defendia Richardson (1976), que preconizou o ensino da gestão em saúde para complementar a formação do profissional.

Oliveira e Oliveira Jr. (1999) questionaram 61 cirurgiões-dentistas se o curso de graduação os havia preparado para o mercado de trabalho. Cerca de $75 \%$ consideram que a faculdade proporcionou preparo adequado, embora uma análise mais profunda tenha demonstrado que eles estavam considerando apenas o conhecimento técnico-cientifico, como carga horária, treinamento de habilidades e qualidade dos professores. Os $24,60 \%$ que não consideram a graduação adequada neste aspecto argumentaram justamente que o foco do 
conteúdo é extremamente técnico, não sendo o suficiente para enfrentar o mercado de trabalho.

Para conhecer o perfil dos alunos do curso de Odontologia da Universidade do Rio Grande do Sul, de 1998 a 2001, Slavutzky et al. (2002) elaborou um questionário que foi respondido por 166 acadêmicos. O principal motivo que levou os alunos do $6^{\circ}$ semestre a escolherem a profissão foi por ela ter uma característica liberal. Cerca de $60 \%$ afirmou ainda que buscam, com a profissão, a satisfação profissional, sendo que apenas $10 \%$ relatou que busca uma remuneração adequada. Quando questionados sobre onde pensavam em trabalhar logo após a formatura, $57 \%$ respondeu que buscam consultório próprio individual, compartilhado ou clínica própria compartilhada. Quase 30\% disseram que buscavam o serviço público.

Em um levantamento com egressos da Faculdade de Odontologia da Universidade de São Paulo entre os anos de 1990 a 1998, com uma amostra de 320 profissionais, foi constatado que, dos 172 cirurgiões-dentistas que responderam o questionário, 50,16\% possuíam consultório próprio, sendo que nos primeiros anos de carreira a principal forma de inserção no mercado de trabalho foi o trabalho por porcentagem em consultórios odontológicos de terceiros (Crosato, 2003).

Um levantamento com amostra formada por 98 cirurgiões-dentistas formados pela Faculdade de Odontologia de Bauru, entre os anos de 1996 e 2000 , constatou que $38,8 \%$ dos egressos possuem consultório próprio e $25,5 \%$ trabalham por porcentagem em consultório de terceiros. Quando solicitado que listassem as cinco maiores dificuldades no exercício da profissão, o item mais votado foi a competitividade do mercado de trabalho, sendo que a capacidade de saber administrar, gerenciar e ter noções de Marketing $(23,5 \%)$ apareceu como a segunda característica mais importante, necessária aos profissionais na atualidade, juntamente com ter conhecimento técnico-cientifico $(22,4 \%)$, que perde apenas para a atualização e o estudo constante $(32,7 \%)$ (Bastos et al., 2003).

Oliveira (2005) realizou um levantamento sobre aspectos financeiros dos cirurgiões-dentistas para conhecer o perfil dos profissionais nessa área. Participaram da pesquisa 2000 alunos de pós-graduação da UNIP e Fundação para o Desenvolvimento Científico e Tecnológico da Odontologia (FUNECTO). 
Cerca de $63 \%$ da amostra relataram que nunca participaram de nenhum curso, seminário ou palestra sobre Contabilidade, Finanças ou Administração de consultórios. Quanto a esse conteúdo no currículo da graduação, apenas 9,5\% afirmou ter tido contato com o conteúdo finanças, $11 \%$ com assuntos de contabilidade e $25 \%$ de administração. Filtrando-se a resposta para essa pergunta somente para alunos da Faculdade de Odontologia da USP, 8,3\% afirmaram que obtiveram conhecimento acerca de finanças na graduação, $13,3 \%$ de contabilidade e $21,7 \%$ sobre administração.

Com base em um questionário respondido por alunos do primeiro ao quarto ano e alunos egressos da Faculdade de Odontologia da Universidade de Taubaté, descobriu-se que a maioria dos alunos do primeiro ano possuem a expectativa de trabalhar em consultório próprio, seguido pelo desejo de trabalhar no setor público. Já para os alunos do quarto ano, essa relação se inverte, pois a maioria respondeu que gostaria de possuir um emprego público, seguido por possuir um consultório próprio. Os egressos formaram dois grupos: grupo 01, composto por formados nos anos de 1993 a 1995, e o grupo 02, composto por formados de 1998 a 2000. Para ambos os grupos, a principal forma de exercício da profissão era a atuação em consultório próprio, com cerca de $60 \%$ dos respondentes (Rezende et al., 2007).

Os alunos egressos da Faculdade de Odontologia da Faculdade de Piracicaba, do período de 1998 a 2006, em sua maioria com mais de 3 anos de formados, trabalhavam de forma autônoma (65,7\%), e 51\% sugeriram a inclusão ou maior carga horária de disciplinas de marketing, estratégias de abordagens de pacientes e administração do consultório, como parte da grade curricular. Ainda, $57 \%$ afirmam que os honorários recebidos não satisfazem suas necessidades próprias (Mialhe et al., 2008). Em um estudo com 100 cirurgiões-dentistas do sexo feminino de Araraquara, 57,7\% declaram-se como autônomas, 72\% trabalham somente em consultório/clinicas privadas e $64 \%$ da amostra informaram se tratar de consultório próprio (Moimaz, 2012).

Segundo Gorter et al. (2008) um dos motivos dos cirurgiões-dentistas não estarem preparados para o mercado de trabalho é a falta de conhecimento sobre gestão de recursos humanos e organização do consultório.

Ponte (2009) realizou um levantamento com profissionais atuantes do estado de São Paulo que revelou a grande importância dada pelos cirurgiões- 
dentistas aos conhecimentos de gestão para a prática clínica, sendo que 98,31\% afirmaram que valorizam o conhecimento de processos administrativos para gerir o consultório, clínicas e equipes e $89,4 \%$ expressam a vontade de ter maior conhecimento nas áreas de gestão de recursos humanos.

Para acessar o perfil do aluno da Faculdade Federal do Maranhão, Silva et al. (2011) aplicaram um questionário a 206 alunos matriculados na instituição e observou que $74,2 \%$ da amostra residiam no estado do Maranhão. A motivação pela procura do curso se deu por vocação, seguida por $26 \%$ que indicaram como motivação o fato de a odontologia ser uma profissão da área da saúde. Em relação aos seus planos para o futuro, 46,6\% pretendem trabalhar em consultório próprio, e 98,5\% pretendem fazer curso de pós-graduação, sendo que desses, $39.5 \%$ querem fazer especialização.

Ponte (2012) também questionou os alunos da Faculdade de Odontologia da Universidade de São Paulo sobre a expectativa em relação à inserção no mercado, e apenas $3,86 \%$ dos alunos afirmaram que nunca montariam consultório.

\subsection{SATISFAÇÃO PROFISSIONAL}

Segundo Locke (1969), a satisfação profissional está relacionada à relações emocionais complexas e envolve três aspectos da interação do homem com o meio ambiente: a sua percepção; os valores implícitos e explícitos; e o julgamento entre eles. $O$ julgamento entre a situação que o indivíduo está vivenciando (percepção) e a situação que esperava vivenciar (valores) decorrente da experiência de trabalho, pode resultar em uma sensação agradável/desagradável ou estado emocional positivo/negativo. A satisfação profissional ainda tem sido definida como o sentimento pessoal individual em relação à profissão e é associada a várias dimensões da atividade de trabalho relacionada (Kalleberg, 1977). A International Labor Organization (1984) ressalta que a satisfação profissional pode estar associada à motivação ou à atitude do individuo perante o trabalho, ou também pode ser resultado do ambiente de trabalho. 
Conforme definição de Nicolielo e Bastos (2002), a satisfação profissional é o resultado positivo no estado emocional do individuo derivado do prazer que se tem com as suas experiências no trabalho e é fortemente relacionada à fatores como desempenho profissional, qualidade de vida, saúde física e mental e com a autoestima do trabalhador. Kotliarenko (2005) entende que a satisfação profissional é o resultado da soma de fatores psicológicos e sociais que impactam diretamente o comportamento do homem dentro do exercício de sua profissão.

Por seu aspecto multidimensional, Herzberg et al. (1959), desenvolveram uma teoria de dois fatores para a satisfação profissional, que distingue o bem estar na esfera profissional entre fatores de motivação ou intrínsecos, representados pelas tarefas executadas, pelo reconhecimento e pela responsabilidade da atividade; e por fatores extrínsecos ou de higiene, representados por condições de trabalho e salário.

Além disso, diferentes estudos (Sur et al., 2004; Gilmour et al., 2005) mostram que a análise de satisfação profissional é multifatorial e que não pode se resumir a estar ou não estar satisfeito com a profissão, uma vez que aspectos específicos como valores individuais, expectativas, experiências vividas, entre outros, estão direta e fortemente relacionados à satisfação profissional.

Levando em consideração o seu caráter complexo, um dos instrumentos mais usados para acessar a satisfação profissional, o Dentist Satisfaction Survey (Shugars et al., 1991), foi desenvolvido com base em 10 questões gerais sobre satisfação e 44 itens para mensurar 11 aspectos da profissão, a saber: entrega de cuidados, relacionamento com paciente, percepção de renda, tempo pessoal, práticas de gestão, ambiente profissional, relações profissionais, tempo profissional, respeito, equipe e estresse. Wells e Winter (1999) concluíram em seu estudo que a satisfação profissional envolve 6 aspectos: o respeito percebido, a percepção de renda, o fornecimento de assistência, o estresse, as relações com o paciente e o tempo profissional, ou seja, carga horária de trabalho. Para a escala, entretanto, não há um padrão ouro para acessar a satisfação profissional em odontologia (Van Saane et al., 2003). 


\subsubsection{Satisfação profissional do cirurgião-dentista}

Esta seção foi dividida em duas subseções, separadas por critérios geográficos, por duas razões: pelo fato de a satisfação profissional ser influenciada por questões socioeconômicas, culturais; e pela realidade dos cirurgiões-dentistas brasileiros serem particulares, quando comparados a outros países devido sua formação e expectativas com a profissão.

\subsubsection{Satisfação dos cirurgiões-dentistas em diversos países}

Logan et al. (1997) constataram em seu estudo que 3 a cada 5 cirurgiõesdentistas da amostra estavam satisfeitos com a careira. Entretanto, embora a maioria dos profissionais entrevistados mantivesse uma atitude positiva em relação a profissão, estavam igualmente insatisfeitos com seu nível de estresse, com o ambiente de trabalho e com o tempo pessoal disponível.

Em 1999, Wells e Winter (1999) constataram, em uma amostra de 987 cirurgiões-dentistas do estado norte-americano do Kentucky, que itens como o reconhecimento recebido pela profissão e o fornecimento de assistência eram os mais fortes aspectos que resultavam na satisfação profissional, enquanto as operações administrativas, incluindo o planejamento financeiros, traziam insatisfação.

Para avaliar a satisfação profissional de 319 ortodontistas canadenses, Roth (2003), usou a escala DSS modificada para a aplicação na Ortodontia, contendo 10 itens sobre satisfação geral e 42 itens organizados para mensurar 10 aspectos da satisfação com a profissão. A média de satisfação geral foi de 4,02 $(\mathrm{DP}=0,63)$, sendo 1 completamente insatisfeito e 5 completamente satisfeito, mostrando que os ortodontistas incluídos na pesquisa estão satisfeitos.

Para as facetas do trabalhos foram encontradas as seguintes médias: 4,2 $(\mathrm{DP}=0,5)$ para relação com o paciente, 4,1 ( $\mathrm{DP}=0,5)$ para qualidade de vida geral, $4,1(\mathrm{DP}=0,6)$ para respeito, 4,0 (DP=0,5) para entrega de cuidados, 4,0 (DP=0,7) para relações profissionais, 3,9 $(\mathrm{DP}=0,7)$ para equipe, 3,8 $(\mathrm{DP}=0,9)$ para 
ambiente profissional, 3,7 (DP=0,8) para percepção de renda, 3,6 (DP=0,6) para tempo profissional, 3,4 (DP=0,7) para as práticas de gestão e 3,3 $(\mathrm{DP}=1,0)$ para tempo pessoal. Ainda, $85,3 \%$ afirmaram estarem satisfeitos ou muito satisfeitos com a carreira e $87,3 \%$ escolheriam novamente a ortodontia.

$\mathrm{Na}$ Turquia, país em que a odontologia é considerada uma profissão de prestígio e possui uma grande oportunidade do profissional atingir bons prólabores, Sur et al. (2004) conduziram um estudo de satisfação, usando a versão turca validada do Minnesota Satisfaction Questionnaire (MSQ) ou o Questionário de Satisfação de Minesota. Os resultados mostraram que 40,8\% da amostra, composta por cirurgiões-dentistas que trabalham em consultórios odontológicos privados, estavam satisfeitos com o trabalho. Os autores ainda concluíram que idade, pró-labore, presença de auxiliar e número de pacientes atendidos por dia impactam nos níveis de satisfação.

Para avaliar a satisfação profissional de cirurgiões-dentistas de uma cidade na Austrália, Luzzi et al. (2005) adaptaram um questionário usado por Williams et al. (1999) que incluíam 50 itens, sendo: 38 questões preditoras de satisfação, que incluíam entre outros aspectos, a autonomia, a relação com os colegas e membros da equipe, tempo pessoal, satisfação intrínseca, compensação; e 12 questões que mediam a satisfação profissional especificamente na Odontologia, baseada em três aspectos - satisfação geral, satisfação na carreira e satisfação com a área de especialização escolhida. A amostragem foi composta por 87 cirurgiões-dentistas, sendo que $58 \%$ trabalhavam em clínicas privadas, e 42\% em clínicas públicas. Dos respondentes, $82,6 \%$ demostraram médias maiores que 3 para a satisfação com as várias dimensões da prática odontológica. Para o questionário preditor de satisfação, as dimensões a que os cirurgiões-dentistas se mostraram menos satisfeitos foram com as responsabilidades administrativas e remuneração. Ainda, as maiores médias foram para os itens: autonomia, relação com colegas e membros da equipe e materiais Para as perguntas relacionadas com a satisfação na odontologia, cerca de $81 \%$ da amostra demostraram ter médias maiores que 3 , indicando satisfação profissional.

Jeong et al. (2006) sugere que o relacionamento com pacientes, a percepção de renda, o tempo pessoal disponível, a equipe e o treinamento especializado foram fatores importantes do ambiente de trabalho para a 
satisfação profissional.

Puriene et al. (2007) analisaram, por meio do DSS, a satisfação profissional de cirurgiões-dentistas da Lituânia. A amostra era composta por $85 \%$ de mulheres, e apenas $17,4 \%$ profissionais com título de especialidade. De uma escala de 1 a 5, a satisfação dos profissionais alcançou 4,06 pontos, mostrando que a população do estudo estava muito satisfeita com a profissão. Quando analisados os itens que compunham o instrumento, aspectos como seguridade social, percepção de renda, tempo pessoal e tempo com a família foram os que obtiveram os menores scores, enquanto relações profissionais e o relacionamento com os pacientes obtiveram as maiores pontuações.

Kelsey et al. (2009) estudou a satisfação profissional de egressos de 1985 a 2005 da universidade de Creighton, em Nebrasca, EUA, juntamente com a satisfação obtida com o ensino da graduação. Para mensurar a satisfação profissional, foram levados em conta aspectos da interação com os pacientes, como autonomia, educação continuada, compensação financeira, prestígio obtido pela profissão, responsabilidades profissionais, seleção/contratação de funcionários. Foram obtidos 485 questionários respondidos. Dos aspectos analisados de satisfação profissional, o que impactou na satisfação dos cirurgiões-dentistas estudados foi o item "interação com os pacientes". Ainda, em um ranking de satisfação com a preparação acadêmica que analisou 15 áreas da odontologia, a gestão e administração ficou em último lugar.

Para acessar a satisfação profissional de cirurgiões-dentistas formados na Universidade de Malmo, na Suécia, Bengmark et al. (2012) enviou um questionário via correio em 2002. A população do estudo foi composta por 128 profissionais, sendo $57 \%$ de mulheres, $97 \%$ ainda atuavam na área da Odontologia e $70 \%$ possuíam emprego no setor público somente. Usando uma escala VAS de 1 a 10, descobriu-se que $90 \%$ dos cirurgiões-dentistas suecos estavam satisfeitos com a situação atual de sua profissão, uma vez que $90 \%$ da amostra assinalaram scores entre 6 e 10. Os autores acharam também que os cirurgiões-dentistas que estavam mais satisfeitos com 0 ensino recebido possuíam maior satisfação com a profissão.

Em 2012, Oweis et al. (2012) realizaram uma pesquisa com cirurgiõesdentistas da Jordânia, que foram questionados sobre sua satisfação na profissão e se fariam odontologia novamente. Segundo o autor, o alto padrão social é um 
atrativo para a profissão no país. Dos 355 respondentes, $20 \%$ alegaram que estavam muito satisfeitos, $49 \%$ parcialmente satisfeitos, $13 \%$ não estavam muito satisfeitos e 7\% não estavam satisfeitos, os demais não souberam responder. Os maiores níveis de satisfação foram encontrados no grupo de profissionais com 30 a 49 anos. Ainda, 38\% responderam que fariam odontologia novamente e 52\% não fariam principalmente pelos problemas físicos que a profissão trouxe para sua saúde e os baixos salários. Os que escolheriam odontologia novamente levaram em consideração a oportunidade de trabalhar com pessoas e ajudar o próximo.

Também em 2012, Goetz et al. utilizaram a escala de 10 itens de WarrCook-Wall (WCW) para acessar a satisfação profissional de cirurgiões-dentistas proprietários de clínicas odontológicas particulares da Alemanha que buscavam uma certificação de qualidade concedida pelo Joint Committe, uma vez que satisfação profissional é um componente da avaliação destas certificações. Os cirurgiões-dentistas estudados eram na sua maioria homens, com média de 46 anos e jornada de trabalho de 39,9 horas semanais. Enquanto nas dimensões "liberdade com o método de trabalho" e "variedade do trabalho" os cirurgiõesdentistas estavam satisfeitos, os itens "salário" e "jornada de trabalho" geraram descontentamento.

Em um estudo comparando a satisfação profissional de cirurgiões-dentistas que atuam no setor público e privado da Suécia e Dinamarca, com amostra representativa da população desses dois países, Ordell et al. (2013) concluíram que os cirurgiões-dentistas suecos do setor público são os menos satisfeitos e os dinamarqueses os mais satisfeitos. Além disso, na Dinamarca, $76 \%$ dos cirurgiões-dentistas que exercem suas atividades no serviço privado possuem responsabilidades administrativas/gerenciais e $91 \%$ na Suécia.

Ao acessar a satisfação profissional de 227 cirurgiões-dentistas que trabalhavam em hospitais na área do canal de Suez, na região do Egito, Fahim (2013) usou o instrumento DSS e verificou o score de 3.24 para uma escala de 1 a 5, o que demonstra que os profissionais possuem uma relação neutra com a profissão, sendo que o tempo pessoal e profissional obtiveram os menores scores.

Estudando especificamente a odontopediatria dos EUA, Bates et al. (2013) realizaram uma pesquisa nacional com os cirurgiões-dentistas registrados na Academia Americana de Odontopediatria (American Academy of Pediatric 
Dentistry). Para acessar a satisfação profissional desse profissionais foram usadas 3 séries de questões. A primeira série era referente a coleta de dados sociodemográficos, a segunda série sobre características da prática odontológica individual e a terceira série sobre a satisfação profissional propriamente dita. Para essa última série foram usadas duas escalas, sendo elas:

- Escala de Satisfação Profissional (Profissional Satisfaction Scale) proposta por Shugerman et al. (2001), que possui 4 questões com possíveis respostas afirmativas (sim) e negativas (não), sendo elas: (a) Se pudesse voltar ao passado, teria escolhido odontologia novamente? (b) Se pudesse voltar ao passado, teria escolhido a especialização em odontopediatria novamente? (c) Você recomendaria a odontologia para os seus filhos? (d) Você recomendaria a especialização em odontopediatria para os seus filhos?;

- Escala de Satisfação para Cirurgiões-dentistas - DSS (Dentists' Satisfaction Survey), desenvolvida por Shugars et al. (1991) que originalmente compreende 54 questões, porém dessas questões foram selecionadas 39 que eram aplicáveis para a odontopediatria. As respostas possíveis eram de 1 a 5 , sendo que 1 indica baixa satisfação e 5 indica alta satisfação. A escala possui 10 séries compostas pelos seguintes temas: relação com o paciente, assistência, respeito percebido pela profissão, satisfação profissional geral, funcionários, tempo profissional, tempo pessoal, rendimentos financeiros, relação profissional e prática administrativa.

O estudo obteve 966 respondentes, com média de idade de 47,22 anos, sendo a maioria do sexo masculino. Para a primeira escala - Escala de Satisfação Profissional - os resultados encontrados foram: $89 \%$ escolheria novamente a odontologia, 92\% escolheria novamente a odontopediatria, $85 \%$ recomendaria a Odontologia para seus filhos e $83 \%$ recomendaria a odontopediatria para seus filhos. Para a segunda escala, a Escala de Satisfação para Cirurgiões-dentistas, as série que tiveram scores iguais ou maiores que 4 foram: relação com o paciente, assistência, respeito e satisfação profissional geral. Entre 3,5 e 4 ficaram as séries sobre funcionários, tempo pessoal e profissional, e rendimentos financeiros. Já os scores abaixo de 4 englobaram a relação profissional e a prática administrativa. 


\subsubsection{Satisfação profissional de cirurgiões-dentistas no Brasil}

Para cirurgiões-dentistas mulheres de Araçatuba, Moimaz et al. (2003) concluíram que, embora $58,2 \%$ dessas profissionais não indicassem que seus filhos cursassem Odontologia, $78 \%$ estavam satisfeitas com a profissão. Dentre os motivos de insatisfação relatados por 22 cirurgiões-dentistas que compunham a amostra de 100 profissionais, os autores destacaram que a questão financeira, a saturação do mercado de trabalho e a desvalorização do profissional foram os itens que mais impactaram.

Bastos et al. (2003) pesquisaram, por meio de um questionário, a satisfação profissional de cirurgiões-dentistas formados pela Faculdade de Odontologia de Bauru (FOB) - USP, entre os anos de 1996 e 2000, e constataram que mais da metade dos cirurgiões-dentistas responderam que, se hoje tivessem que optar por uma carreira, escolheriam novamente a Odontologia, ao passo que $37,8 \%$ escolheriam outras carreiras, dentre as quais se destacaram a Medicina, a Administração e a área de Exatas. Embora 63,3\% se sintam realizados profissionalmente, apenas $12,2 \%$ dos profissionais se sentem realizados financeiramente.

Um estudo acerca da vacinação contra a hepatite B entre cirurgiõesdentistas englobou a pergunta sobre satisfação com a profissão. Foram respondidos 296 questionários por cirurgiões-dentistas residentes em Montes Claros, Minas Gerais; verificou-se que cerca da metade da amostra era composta por mulheres, com média de 37 anos de idade e 12 de formadas, e $43 \%$ atendiam somente em consultório particular. Quanto à questão sobre satisfação, 50\% consideraram-se muito satisfeitos com a profissão, e $15 \%$ pouco satisfeitos (Martins; Barreto, 2003).

Em um levantamento realizado por Michel-Crosato et al. (2006), foi perguntado a 153 cirurgiões-dentistas do Meio Oeste do Brasil qual o nível de satisfação com a profissão. Os achados mostram que $83 \%$ dos entrevistados se sentem satisfeitos com a profissão, muito provavelmente, como relatam os autores, pelo reconhecimento de sua atividade recebido de seus pares. 
Para conhecer o perfil profissional de cirurgiões-dentistas que trabalhavam na rede publica da Prefeitura de São Paulo em 2007, Michel-Crosato (2008) traduziu e validou uma escala de satisfação profissional para a realidade brasileira modificada por Jeong et al. (2006) a partir da escala de Shugars et al. (1991), a mesma escala utilizada no presente estudo. Responderam o questionário 605 pessoas, e se verificou que o nível médio de satisfação foi de 2,86 ( $D P=0,20)$, em uma escala de 1 a 5 . Os valores médio para cada bloco foram de 2,84 para a satisfação geral com o trabalho/emprego, 2,77 para a percepção de renda, 2,82 para tempo pessoal, 2,78 para tempo profissional, 2,76 para equipe, 2,79 para relacionamento com o paciente e 3,20 para o quesito de fornecimento de assistência/atendimento.

Ao questionar alunos egressos de 1998 a 2006 da Faculdade de Odontologia de Piracicaba - Universidade de Campinas, em sua grande maioria com mais de 3 anos de formados no momento da pesquisa, Mialhe et al. (2008) observaram que, embora o prestígio recebido pela profissão, o orgulho e o respeito pela atuação profissional tenham sido experimentados pela amostra, $51,4 \%$ disseram que as suas aspirações enquanto estudantes não haviam sido concretizadas, e $57,2 \%$ também não tinham as aspirações atuais preenchidas pela odontologia.

De acordo com os resultados, $63 \%$ não encorajariam os filhos a seguirem a mesma profissão, $54,3 \%$ não teriam escolhido novamente a odontologia baseados na experiência pessoal. Ao exercer a odontologia, entretanto, $71,4 \%$ afirmam que essa é a área onde podem dar sua melhor contribuição. Os autores ainda concluem que os cirurgiões-dentistas entrevistados estavam insatisfeitos com alguns aspectos, como os honorários, porém a maioria sente orgulho com o exercício da profissão.

Gomes et al. (2010) verificou, em seu trabalho, a satisfação profissional e os motivos de estresse em profissionais da rede pública do município da grande Florianópolis - SC, cuja amostra era composta de 15 cirurgiões-dentistas atuantes em unidades básicas, e 15 profissionais participantes da Estratégia da Saúde da Família, que a assistência oferecida para o paciente e a satisfação com a profissão em si estavam presentes entre os profissionais entrevistados. Já os motivos de estresse relatados foram a excessiva carga de trabalho, uma vez que a maioria dos profissionais acumulavam atividades no âmbito particular. 
Ponte et al. (2011) buscaram elucidar se os profissionais que exerciam suas atividades no setor privado estavam satisfeitos. Para tal, foram convidados a responderem um questionário, 219 cirurgiões-dentistas que trabalhavam em uma empresa inserida no conceito social, que presta serviços à população no âmbito do bem-estar social por meio da promoção da saúde, e abrange o desenvolvimento de atividades na área de saúde, lazer, prática esportiva e cultura. A escala de satisfação utilizada foi validada por Michel-Crosato (2008).

Ao total 194 cirurgiões-dentistas responderam o instrumento, sendo que $68,04 \%$ eram do gênero feminino, $35,57 \%$ em faculdades particulares e $59,79 \%$ tinham um ou mais especializações. A média do nível de satisfação dos participantes dessa amostra foi de 3,45, considerando-se uma escala de 1 a 5 . Além disso, os profissionais que cursaram a graduação em faculdade pública obtiveram melhores níveis de satisfação. Quando os blocos foram analisados, observaram-se os seguintes valores médios: 3,39 para a satisfação geral com o trabalho/emprego, 3,21 para a percepção de renda, 2,60 para tempo pessoal, 3,13 para tempo profissional, 3,35 para equipe, 4,34 para relacionamento com o paciente e 4,16 para o quesito de fornecimento de assistência/atendimento.

Ao analisar a inserção dos 72 egressos do curso de Odontologia da Faculdade de Farmácia, Odontologia e Enfermagem da Universidade Federal do Ceará, formados em 2007, Pinheiro et al. (2011) validaram um questionário que continha, entre outros aspectos, a satisfação com a profissão escolhida. Com um total de 41 respondentes, os autores observaram as características da amostra: $78 \%$ eram do sexo feminino, entre 22 e 28 anos, mais da metade possuía renda mensal entre 3 a 5 salários-mínimos e trabalha entre 31 e 40 horas semanais, $40 \%$ possui emprego no setor público com contrato e $22 \%$ eram autônomos. Quanto ao mercado de trabalho, $41 \%$ afirmaram que o perceberam como bom, $36.6 \%$ como normal. Em relação à satisfação com a profissão escolhida, 82,9\% responderam estar satisfeitos com a escolha da profissão. 


\section{PROPOSIÇÃO}

São as propostas deste estudo:

\subsection{OBJETIVO GERAL}

Verificar se melhores práticas de gestão podem influenciar positivamente na satisfação profissional, dentro da área da odontologia.

\subsection{OBJETIVOS ESPECÍFICOS}

- Criar e validar uma escala-questionário para auto-avaliação sobre conhecimento e práticas de gestão para a área da odontologia;

- Identificar os indicadores críticos essenciais à gestão de consultórios odontológicos;

- Identificar a satisfação profissional da amostra. 


\section{MATERIAL E MÉTODOS}

\subsection{TIPO DE ESTUDO}

Transversal, descritivo e analítico, com dados obtidos a partir de três questionários.

\subsection{POPULAÇÃO DO ESTUDO}

Cirurgiões-dentistas brasileiros selecionados pelo método da conveniência.

\subsection{MÉTODOS}

Para o presente estudo, foram utilizados três questionários distintos: um questionário demográfico, um questionário desenvolvido e validado para esta pesquisa sobre conhecimentos de gestão/marketing e um questionário sobre satisfação profissional, já validado anteriormente por outro autor.

\subsubsection{Desenvolvimento e validação do DMS-BR}

Para a fase de desenvolvimento e validação da escala DMS-BR, foram realizadas três distintas etapas, estabelecidas em fases para melhor entendimento do leitor. 
4.3.1.1 Fase 01: desenvolvimento do questionário

O instrumento proposto foi desenvolvido com base na revisão da literatura sobre gestão e marketing, além de ter a validade do conteúdo analisada por uma banca de profissionais/pesquisadores experientes na área (Painel de experts da área), com profissionais que trabalham com marketing e gestão para a Odontologia.

Após concluída a primeira versão do questionário, iniciaram-se as auditorias em 10 (dez) consultórios odontológicos de cirurgiões-dentistas de São Paulo, Barueri e Osasco, que possuíam diferentes características (prédios comerciais, clínicas na rua, consultório com um sala de atendimento, clínicas com até 7 salas), com o objetivo de testar e reformular o instrumento em caso de necessidade. Esta fase foi realizada nos meses de março a maio de 2013.

Os cirurgiões-dentistas convidados a participar desta primeira fase da validação do instrumento (FASE 01) faziam parte do grupo de contato dos pesquisadores e foram avisados da pesquisa verbalmente. No caso de aceitação do convite, era marcada uma data para a visita e, na mesma oportunidade, era enviado o link contendo o questionário on-line que $\mathrm{o}$ participante deveria responder antes do dia marcado, a fim de evitar viés na escolha das respostas.

Durante a entrevista desta fase, os dados coletados eram anotados em uma ficha e depois comparados com as respostas colhidas no questionário online. $O$ objetivo dessa fase é verificar se há coerência com o que o participante respondeu no questionário on-line e na entrevista, momento no qual eram feitas perguntas mais aprofundadas e o participante tinha a chance de explicar suas respostas, demostrando seus conhecimentos e habilidades na área de gestão e marketing.

No início dessa fase, foi constado que a primeira versão do questionário não atingia os objetivos da pesquisa. O primeiro instrumento não apresentava as respostas conforme a escala de Likert, sendo as respostas frases longas com explicações, exemplo:

No prontuário do meu paciente: 
a) Coloco todos os tipos de informação, inclusive anotações sobre suas preferências e vida pessoal;

b) Coloco às vezes algumas informações adicionais além das informações clínicas;

c) Somente preencho as informações básicas além das informações clínicas;

d) Somente coloco nome, dados de contato além das informações clínicas.

Os profissionais se queixaram de dificuldade de entendimento e respostas que não condiziam com sua realidade, então o instrumento foi alterado a partir da reformulação das perguntas e respostas chegando em sua versão final, conforme consta no apêndice $A$.

\subsubsection{Fase 02: verificação da acurácia}

Após a finalização desta etapa, na qual foram realizadas todas as alterações necessárias nas perguntas, e quando o questionário foi considerado de fácil compreensão e capaz de mensurar o que foi proposto para a pesquisa, foi iniciada a segunda fase de validação (FASE 2), que foi realizada entre os meses de maio a setembro de 2013.

Nesta etapa, foi solicitado aos participantes que respondessem o questionário on-line duas vezes com um intervalo de tempo de 30 dias para se verificar o grau de acurácia nas respostas, por meio da correlação de Spermam. Para essa etapa também foram convidados profissionais do grupo de contato dos pesquisadores e todos foram convidados verbalmente para participarem da pesquisa. Para controle, os participantes recebiam um lembrete por e-mail para responderem novamente o questionário após 30 dias da data do registro de resposta inicial.

\subsubsection{Fase 03: validação}

Seguiu-se então para a fase final da validação (FASE 3), que consistiu em aplicar o questionário para cirurgiões-dentistas brasileiros. $O$ instrumento final 
encontra-se no Apêndice A. Devido ao propósito do trabalho, juntamente com a escala DMS-BR, também foi administrado o instrumento-escala de satisfação profissional DSS já validado no Brasil. Os participantes foram convidados por email com base em uma lista fornecida pelo CROSP, com envio do convite e o reenvio após cerca de 30 dias, além da divulgação do questionário por meio de redes sociais a partir do perfil pessoal da pesquisadora. A divulgação da pesquisa foi realizada no período de setembro a novembro de 2013. 


\subsection{INSTRUMENTOS DE COLETA}

Para melhor entendimento dos dois instrumentos utilizados na pesquisa, esta seção foi dividida em tópicos.

\subsubsection{Questionário 01: demográfico}

Para caracterização da amostra, foram elaboradas as seguintes perguntas:

- Em qual cidade e estado está localizado o seu local de trabalho?

- $\mathrm{O}$ ano de sua formatura

- Você se formou em faculdade pública ou privada?

- Responda onde você trabalha: aqui os respondentes poderiam escolher uma ou mais opções de resposta - consultório próprio, consultório de terceiros, setor público, franqueado, em rede de franquias ou outros.

- Qual a sua especialidade?

\subsubsection{Questionário 02: DMS-BR}

O instrumento em sua versão final possui 38 questões que abrangem 9 dimensões: ponto, marketing, paciente, equipe, qualidade, financeiro, produtividade, carreira e concorrência, como pode ser observado nos quadros de 4.1 a 4.9 .

O questionário foi estruturado no aplicativo Google Docs (Google, EUA), que consiste em uma plataforma para o desenvolvimento de questionários on-line em que se pode criar diversas formas de perguntas, como check-box, múltipla escolha, caixa de seleção. Os dados coletados foram armazenados sob a tecnologia de Cloud Computer, que consiste no armazenamento de dados em servidores compartilhados e conectados via internet e podem ser exportados para 
o software Microsoft Excel. As respostas possíveis foram: ótimo(a), bom(a), regular, fraco(a) e insatisfatório(a); essas respostas eram tabuladas respectivamente em: 5, 4, 3, 2, 1. Foi considerado que as médias dos resultados obtidos pelos respondentes quanto aos conhecimentos e aplicação de ferramentas de marketing e gestão seriam classificadas da seguinte forma: fraco (1 a <2); regular ( $>2,0$ a $<4,0)$; e satisfatório ( $>4$ a 5,0$)$.

\begin{tabular}{|l|l|}
\hline Dimensão & \multicolumn{1}{c|}{ Perguntas } \\
\hline Ponto & $\begin{array}{l}\text { 01. Como eu classifico a facilidade de acesso da clínica ou } \\
\text { consultório que trabalho; } \\
\text { 34. Considerando o seu público-alvo, você avalia a decoração } \\
\text { e o conforto de sua sala de espera como sendo; } \\
\text { 37. Classifico o estado de conservação e o visual da(s) } \\
\text { sala(s) de atendimento como sendo. }\end{array}$ \\
\hline
\end{tabular}

Quadro 4.1 - Parâmetros analisados na dimensão ponto

\begin{tabular}{|l|l|}
\hline Dimensão & \multicolumn{1}{c|}{ Perguntas } \\
\hline Paciente & $\begin{array}{l}\text { 02. Considerando as estratégias de relacionamento com seus } \\
\text { pacientes, como ligações para clientes antigos, envio de mala } \\
\text { direta, envio de e-mail, entre outras, considero a minha } \\
\text { situação como; } \\
\text { 06. Considerando a atenção que dedico ao meu paciente } \\
\text { antes, durante e após a consulta, classifico meu atendimento } \\
\text { como sendo: } \\
\text { 15. Quanto ao cumprimento do horário das consultas } \\
\text { agendadas, considero minha pontualidade como sendo; } \\
\text { 30. Como classifico a minha capacidade (ou de minha equipe) } \\
\text { de fidelizar os pacientes; } \\
\text { 31. Considerando as formas de avaliar a satisfação dos meus } \\
\text { clientes, classifico a minha situação como sendo. }\end{array}$ \\
\hline
\end{tabular}




\begin{tabular}{|l|l|}
\hline Dimensão & \multicolumn{1}{|c|}{ Perguntas } \\
\hline Financeiro & 03. Considerando pesquisa de preço antes de uma compra \\
importante e reserva financeira para a compra de materiais \\
e equipamentos, avalio meu comportamento como sendo; \\
23. Classifico o meu planejamento financeiro atual para \\
uma futura aposentadoria como sendo; \\
25. Considerando que o preço deve estar de acordo com \\
seus custos fixos e variáveis, como você considera a \\
formação dos preços cobrados em seu consultório; \\
26. Classifico o controle financeiro que faço em meu \\
consultório ou referente a ganhos/gastos profissionais como \\
sendo; \\
38. Como você classifica o seu conhecimento sobre os \\
gastos fixos e variáveis referentes ao seu consultório.
\end{tabular}

Quadro 4.3 - Parâmetros analisados na dimensão financeiro

\begin{tabular}{|l|l|}
\hline Dimensão & \multicolumn{1}{c|}{ Perguntas } \\
\hline Marketing & $\begin{array}{l}\text { 04. Quanto as estratégias para atrair novos clientes para o } \\
\text { consultório ou clínica que trabalho, como anúncios, } \\
\text { parcerias, divulgação em sites de pesquisa/busca, entre } \\
\text { outras, considero minha situação como sendo; } \\
\text { 10. Como avalio o meu conhecimento em áreas como } \\
\text { gestão, marketing e administração; } \\
\text { 11. Considerando a divulgação de meus serviços por meio } \\
\text { de material impresso ou digital, incluindo redes sociais, } \\
\text { site, folder, anúncios considero minha situação como } \\
\text { sendo; } \\
\text { 20. Considerando minha habilidade e dedicação em } \\
\text { relação a parte administrativa da profissão, classifico } \\
\text { minha atuação como sendo; } \\
\text { 35. Considero o meu conhecimento sobre o perfil de } \\
\text { pacientes que atendo, ou seja, meu público-alvo, como } \\
\text { sendo. }\end{array}$ \\
\hline
\end{tabular}

Quadro 4.4 - Parâmetros analisados na dimensão marketing 


\begin{tabular}{|l|l|}
\hline Dimensão & \multicolumn{1}{c|}{ Perguntas } \\
\hline Concorrência & 07. Classifico minha vantagem competitiva em relação aos \\
meus principais concorrentes como sendo; & 12. Classifico o meu conhecimento sobre os meus \\
& concorrentes como sendo; \\
& $\begin{array}{l}\text { 28. Classifico os meus conhecimentos sobre os pontos } \\
\text { fracos e pontos fortes do consultório ou clínica em que } \\
\text { trabalho como sendo. }\end{array}$ \\
\hline
\end{tabular}

Quadro 4.5 - Parâmetros analisados na dimensão concorrência

\begin{tabular}{|l|l|}
\hline Dimensão & \multicolumn{1}{|c|}{ Perguntas } \\
\hline Qualidade & $\begin{array}{l}\text { 05. Considerando a qualidade e organização das } \\
\text { informações, considero o prontuário dos meus pacientes } \\
\text { como sendo; } \\
\text { 16. Considerando o uso de gorro, máscara, luva, óculos e } \\
\text { avental, avalio minha proteção individual como sendo; } \\
\text { 18. Analisando a organização do meu consultório, incluindo } \\
\text { arquivos, fichas, materiais e equipamentos, classifico a } \\
\text { minha situação como sendo; } \\
\text { 24. Considerando aspectos como armazenamento, } \\
\text { disponibilidade, desperdício e planejamento de compra, } \\
\text { considero o controle do estoque de materiais do local onde } \\
\text { trabalho como sendo; } \\
\text { 24. Considerando características importantes para mim, } \\
\text { como classifico o desempenho dos meus principais } \\
\text { fornecedores (exemplo: dentais e laboratórios de prótese); } \\
\text { 29. Quanto às documentações legais, como por exemplo } \\
\text { ISS, alvará de funcionamento da vigilância sanitária } \\
\text { municipal, etc, classifico a situação do local onde trabalho } \\
\text { como sendo. }\end{array}$ \\
\hline
\end{tabular}

Quadro 4.6 - Parâmetros analisados na dimensão qualidade 


\begin{tabular}{|l|l|}
\hline Dimensão & \multicolumn{1}{|c|}{ Perguntas } \\
\hline Equipe & $\begin{array}{l}\text { 8. Classifico a qualidade da comunicação com a equipe com } \\
\text { quem trabalho como sendo; } \\
\text { 13. Considerando as características que julgo importante, } \\
\text { classifico o trabalho de meus funcionários e/ou equipe como } \\
\text { sendo; } \\
\text { 36. Considero a atenção dada aos comentários ou sugestões } \\
\text { sobre o funcionamento do consultório feitos por meus } \\
\text { funcionários, membros de minha equipe ou paciente como } \\
\text { sendo. }\end{array}$ \\
\hline
\end{tabular}

Quadro 4.7 - Parâmetros analisados na dimensão equipe

\begin{tabular}{|l|l|}
\hline Dimensão & \multicolumn{1}{c|}{ Perguntas } \\
\hline Carreira & $\begin{array}{l}\text { 09. Em relação à minha vida profissional, considero o } \\
\text { planejamento de estratégias para atingir meus objetivos futuros } \\
\text { como sendo; } \\
\text { 17. Analisando os quatro últimos anos, considero a quantidade e } \\
\text { a qualidade dos cursos que frequentei como sendo; } \\
\text { 19. Analisando a ergonomia do local de atendimento, considero a } \\
\text { disposição dos móveis, equipamentos e materiais como sendo; } \\
\text { 27. Considero a profissão de cirurgião-dentista como sendo. }\end{array}$ \\
\hline
\end{tabular}

Quadro 4.8 - Parâmetros analisados na dimensão carreira

\begin{tabular}{|l|l|}
\hline Dimensão & \multicolumn{1}{c|}{ Perguntas } \\
\hline Produtividade & $\begin{array}{l}\text { 14. Em relação à venda de meus serviços, classifico o meu } \\
\text { conhecimento sobre técnicas de negociação e/ou poder de } \\
\text { convencimento sobre meus clientes como sendo; } \\
\text { 22. Considerando minha produtividade e eficiência de trabalho, } \\
\text { classifico minha situação como; } \\
\text { 32. Classifico o controle de fluxo de pacientes (retornos, novos, } \\
\text { faltas, atrasos) do local que trabalho como sendo; } \\
\text { 33. Considerando a quantidade de pacientes que recebo } \\
\text { mensalmente por meio do boca a boca ou indicação de colegas, } \\
\text { classifico minha situação como sendo. }\end{array}$ \\
\hline
\end{tabular}

Quadro 4.9 - Parâmetros analisados na dimensão produtividade 


\subsubsection{Questionário 03: Escala sobre satisfação profissional}

Para avaliar a satisfação profissional dos cirurgiões-dentistas foi utilizado o instrumento Dentist Satisfaction Survey - DSS (Jeong et al., 2006) em sua versão validada para o português do Brasil (Michel-Crosato, 2008).

O instrumento consiste em 7 blocos que compreendem ao todo 29 perguntas. Os parâmetros analisados em cada bloco e as respectivas questões podem ser verificados nos Quadros 4.10 a 4.16. O instrumento completo encontra-se no Apêndice B. A média aritmética dos itens de cada bloco foi calculada para acessar o escore de satisfação fragmentado. A soma das médias dos blocos resulta no escore de satisfação geral sobre a profissão, sendo: insatisfeito (1 a 2,5$)$; neutro $(>2,5$ a $<3,5)$; e satisfeito $(>3,5$ a 5,0$)$.

\begin{tabular}{|l|l|}
\hline Bloco & \multicolumn{1}{|c|}{ Perguntas } \\
\hline Satisfação & 05. A odontologia preenche minhas atuais aspirações com \\
geral com o & a carreira; \\
trabalho / & 06. Gostaria de deixar o meu emprego/trabalho para fazer \\
emprego & outra coisa; \\
& 09. Eu pareço mais satisfeito/a com meu trabalho/emprego \\
& 12- do que realmente estou; \\
& 12. Sabendo o que eu sei hoje, eu teria tomado a mesma \\
& decisão de fazer odontologia novamente; \\
& 14. A odontologia é a área onde eu posso oferecer minha \\
& melhor contribuição profissional; \\
& 17. Em geral, estou extremamente satisfeito com minha \\
& carreira; \\
& 20. Sinto-me limitado em minha posição / meu cargo atual. \\
\hline
\end{tabular}

Quadro 4.10 - Parâmetros analisados no bloco satisfação geral 


\begin{tabular}{|l|l|}
\hline Bloco & \multicolumn{1}{c|}{ Perguntas } \\
\hline $\begin{array}{l}\text { Percepção } \\
\text { de renda }\end{array}$ & $\begin{array}{l}\text { 02. Minha renda permite que eu sustente minha família } \\
\text { muito bem; } \\
\text { 10. Comparado a outros cirurgiões-dentistas, meus ganhos } \\
\text { totais são muito menores do que eu gostaria; } \\
\text { 21. A renda que recebo de minha prática é, na maior parte } \\
\text { das vezes, satisfatória para minhas necessidades; } \\
\text { 23. Minha renda não é, nem de perto, tão alta quanto à de } \\
\text { outros cirurgiões-dentistas; } \\
\text { 25. Minha renda pode ser comparada favoravelmente à de } \\
\text { outros cirurgiões-dentistas. }\end{array}$ \\
\hline
\end{tabular}

Quadro 4.11 - Parâmetros analisados no bloco percepção de renda

\begin{tabular}{|l|l|}
\hline Bloco & \multicolumn{1}{c|}{ Perguntas } \\
\hline Tempo & $\begin{array}{l}\text { 07. Tenho suficiente tempo disponível para minha vida } \\
\text { pessoal }\end{array}$ \\
& $\begin{array}{l}\text { 15. Tenho tempo suficiente para atividades de lazer; } \\
\text { 29. Tempo pouquíssimo tempo disponível para atividades } \\
\text { de lazer. }\end{array}$ \\
\hline
\end{tabular}

Quadro 4.12 - Parâmetros analisados no bloco tempo pessoal

\begin{tabular}{|l|l|}
\hline Bloco & \multicolumn{1}{c|}{ Perguntas } \\
\hline Tempo & $\begin{array}{l}\text { 01. Eu tenho pouquíssimo tempo para me manter } \\
\text { Profissional }\end{array}$ \\
& $\begin{array}{l}\text { 04. Tenho tempo suficiente para melhorar minhas } \\
\text { habilidades clínicas; } \\
\text { 22. Tenho tempo suficiente para contatos profissionais com } \\
\text { colegas; } \\
\text { 26. Tenho oportunidades muito limitadas de discutir casos } \\
\text { difíceis com colegas. }\end{array}$ \\
\hline
\end{tabular}

Quadro 4.13 - Parâmetros analisados no bloco tempo profissional

\begin{tabular}{|l|l|}
\hline Bloco & \multicolumn{1}{c|}{ Perguntas } \\
\hline Equipe & $\begin{array}{l}\text { 08. A qualidade de meu pessoal auxiliar deixa a desejar; } \\
\text { 18. O rendimento de meus auxiliares é excelente; } \\
\text { 19. A equipe da clínica trabalha bem em conjunto. }\end{array}$ \\
\hline
\end{tabular}

Quadro 4.14 - Parâmetros analisados no bloco equipe 


\begin{tabular}{|l|l|}
\hline Bloco & \multicolumn{1}{c|}{ Perguntas } \\
\hline $\begin{array}{l}\text { Relacionamento } \\
\text { com pacientes }\end{array}$ & $\begin{array}{l}\text { 11. Relacionar-me com pacientes, para mim, é muito } \\
\text { frustrante; } \\
\text { 16. Eu não gosto de interagir com meus pacientes; } \\
\text { 24. A qualidade da assistência interpessoal que eu } \\
\text { ofereço é muito alta; } \\
\text { 27. Eu gosto de ajudar meus pacientes. }\end{array}$ \\
\hline
\end{tabular}

Quadro 4.15 - Parâmetros analisados no bloco relacionamento com pacientes

\begin{tabular}{|l|l|}
\hline Bloco & \multicolumn{1}{|c|}{ Perguntas } \\
\hline Fornecimento de & 03. Eu estou tecnicamente preparado para lidar com os \\
assistência / & problemas odontológicos de meus pacientes; \\
atendimento & 13. Eu perco oportunidades de fornecer \\
& assistência/atendimento de qualidade; \\
& 28. Eu tenho muita satisfação com a qualidade técnica \\
& de meu trabalho. \\
\hline
\end{tabular}

Quadro 4.16 - Parâmetros analisados no bloco fornecimento de assistência/atendimento

As respostas foram tabuladas conforme a afirmação. Caso a afirmação fosse positiva, sua tabulação era decrescente e nos casos de afirmações negativas, correspondente às afirmações números $1,6,8,9,10,11,13,16,20$, 23, 26 e 29, a tabulação foi invertida, conforme o Quadro 4.17.

\begin{tabular}{|c|c|c|}
\hline Resposta & Tabulação & Tabulação invertida \\
\hline Discordo fortemente & 1 & 4 \\
\hline Discordo & 2 & 3 \\
\hline Neutro & 3 & 2 \\
\hline Concordo & 4 & 1 \\
\hline Concordo fortemente & 5 & 5 \\
\hline
\end{tabular}

Quadro 4.17 - Tabulações das respostas da escala de satisfação 


\subsection{DIGITAÇÃO E ANÁLISE DOS DADOS}

Os dados foram coletados em uma folha de respostas fornecida pelo aplicativo Google Docs e ficaram armazenados sob a tecnologia de cloud computer.

Para a realização da análise, os dados foram exportados desta plataforma e inseridos no software Microsoft Excel, onde foram preparados para a análise estatística.

A análise das respostas do estudo foi realizada no programa STATA 13.0, com o qual foi possível obter a distribuição de frequências e medidas de tendência central e de dispersão, e também foram verificados os valores mínimos e máximos.

Para a análise dos resultados da fase 02 , as respostas dos participantes nos dois momentos distintos foram comparadas pode meio do teste de correlação de Spermam.

Para verificar a validade do DMS-BR, foram utilizados o teste Alpha Cronbach e o teste de correlação de Spermam. O nível de significância considerado foi de $5 \%(p<0,05)$ para todos os testes realizados neste estudo.

A comparação entre os resultados da escala DMS-BR e DSS foi obtida também por meio do teste de correlação de Spermam.

\subsection{CONSIDERAÇÕES ÉTICAS}

O projeto de pesquisa obteve a aprovação no Comitê de Ética em Pesquisa (CEP) da Faculdade de Odontologia da Universidade de São Paulo (ANEXO A).

Nas etapas presenciais, o Termo de Consentimento Livre e Esclarecido foi preenchido, em duas vias, conforme preconiza a Resolução 196 do Conselho Nacional de Ética em Pesquisa (CONEP).

Para as etapas on-line, os participantes da pesquisa deveriam ler o Termo de Consentimento Livre e Esclarecido, que aparecia na página inicial do site, e aceitar participar da pesquisa, para, a partir daí, acessar ao questionário. Nesta etapa, também foram disponibilizados os contatos dos pesquisadores para que o 
participante pudesse entrar em contato em caso de dúvidas, não prejudicando a integridade do participante em nenhum momento da pesquisa. 


\section{RESULTADOS}

\subsection{RESULTADOS DA VALIDAÇÃO DMS-BR}

Os resultados da validação do instrumento DMS-BR serão apresentados nos tópicos a seguir.

\subsubsection{Fase 01: desenvolvimento do questionário}

Desta etapa, participaram 10 cirurgiões-dentistas da região de São Paulo, Osasco e Barueri, que foram selecionados por conveniência. As entrevistas da auditoria, de duração média entre uma hora e meia e duas horas, mostraram que o questionário, em sua versão final após reformulação, estava condizendo com seu propósito. Os entrevistados também relataram bom entendimento das questões.

\subsubsection{Fase 02: verificação da acurácia do instrumento}

Do total de 23 cirurgiões-dentistas que responderam o questionário nesta fase, 09 o fizeram após 30 dias. A amostra foi de conveniência e composta por cirurgiões-dentistas de São Paulo. Os resultados da correlação de Spermam mostram que não houve diferença estatisticamente significante $(p>0,05)$ entre a primeira e a segunda resposta, garantindo a acurácia do instrumento, conforme dados da Tabela 5.1 . 
Tabela 5.1 - Valores de média, diferença entre as médias e p para as respostas da fase de validação do questionário do instrumento DMS-BR.

\begin{tabular}{llcll}
\hline \multicolumn{1}{c}{ Dimensões } & $\begin{array}{c}\text { Média } \\
\text { Primeira } \\
\text { Resposta }\end{array}$ & $\begin{array}{c}\text { Média } \\
\text { Segunda resposta } \\
\text { intervalo de } 30 \text { dias }\end{array}$ & $\begin{array}{c}\text { Diferença } \\
\text { entre as } \\
\text { médias }\end{array}$ & Valor de p \\
\hline Qualidade & 4,11 & 4,15 & 0,37 & 0,7719 \\
Equipe & 4,22 & 4,04 & 0,18 & 0,3768 \\
Ponto & 4,00 & 3,85 & 1,48 & 0,4354 \\
Carreira & 3,97 & 3,94 & 0,28 & 0,9176 \\
Paciente & 3,80 & 3,60 & 0,20 & 0,4132 \\
Concorrência & 3,63 & 3,55 & 0,74 & 0,7388 \\
Produtividade & 3,72 & 3,70 & 0,28 & 0,9034 \\
Marketing & 3,11 & 3,07 & 0,44 & 0,7388 \\
Financeiro & 3,04 & 3,29 & 0,11 & 0,7958 \\
\hline
\end{tabular}

\subsubsection{Fase 03: validação do questionário DMS-BR}

Para melhor entendimento do leitor, os resultados da fase 03 da validação também serão desmembrados em tópicos.

5.2.3.1 Fase 03: caracterização da amostra

Participaram da FASE 03 do estudo 247 cirurgiões-dentistas, predominantemente da região Sudeste $(81,78 \%)$, sendo a em sua grande maioria do Estado de São Paulo, entretanto com representantes de todas as regiões do país (tabela 5.2).

Mais da metade dos cirurgiões-dentistas da amostra cursaram a graduação em universidade particular, 80,16\% possuem consultório próprio e 40,49\% declararam ser clínico geral e não possuíam nenhuma especialização. A especialização mais frequente foi Ortodontia, seguido de Implantodontia. Os 
dados completos da caracterização da amostra podem ser visualizados na Tabela 5.3 .

Tabela 5.2 - Caracterização da amostra por especialidades odontológicas

\begin{tabular}{lcc}
\hline Especialidade & Número absoluto & Porcentagem \\
\hline Clínica Geral & 100 & $40.49 \%$ \\
Ortodontia & 49 & $19,84 \%$ \\
Implantodontia & 39 & $15,79 \%$ \\
Prótese & 30 & $12,15 \%$ \\
Dentística & 31 & $12,55 \%$ \\
Endodontia & 25 & $10,12 \%$ \\
Periodontia & 16 & $6,48 \%$ \\
Odontopediatria & 13 & $5,26 \%$ \\
Ortopedia funcional dos maxilares & 13 & $5,26 \%$ \\
Cirurgia bucomaxilofacial & 11 & $4,45 \%$ \\
Saúde coletiva & 11 & $4,45 \%$ \\
Desordens temporomandibular & 8 & $3,24 \%$ \\
Radiologia & 8 & $3,24 \%$ \\
Odontologia do trabalho & 7 & $2,23 \%$ \\
Patologia & 4 & $1,62 \%$ \\
Estomatologia & 4 & $1,62 \%$ \\
Pacientes Especiais & 3 & $1,21 \%$ \\
Odontologia Legal & 3 & $1,21 \%$ \\
Odontogeriatria & 3 & $1,21 \%$ \\
Prótese bucomaxilofacial & 2 & $0,81 \%$ \\
\hline
\end{tabular}


Tabela 5.3 - Caracterização da amostra por dados de região onde trabalha, anos de formação e área de atuação

\begin{tabular}{l|l|c|c}
\hline \multicolumn{2}{l}{} & \multicolumn{2}{c}{$\begin{array}{c}\text { Número } \\
\text { absoluto }\end{array}$} \\
\hline \multirow{2}{*}{$\begin{array}{l}\text { Região onde } \\
\text { trabalha }\end{array}$} & Sudeste & 202 & $81,78 \%$ \\
& Sul & 22 & $8,91 \%$ \\
& Nordeste & 12 & $4,86 \%$ \\
Anos de & Centro-oeste & 10 & $4,05 \%$ \\
formado & Norte & 1 & $0,40 \%$ \\
\hline \multirow{3}{*}{\begin{tabular}{l} 
Onde atua \\
\cline { 2 - 3 }
\end{tabular}} & Menos de 5 anos & 28 & $11,34 \%$ \\
& Entre 5 e 10 anos & 31 & $12,55 \%$ \\
& Entre 10 e 15 anos & 46 & $18,62 \%$ \\
& Mais de 15 anos & 142 & $57,49 \%$ \\
\hline & Consultório próprio & 198 & $80,16 \%$ \\
& Consultório de terceiros & 75 & $30,36 \%$ \\
& Setor público & 42 & $17,00 \%$ \\
& Outros & 39 & $15,79 \%$ \\
& Em redes de franquias & 13 & $5.26 \%$ \\
& Franqueados & 3 & $1,21 \%$ \\
\hline
\end{tabular}

\subsubsection{Fase 03: distribuição}

$\mathrm{Na}$ dimensão referente ao ponto do estabelecimento comercial, a grande maioria dos cirurgiões-dentistas classificam o acesso, a decoração e o conforto da sala de espera, o estado de conservação e o visual da sala de atendimento como sendo bom ou ótimo (Tabela 5.4). 
Tabela 5.4 - Frequência de resposta para o instrumento DMS-BR (dimensão: ponto)

\begin{tabular}{l|c|c|c}
\hline \multicolumn{2}{c|}{ Ponto } & $\begin{array}{c}\text { Número } \\
\text { absoluto }\end{array}$ & Porcentagem \\
\hline 01. Como eu classifico a & & 121 & $48,99 \%$ \\
facilidade de acesso da clínica & Ótimo & 105 & $42,51 \%$ \\
ou consultório que trabalho; & Bom & 18 & $7,29 \%$ \\
& Regular & 2 & $0,81 \%$ \\
& Fraco & 1 & $0,40 \%$ \\
\hline 34. Considerando o seu & Insatisfatório & 247 & $100 \%$ \\
\cline { 2 - 4 } público-alvo, você avalia a & Total & 68 & $27,53 \%$ \\
decoração e o conforto de sua & Ótimo & 129 & $52,23 \%$ \\
sala de espera como sendo; & Bom & 38 & $15,38 \%$ \\
& Regular & 10 & $4,05 \%$ \\
& Fraco & 2 & $0,81 \%$ \\
\hline 37. Classifico o estado de & Insatisfatório & 247 & $100 \%$ \\
\cline { 2 - 4 } conservação e o visual da(s) & Total & 100 & $40,49 \%$ \\
sala(s) de atendimento como & Ótimo & 123 & $49,80 \%$ \\
sendo. & Bom & 19 & $7,69 \%$ \\
& Regular & 5 & $2,02 \%$ \\
& Fraco & 0 & $0,00 \%$ \\
\hline
\end{tabular}

Pouquíssimos profissionais consideram a atenção dedicada aos pacientes como insuficiente, ou seja, fraca ou insatisfatória. Entretanto, apenas cerca de $5 \%$ consideram como ótima as estratégias de relacionamento com o cliente, como ligações telefônicas, e-mail, etc. Ainda grande parte dos cirurgiões-dentistas da amostra se consideram bons ou ótimos na capacidade de fidelizar os clientes, bem como no cumprimento do horário das consultas agendadas (Tabela 5.5). 
Tabela 5.5 - Frequência de resposta para o instrumento DMS-BR (dimensão: paciente)

\begin{tabular}{|c|c|c|c|}
\hline \multicolumn{2}{|l|}{ Paciente } & \multirow{2}{*}{$\begin{array}{c}\text { Número } \\
\text { absoluto }\end{array}$} & \multirow{2}{*}{$\frac{\text { Porcentagem }}{5,26 \%}$} \\
\hline \multirow{6}{*}{$\begin{array}{l}\text { 02. Considerando as estratégias de } \\
\text { relacionamento com seus } \\
\text { pacientes, como ligações para } \\
\text { clientes antigos, envio de mala } \\
\text { direta, envio de e-mail, entre outras, } \\
\text { considero a minha situação como }\end{array}$} & Ótimo & & \\
\hline & Bom & 64 & $25,91 \%$ \\
\hline & Regular & 74 & $29,96 \%$ \\
\hline & Fraco & 69 & $27,94 \%$ \\
\hline & Insatisfatório & 27 & $10,93 \%$ \\
\hline & Total & 247 & $100 \%$ \\
\hline \multirow{6}{*}{$\begin{array}{l}\text { 06. Considerando a atenção que } \\
\text { dedico ao meu paciente antes, } \\
\text { durante e após a consulta, } \\
\text { classifico meu atendimento como } \\
\text { sendo; }\end{array}$} & Ótimo & 125 & $50,61 \%$ \\
\hline & Bom & 105 & $42,51 \%$ \\
\hline & Regular & 16 & $6,48 \%$ \\
\hline & Fraco & 1 & $0.40 \%$ \\
\hline & Insatisfatório & 0 & $0,00 \%$ \\
\hline & Total & 247 & $100 \%$ \\
\hline \multirow{6}{*}{$\begin{array}{l}\text { 15. Quanto ao cumprimento do } \\
\text { horário das consultas agendadas, } \\
\text { considero minha pontualidade como } \\
\text { sendo; }\end{array}$} & Ótimo & 145 & $58,70 \%$ \\
\hline & Bom & 80 & $32,39 \%$ \\
\hline & Regular & 19 & $7,69 \%$ \\
\hline & Fraco & 2 & $0,81 \%$ \\
\hline & Insatisfatório & 1 & $0,40 \%$ \\
\hline & Total & 247 & $100 \%$ \\
\hline \multirow{6}{*}{$\begin{array}{l}\text { 30. Como classifico a minha } \\
\text { capacidade (ou de minha equipe) } \\
\text { de fidelizar os pacientes; }\end{array}$} & Ótimo & 52 & $21,05 \%$ \\
\hline & Bom & 128 & $51,82 \%$ \\
\hline & Regular & 58 & $23,, 48 \%$ \\
\hline & Fraco & 9 & $3,64 \%$ \\
\hline & Insatisfatório & 0 & $0.00 \%$ \\
\hline & Total & 247 & $100 \%$ \\
\hline \multirow{6}{*}{$\begin{array}{l}\text { 31. Considerando as formas de } \\
\text { avaliar a satisfação dos meus } \\
\text { clientes, classifico a minha situação } \\
\text { como sendo. }\end{array}$} & Ótimo & 34 & $13,77 \%$ \\
\hline & Bom & 113 & $45,75 \%$ \\
\hline & Regular & 67 & $27,13 \%$ \\
\hline & Fraco & 27 & $10,93 \%$ \\
\hline & Insatisfatório & 6 & $2,43 \%$ \\
\hline & Total & 247 & $100 \%$ \\
\hline
\end{tabular}


Considerando a dimensão sobre finanças, mais da metade dos cirurgiõesdentistas que responderam o questionário relataram que possuem, de regular a insatisfatório, um planejamento para uma futura aposentadoria. Além disso, a grande maioria considera o controle das movimentações financeiras profissionais como boas ou regulares e mais da metade dos profissionais disseram que seus conhecimentos sobre gastos fixos e variáveis do consultório são ótimos ou bons (Tabela 5.6).

Tabela 5.6 - Frequência de resposta para o instrumento DMS-BR (dimensão: financeiro)

\begin{tabular}{|c|c|c|c|}
\hline \multicolumn{2}{|l|}{ Financeiro } & \multirow{2}{*}{$\begin{array}{c}\begin{array}{c}\text { Número } \\
\text { absoluto }\end{array} \\
30 \\
113 \\
72 \\
25 \\
07\end{array}$} & \multirow{2}{*}{$\begin{array}{c}\text { Porcentagem } \\
12,15 \% \\
45,75 \% \\
29,15 \% \\
10,12 \% \\
2,81 \%\end{array}$} \\
\hline $\begin{array}{l}\text { 03. Considerando pesquisa de } \\
\text { preço antes de uma compra } \\
\text { importante e reserva financeira } \\
\text { para a compra de materiais e } \\
\text { equipamentos, avalio meu } \\
\text { comportamento como sendo; }\end{array}$ & $\begin{array}{l}\text { Ótimo } \\
\text { Bom } \\
\text { Regular } \\
\text { Fraco } \\
\text { Insatisfatório }\end{array}$ & & \\
\hline & Total & 247 & $100 \%$ \\
\hline \multirow[t]{2}{*}{$\begin{array}{l}\text { 23. Classifico o meu } \\
\text { planejamento financeiro atual } \\
\text { para uma futura aposentadoria } \\
\text { como sendo; }\end{array}$} & $\begin{array}{c}\text { Ótimo } \\
\text { Bom } \\
\text { Regular } \\
\text { Fraco } \\
\text { Insatisfatório }\end{array}$ & $\begin{array}{l}23 \\
73 \\
71 \\
52 \\
28\end{array}$ & $\begin{array}{c}9,31 \% \\
29,55 \% \\
28,74 \% \\
21,05 \% \\
11,34 \%\end{array}$ \\
\hline & Total & 247 & $100 \%$ \\
\hline \multirow[t]{2}{*}{$\begin{array}{l}\text { 25. Considerando que o preço } \\
\text { deve estar de acordo com seus } \\
\text { custos fixos e variáveis, como } \\
\text { você considera a formação dos } \\
\text { preços cobrados em seu } \\
\text { consultório; }\end{array}$} & $\begin{array}{l}\text { Ótimo } \\
\text { Bom } \\
\text { Regular } \\
\text { Fraco } \\
\text { Insatisfatório }\end{array}$ & $\begin{array}{c}24 \\
136 \\
64 \\
19 \\
4\end{array}$ & $\begin{array}{c}9,72 \% \\
55,06 \% \\
25,91 \% \\
7,69 \% \\
1,62 \%\end{array}$ \\
\hline & Total & 247 & $100 \%$ \\
\hline \multirow[t]{2}{*}{$\begin{array}{l}\text { 26. Classifico o controle } \\
\text { financeiro que faço em meu } \\
\text { consultório ou referente a } \\
\text { ganhos/gastos profissionais } \\
\text { como sendo; }\end{array}$} & $\begin{array}{l}\text { Ótimo } \\
\text { Bom } \\
\text { Regular } \\
\text { Fraco } \\
\text { Insatisfatório }\end{array}$ & $\begin{array}{c}30 \\
110 \\
70 \\
27 \\
10\end{array}$ & $\begin{array}{c}12,15 \% \\
44,53 \% \\
28,34 \% \\
10,93 \% \\
4,05 \%\end{array}$ \\
\hline & Total & 247 & $100 \%$ \\
\hline \multirow[t]{2}{*}{$\begin{array}{l}\text { 38. Como você classifica o seu } \\
\text { conhecimento sobre os gastos } \\
\text { fixos e variáveis referentes ao } \\
\text { seu consultório. }\end{array}$} & $\begin{array}{c}\text { Ótimo } \\
\text { Bom } \\
\text { Regular } \\
\text { Fraco } \\
\text { Insatisfatório }\end{array}$ & $\begin{array}{c}52 \\
98 \\
69 \\
20 \\
8\end{array}$ & $\begin{array}{c}21,05 \% \\
39,68 \% \\
27,94 \% \\
8.10 \% \\
3,24\end{array}$ \\
\hline & Total & 247 & $100 \%$ \\
\hline
\end{tabular}


A análise das respostas da dimensão de perguntas referentes ao instrumento DMS-BR, revela que apenas uma minoria considera as estratégias de divulgação dos serviços odontológicos como ótimas. Além disso, mais da metade da amostra classifica como fraco seu conhecimento sobre marketing e gestão, entretanto consideram como boa/regular sua dedicação e habilidade às obrigações administrativas da profissão. Os resultados mostram, ainda, que os cirurgiões-dentistas possuem um bom conhecimento sobre o público-alvo de seus estabelecimentos (Tabela 5.7). 
Tabela 5.7 - Frequência de resposta para o instrumento DMS-BR (dimensão: marketing)

\begin{tabular}{|c|c|c|c|}
\hline \multicolumn{2}{|l|}{ Marketing } & \multirow{2}{*}{$\begin{array}{c}\begin{array}{c}\text { Número } \\
\text { absoluto }\end{array} \\
7 \\
58 \\
78 \\
68 \\
36\end{array}$} & \multirow{2}{*}{$\begin{array}{c}\text { Porcentagem } \\
2,83 \% \\
23,48 \% \\
31,58 \% \\
27,53 \% \\
14,57 \%\end{array}$} \\
\hline $\begin{array}{l}\text { 04. Quanto as estratégias para } \\
\text { atrair novos clientes para o } \\
\text { consultório ou clínica que } \\
\text { trabalho, como anúncios, } \\
\text { parcerias, divulgação em sites de } \\
\text { pesquisa/busca, entre outras, }\end{array}$ & $\begin{array}{l}\text { Ótimo } \\
\text { Bom } \\
\text { Regular } \\
\text { Fraco } \\
\text { Insatisfatório }\end{array}$ & & \\
\hline sendo; & Total & 247 & $100 \%$ \\
\hline \multirow[t]{2}{*}{$\begin{array}{l}\text { 10. Como avalio o meu } \\
\text { conhecimento em áreas como } \\
\text { gestão, marketing e } \\
\text { administração; }\end{array}$} & $\begin{array}{c}\text { Ótimo } \\
\text { Bom } \\
\text { Regular } \\
\text { Fraco } \\
\text { Insatisfatório }\end{array}$ & $\begin{array}{c}16 \\
81 \\
0 \\
132 \\
18 \\
\end{array}$ & $\begin{array}{c}6,48 \% \\
32,79 \% \\
0,00 \% \\
53,44 \% \\
7,29 \% \\
\end{array}$ \\
\hline & Total & 247 & $100 \%$ \\
\hline \multirow[t]{2}{*}{$\begin{array}{l}\text { 11. Considerando a divulgação } \\
\text { de meus serviços por meio de } \\
\text { material impresso ou digital, } \\
\text { incluindo redes sociais, site, } \\
\text { folder, anúncios considero minha } \\
\text { situação como sendo; }\end{array}$} & $\begin{array}{l}\text { Ótimo } \\
\text { Bom } \\
\text { Regular } \\
\text { Fraco } \\
\text { Insatisfatório }\end{array}$ & $\begin{array}{c}9 \\
44 \\
84 \\
68 \\
42\end{array}$ & $\begin{array}{l}3,64 \% \\
17,81 \% \\
34,01 \% \\
27,53 \% \\
17,00 \%\end{array}$ \\
\hline & Total & 247 & $100 \%$ \\
\hline \multirow[t]{2}{*}{$\begin{array}{l}\text { 20. Considerando minha } \\
\text { habilidade e dedicação em } \\
\text { relação a parte administrativa da } \\
\text { profissão, classifico minha } \\
\text { atuação como sendo; }\end{array}$} & $\begin{array}{l}\text { Ótimo } \\
\text { Bom } \\
\text { Regular } \\
\text { Fraco } \\
\text { Insatisfatório }\end{array}$ & $\begin{array}{c}22 \\
105 \\
95 \\
22 \\
03\end{array}$ & $\begin{array}{c}8,91 \% \\
42,51 \% \\
38,46 \% \\
8,91 \% \\
1,21 \%\end{array}$ \\
\hline & Total & 247 & $100, \%$ \\
\hline \multirow[t]{2}{*}{$\begin{array}{l}\text { 35. Considero o meu } \\
\text { conhecimento sobre o perfil de } \\
\text { pacientes que atendo, ou seja, } \\
\text { meu público-alvo, como sendo. }\end{array}$} & $\begin{array}{c}\text { Ótimo } \\
\text { Bom } \\
\text { Regular } \\
\text { Fraco } \\
\text { Insatisfatório }\end{array}$ & $\begin{array}{c}34 \\
164 \\
41 \\
07 \\
01\end{array}$ & $\begin{array}{c}13,77 \% \\
66,40 \% \\
16,60 \% \\
2,83 \% \\
0,40 \%\end{array}$ \\
\hline & Total & 247 & $100 \%$ \\
\hline
\end{tabular}


Da análise da dimensão concorrência, foi possível observar que mais da metade da amostra acha que seu conhecimento sobre a concorrência é de regular a insatisfatória, entretanto também classificam que possuem uma situação ótima ou boa em relação a sua vantagem competitiva no mercado (Tabela 5.8).

Tabela 5.8 - Frequência de resposta para o instrumento DMS-BR (dimensão: concorrência)

\begin{tabular}{|c|c|c|c|}
\hline \multicolumn{2}{|l|}{ Concorrência } & \multirow{2}{*}{$\begin{array}{c}\text { Número } \\
\text { absoluto }\end{array}$} & \multirow{2}{*}{$\frac{\text { Porcentagem }}{15,79}$} \\
\hline \multirow{6}{*}{$\begin{array}{l}\text { 07. Classifico minha vantagem } \\
\text { competitiva em relação aos meus } \\
\text { principais concorrentes como } \\
\text { sendo; }\end{array}$} & Ótimo & & \\
\hline & Bom & 141 & 57,09 \\
\hline & Regular & 52 & 21,05 \\
\hline & Fraco & 14 & 5,67 \\
\hline & Insatisfatório & 1 & 0,40 \\
\hline & Total & 247 & $100 \%$ \\
\hline \multirow{6}{*}{$\begin{array}{l}\text { 12. Classifico o meu } \\
\text { conhecimento sobre os meus } \\
\text { concorrentes como sendo; }\end{array}$} & Ótimo & 31 & 12,55 \\
\hline & Bom & 90 & 36,44 \\
\hline & Regular & 71 & 28,74 \\
\hline & Fraco & 44 & 17,81 \\
\hline & Insatisfatório & 11 & 4,45 \\
\hline & Total & 247 & $100 \%$ \\
\hline \multirow{6}{*}{$\begin{array}{l}\text { 28. Classifico os meus } \\
\text { conhecimentos sobre os pontos } \\
\text { fracos e pontos fortes do } \\
\text { consultório ou clínica em que } \\
\text { trabalho como sendo. }\end{array}$} & Ótimo & 41 & 16,60 \\
\hline & Bom & 146 & 59,11 \\
\hline & Regular & 51 & 20,65 \\
\hline & Fraco & 7 & 2,83 \\
\hline & Insatisfatório & 2 & 0,81 \\
\hline & Total & 247 & $100 \%$ \\
\hline
\end{tabular}

Analisando a dimensão qualidade, demonstra-se que a grande maioria considera o consultório organizado, assim como as informações dos prontuários dos pacientes. Nenhum dentista considerou como insatisfatória a questão do uso de EPIs, entretanto, cerca de $4 \%$ da amostra considerou o seu comportamento nesse quesito como sendo regular ou fraco. Em relação a documentação legal do consultório, cerca de $20 \%$ declararam sua situação como sendo regular, fraca ou ainda insatisfatória (Tabela 5.9). 
Tabela 5.9 - Frequência de resposta para o instrumento DMS-BR (dimensão: qualidade)

\begin{tabular}{|c|c|c|c|}
\hline \multicolumn{2}{|l|}{ Qualidade } & \multirow{6}{*}{$\begin{array}{c}\begin{array}{c}\text { Número } \\
\text { absoluto }\end{array} \\
56 \\
123 \\
45 \\
19 \\
4\end{array}$} & \multirow{6}{*}{$\begin{array}{c}\text { Porcentagen } \\
22,67 \% \\
49,80 \% \\
18,22 \% \\
7,69 \% \\
1,62 \%\end{array}$} \\
\hline \multirow{6}{*}{$\begin{array}{l}\text { 05. Considerando a qualidade e } \\
\text { organização das informações, } \\
\text { considero o prontuário dos meus } \\
\text { pacientes como sendo; }\end{array}$} & Ótimo & & \\
\hline & Bom & & \\
\hline & Regular & & \\
\hline & Fraco & & \\
\hline & Insatisfatório & & \\
\hline & Total & 247 & $100 \%$ \\
\hline \multirow{6}{*}{$\begin{array}{l}\text { 16. Considerando o uso de gorro, } \\
\text { máscara, luva, óculos e avental, } \\
\text { avalio minha proteção individual } \\
\text { como sendo; }\end{array}$} & Ótimo & 170 & $68,83 \%$ \\
\hline & Bom & 67 & $27,13 \%$ \\
\hline & Regular & 7 & $2,83 \%$ \\
\hline & Fraco & 3 & $1,21 \%$ \\
\hline & Insatisfatório & 0 & $0,00 \%$ \\
\hline & Total & 247 & $100 \%$ \\
\hline \multirow{6}{*}{$\begin{array}{l}\text { 18. Analisando a organização do } \\
\text { meu consultório, incluindo } \\
\text { arquivos, fichas, materiais e } \\
\text { equipamentos, classifico a minha } \\
\text { situação como sendo; }\end{array}$} & Ótimo & 77 & $31,17 \%$ \\
\hline & Bom & 125 & $50,61 \%$ \\
\hline & Regular & 36 & $14,57 \%$ \\
\hline & Fraco & 8 & $3,24 \%$ \\
\hline & Insatisfatório & 1 & $0,40 \%$ \\
\hline & Total & 247 & $100 \%$ \\
\hline \multirow{6}{*}{$\begin{array}{l}\text { 21. Considerando aspectos como } \\
\text { armazenamento, disponibilidade, } \\
\text { desperdício e planejamento de } \\
\text { compra, considero o controle do } \\
\text { estoque de materiais do local } \\
\text { onde trabalho como sendo; }\end{array}$} & Ótimo & 54 & $21,86 \%$ \\
\hline & Bom & 128 & $51,82 \%$ \\
\hline & Regular & 56 & $22,67 \%$ \\
\hline & Fraco & 09 & $3,64 \%$ \\
\hline & Insatisfatório & 0 & $0,00 \%$ \\
\hline & Total & 247 & $100 \%$ \\
\hline \multirow{6}{*}{$\begin{array}{l}\text { 24. Considerando características } \\
\text { importantes para mim, como } \\
\text { classifico o desempenho dos } \\
\text { meus principais fornecedores } \\
\text { (exemplo: dentais e laboratórios } \\
\text { de prótese); }\end{array}$} & Ótimo & 22 & $8,91 \%$ \\
\hline & Bom & 150 & $60,73 \%$ \\
\hline & Regular & 63 & $25,51 \%$ \\
\hline & Fraco & 10 & $4,05 \%$ \\
\hline & Insatisfatório & 02 & $0,81 \%$ \\
\hline & Total & 247 & $100 \%$ \\
\hline \multirow{6}{*}{$\begin{array}{l}\text { 29. Quanto às documentações } \\
\text { legais, como por exemplo ISS, } \\
\text { alvará de funcionamento da } \\
\text { vigilância sanitária municipal, } \\
\text { etc., classifico a situação do local } \\
\text { onde trabalho como sendo. }\end{array}$} & Ótimo & 146 & $59,11 \%$ \\
\hline & Bom & 68 & $27,53 \%$ \\
\hline & Regular & 23 & $9,31 \%$ \\
\hline & Fraco & 08 & $3,24 \%$ \\
\hline & Insatisfatório & 02 & $0,81 \%$ \\
\hline & Total & 247 & $100 \%$ \\
\hline
\end{tabular}


Cerca de $20 \%$ dos profissionais classificam as características da equipe como sendo de regular a insatisfatória, entretanto a comunicação se mostrou como um ponto forte, sendo bem avaliada pelos respondentes (Tabela 5.10).

Tabela 5.10 - Frequência de resposta para o instrumento DMS-BR (dimensão: equipe)

\begin{tabular}{l|c|c|c}
\hline \multicolumn{2}{c|}{ Equipe } & $\begin{array}{c}\text { Número } \\
\text { absoluto }\end{array}$ & Porcentagem \\
\hline 08. Classifico a qualidade & Ótimo & 77 & $31,17 \%$ \\
da comunicação com a & Bom & 136 & $55,06 \%$ \\
equipe com quem trabalho & Regular & 25 & $10,12 \%$ \\
como sendo; & Fraco & 09 & $3,64 \%$ \\
& Insatisfatório & 0 & $0,00 \%$ \\
\cline { 2 - 4 } & Total & 247 & $100 \%$ \\
\hline 13. Considerando as & Ótimo & 42 & $17,00 \%$ \\
características que julgo & Bom & 154 & $62,35 \%$ \\
importante, classifico o & Regular & 43 & $17,41 \%$ \\
trabalho de meus & Fraco & 05 & $2,02 \%$ \\
funcionários e/ou equipe & Insatisfatório & 03 & $1,21 \%$ \\
como sendo; & Total & 247 & $100 \%$ \\
\cline { 2 - 4 } & Ótimo & 60 & $24,29 \%$ \\
\hline 36. Considero a atenção & Bom & 143 & $57,89 \%$ \\
dada aos comentários ou & Regular & 37 & $14,98 \%$ \\
sugestões sobre o & Fraco & 06 & $2,43 \%$ \\
funcionamento do & Insatisfatório & 01 & $0,40 \%$ \\
\cline { 2 - 4 } consultório feitos por meus & Total & 247 & $100 \%$ \\
funcionários, membros de & & & \\
minha equipe ou paciente & como sendo. & & \\
\hline
\end{tabular}


Quando se trata da carreira, a grande maioria dos profissionais afirmaram que os últimos cursos a que assistiram são bons ou ótimos e que seus consultórios oferecem uma situação ergonômica de trabalho. Além disso, mais de $66 \%$ da amostra consideram a profissão como sendo ótima ou boa, sendo que mais de $14 \%$ a classificam como fraca ou insatisfatória (Tabela 5.11).

Tabela 5.11 - Frequência de resposta para o instrumento DMS-BR (dimensão: carreira)

\begin{tabular}{l|c|c|c}
\hline \multicolumn{2}{c|}{ Carreira } & $\begin{array}{c}\text { Número } \\
\text { absoluto }\end{array}$ & Porcentagem \\
\hline 09. Em relação à minha vida & Ótimo & 30 & $12,15 \%$ \\
profissional, considero o & Bom & 119 & $48,18 \%$ \\
planejamento de estratégias & Regular & 67 & $27,13 \%$ \\
para atingir meus objetivos & Fraco & 23 & $9,31 \%$ \\
futuros como sendo; & Insatisfatório & 8 & $3,24 \%$ \\
\cline { 2 - 4 } & Total & 247 & $100 \%$ \\
\hline 17. Analisando os quatro últimos & Ótimo & 85 & $34,41 \%$ \\
anos, considero a quantidade e & Bom & 105 & $42,51 \%$ \\
a qualidade dos cursos que & Regular & 38 & $15,38 \%$ \\
frequentei como sendo; & Fraco & 15 & $6,07 \%$ \\
& Insatisfatório & 4 & $1,62 \%$ \\
\cline { 2 - 4 } & Total & 247 & $100 \%$ \\
\hline 19. Analisando a ergonomia do & Ótimo & 100 & $40,49 \%$ \\
local de atendimento, considero & Bom & 116 & $46,96 \%$ \\
a disposição dos móveis, & Regular & 22 & $8,91 \%$ \\
equipamentos e materiais como & Fraco & 4 & $1,62 \%$ \\
sendo; & Insatisfatório & 5 & $2,02 \%$ \\
\cline { 2 - 4 } & Total & 247 & $100 \%$ \\
\hline 27. Considero a profissão de & Ótimo & 60 & $24,29 \%$ \\
cirurgião-dentista como sendo. & Bom & 104 & $42,11 \%$ \\
& Regular & 48 & $19,43 \%$ \\
& Fraco & 20 & $8,10 \%$ \\
& Insatisfatório & 15 & $6,07 \%$ \\
\cline { 2 - 4 } & Total & 247 & $100 \%$ \\
\hline
\end{tabular}


Quanto à produtividade e seus resultados, mais da metade da amostra dos profissionais declaram que conhecem técnicas de negociação ou possuem poder de convencimento, consideram-se produtivos e eficientes, fazem controle do fluxo de pacientes e consideram como bom e ótimo o número de pacientes que recebem mensalmente, por meio do boca a boca (Tabela 5.12).

Tabela 5.12 - Frequência de resposta para o instrumento DMS-BR (dimensão: produtividade)

\begin{tabular}{|c|c|c|c|}
\hline \multicolumn{2}{|l|}{ Produtividade } & \multirow{3}{*}{$\begin{array}{c}\begin{array}{c}\text { Número } \\
\text { absoluto }\end{array} \\
43 \\
103\end{array}$} & \multirow{2}{*}{$\frac{\text { Porcentagem }}{17,41 \%}$} \\
\hline \multirow{6}{*}{$\begin{array}{l}\text { 14. Em relação à venda de } \\
\text { meus serviços, classifico o } \\
\text { meu conhecimento sobre } \\
\text { técnicas de negociação e/ou } \\
\text { poder de convencimento } \\
\text { sobre meus clientes como } \\
\text { sendo; }\end{array}$} & Ótimo & & \\
\hline & Bom & & $41,70 \%$ \\
\hline & Regular & 73 & $29,55 \%$ \\
\hline & Fraco & 21 & $8,50 \%$ \\
\hline & Insatisfatório & 7 & $2,83 \%$ \\
\hline & Total & 247 & $100 \%$ \\
\hline \multirow{6}{*}{$\begin{array}{l}\text { 22. Considerando minha } \\
\text { produtividade e eficiência de } \\
\text { trabalho, classifico minha } \\
\text { situação como; }\end{array}$} & Ótimo & 58 & $23,48 \%$ \\
\hline & Bom & 152 & $61,54 \%$ \\
\hline & Regular & 34 & $13,77 \%$ \\
\hline & Fraco & 2 & $0,81 \%$ \\
\hline & Insatisfatório & 1 & $0,40 \%$ \\
\hline & Total & 247 & $100 \%$ \\
\hline \multirow{6}{*}{$\begin{array}{l}\text { 32. Classifico o controle de } \\
\text { fluxo de pacientes (retornos, } \\
\text { novos, faltas, atrasos) do } \\
\text { local que trabalho como } \\
\text { sendo; }\end{array}$} & Ótimo & 33 & $13,36 \%$ \\
\hline & Bom & 104 & $42,11 \%$ \\
\hline & Regular & 72 & $29,15 \%$ \\
\hline & Fraco & 34 & $13,77 \%$ \\
\hline & Insatisfatório & 4 & $1,62 \%$ \\
\hline & Total & 247 & $100 \%$ \\
\hline \multirow{6}{*}{$\begin{array}{l}\text { 33. Considerando a } \\
\text { quantidade de pacientes que } \\
\text { recebo mensalmente por } \\
\text { meio do boca a boca ou } \\
\text { indicação de colegas, como } \\
\text { classifico a situação do meu } \\
\text { consultório. }\end{array}$} & Ótimo & 46 & $18,62 \%$ \\
\hline & Bom & 121 & $48,99 \%$ \\
\hline & Regular & 56 & $22,67 \%$ \\
\hline & Fraco & 19 & $7,69 \%$ \\
\hline & Insatisfatório & 5 & $2,02 \%$ \\
\hline & Total & 247 & $100 \%$ \\
\hline
\end{tabular}


5.1.3.3 Fase 03: média dos resultados por dimensão da escala DMS-BR

A média obtida pelos participantes foi de $3,77(\mathrm{DP}=0,44)$, de uma escala de 1 a 5. Os valores para cada dimensão podem ser analisados na tabela 5.13, sendo a maior média para a dimensão ponto e a menor para a dimensão marketing.

Tabela 5.13 - Valores de Média e Desvio Padrão para cada dimensão do instrumento DMS-BR

\begin{tabular}{lccc}
\hline Dimensões & Média & $\begin{array}{c}\text { Desvio } \\
\text { Padrão }\end{array}$ & Mín/Máx \\
\hline Ponto & 4,23 & 0,54 & $2,33 / 5,00$ \\
Qualidade & 4,10 & 0,47 & $2,33 / 5,00$ \\
Equipe & 4,02 & 0,56 & $1,00 / 5,00$ \\
Carreira & 3,87 & 0,64 & $1,50 / 5,00$ \\
Paciente & 3,85 & 0,53 & $2,20 / 5,00$ \\
Produtividade & 3,73 & 0,64 & $1,75 / 5,00$ \\
Concorrência & 3,68 & 0,62 & $1,67 / 5,00$ \\
Financeiro & 3,47 & 0,72 & $1,20 / 5,00$ \\
Marketing & 3,10 & 0,71 & $1,20 / 5,00$ \\
\hline Total & 3,77 & 0,44 & $2,24 / 4,84$ \\
\hline
\end{tabular}


A tabela 5.14 apresenta os itens para a formação do indicador de uso e conhecimento de ferramentas de marketing/gestão da dimensão ponto, cuja maior pontuação foi recebida para a avaliação do acesso ao consultório ou à clínica.

Tabela 5.14 - Média das respostas para o instrumento DMS-BR para as questões da dimensão ponto

\begin{tabular}{lccc}
\hline \multicolumn{1}{c}{ Ponto } & Média & $\begin{array}{l}\text { Desvio } \\
\text { Padrão }\end{array}$ & Mín/Máx \\
\hline $\begin{array}{l}\text { 01. Como eu classifico a facilidade de } \\
\begin{array}{l}\text { acesso da clínica ou consultório que } \\
\text { trabalho; }\end{array}\end{array}$ & 4,38 & 0,69 & $1,00 / 5,00$ \\
$\begin{array}{l}\text { 34. Considerando o seu público-alvo, } \\
\text { você avalia a decoração e o conforto de } \\
\text { sua sala de espera como sendo; }\end{array}$ & 4,01 & 0,81 & $1,00 / 5,00$ \\
$\begin{array}{l}\text { 37. Classifico o estado de conservação e } \\
\text { o visual da(s) sala(s) de atendimento } \\
\text { como sendo. }\end{array}$ & 4,28 & 0,69 & $2,00 / 5,00$ \\
\hline
\end{tabular}


Em relação a dimensão paciente, a tabela 5.15 demonstra que a menor média encontrada foi para o quesito que mede as estratégias de comunicação com o paciente, como cartas, e-mails e telefone. Pode-se perceber também que a maior média relatada refere-se à pontualidade do profissional em relação ao horário de agendamento da consulta.

Tabela 5.15 - Média das respostas para o instrumento DMS-BR para as questões da dimensão paciente

\begin{tabular}{lccc}
\hline \multicolumn{1}{c}{ Paciente } & Média & $\begin{array}{l}\text { Desvio } \\
\text { Padrão }\end{array}$ & Mín/Máx \\
\hline $\begin{array}{l}\text { 02. Considerando as estratégias de } \\
\text { relacionamento com seus pacientes, como } \\
\text { ligações para clientes antigos, envio de } \\
\text { mala direta, envio de e-mail, entre outras, } \\
\text { considero a minha situação como; }\end{array}$ & 2,86 & 1,08 & $1,00 / 5,00$ \\
$\begin{array}{l}\text { 06. Considerando a atenção que dedico ao } \\
\text { meu paciente antes, durante e após a } \\
\text { consulta, classifico meu atendimento como } \\
\text { sendo; }\end{array}$ & 4,43 & 0,63 & $2,00 / 5,00$ \\
$\begin{array}{l}\text { 15. Quanto ao cumprimento do horário das } \\
\text { consultas agendadas, considero minha } \\
\text { pontualidade como sendo; }\end{array}$ & & & \\
$\begin{array}{l}\text { 30. Como classifico a minha capacidade } \\
\text { (ou de minha equipe) de fidelizar os }\end{array}$ & & & \\
pacientes; & 3,48 & 0,70 & $1,00 / 5,00$ \\
$\begin{array}{l}\text { 31. Considerando as formas de avaliar a } \\
\text { satisfação dos meus clientes, classifico a } \\
\text { minha situação como sendo. }\end{array}$ & 3,57 & 0,90 & \\
\hline
\end{tabular}


A tabela 5.16 revela menor média da dimensão financeiro para a questão referente ao planejamento de uma futura aposentadoria. A maior média foi encontrada para a pergunta ao profissional acerca dos gastos fixos e variáveis referentes ao consultório.

Tabela 5.16 - Média das respostas para o instrumento DMS-BR para as questões da dimensão financeiro

\begin{tabular}{lccc}
\hline \multicolumn{1}{c}{ Financeiro } & Média & $\begin{array}{l}\text { Desvio } \\
\text { Padrão }\end{array}$ & Mín/Máx \\
\hline $\begin{array}{l}\text { 03. Considerando pesquisa de preço } \\
\text { antes de uma compra importante } \\
\text { reserva financeira para a compra de } \\
\text { materiais e equipamentos, avalio meu } \\
\text { comportamento como sendo; }\end{array}$ & 3,54 & 0,93 & $1,00 / 5,00$ \\
$\begin{array}{l}\text { 23. Classifico o meu planejamento } \\
\text { financeiro atual para uma futura } \\
\text { aposentadoria como sendo; }\end{array}$ & 3,04 & 1,15 & $1,00 / 5,00$ \\
$\begin{array}{l}\text { 25. Considerando que o preço deve estar } \\
\text { de acordo com seus custos fixos e }\end{array}$ & & & \\
$\begin{array}{l}\text { variáveis, como você considera a } \\
\text { formação dos preços cobrados em seu } \\
\text { consultório; }\end{array}$ & 3,63 & 0,82 & $1,00 / 5,00$ \\
$\begin{array}{l}\text { 26. Classifico o controle financeiro que } \\
\text { faço em meu consultório ou referente a } \\
\text { ganhos/gastos profissionais como sendo; }\end{array}$ & 3,49 & 0,97 & $1,00 / 5,00$ \\
$\begin{array}{l}\text { 38. Como você classifica o seu } \\
\text { conhecimento sobre os gastos fixos e } \\
\text { variáveis referentes ao seu consultório. }\end{array}$ & 3,67 & 1,00 & $1,00 / 5,00$ \\
\hline
\end{tabular}


A tabela 5.17 apresenta os itens para a formação do indicador de uso e conhecimento de ferramentas de marketing da dimensão marketing e revela a maior média para a pergunta sobre o conhecimento dos profissionais em relação ao público-alvo. A menor média encontrada refere-se à divulgação dos serviços o meio de mídia impressa ou digital.

Tabela 5.17 - Média das respostas para o instrumento DMS-BR para as questões da dimensão marketing

\begin{tabular}{|c|c|c|c|}
\hline Marketing & Média & $\begin{array}{l}\text { Desvio } \\
\text { Padrão }\end{array}$ & Mín/Máx \\
\hline $\begin{array}{l}\text { 04. Quanto as estratégias para atrair } \\
\text { novos clientes para o consultório ou } \\
\text { clínica que trabalho, como anúncios, } \\
\text { parcerias, divulgação em sites de } \\
\text { pesquisa/busca, entre outras, considero } \\
\text { minha situação como sendo; }\end{array}$ & 2,72 & 1,06 & $1,00 / 5,00$ \\
\hline $\begin{array}{l}\text { 10. Como avalio o meu conhecimento em } \\
\text { áreas como gestão, marketing e } \\
\text { administração; }\end{array}$ & 2,77 & 1,17 & $1,00 / 5,00$ \\
\hline $\begin{array}{l}\text { 11. Considerando a divulgação de meus } \\
\text { serviços por meio de material impresso ou } \\
\text { digital, incluindo redes sociais, site, folder, } \\
\text { anúncios considero minha situação como } \\
\text { sendo; }\end{array}$ & 2,63 & 1,07 & $1,00 / 5,00$ \\
\hline $\begin{array}{l}\text { 20. Considerando minha habilidade e } \\
\text { dedicação em relação a parte } \\
\text { administrativa da profissão, classifico } \\
\text { minha atuação como sendo; }\end{array}$ & 3,48 & 0,82 & $1,00 / 5,00$ \\
\hline $\begin{array}{l}\text { 35. Considero o meu conhecimento sobre } \\
\text { o perfil de pacientes que atendo, ou seja, } \\
\text { meu público-alvo, como sendo. }\end{array}$ & 3,90 & 0,66 & $1,00 / 5,00$ \\
\hline
\end{tabular}


Em relação a dimensão concorrência, a tabela 5.18 mostra que a classificação quanto a vantagem competitiva e conhecimento sobre pontos fracos e fortes obtiveram as maiores médias.

Tabela 5.18 - Média das respostas para o instrumento DMS-BR para as questões da dimensão concorrência

\begin{tabular}{lccc}
\hline \multicolumn{1}{c}{ Concorrência } & Média & $\begin{array}{l}\text { Desvio } \\
\text { Padrão }\end{array}$ & Mín/Máx \\
\hline $\begin{array}{l}\text { 07. Classifico minha vantagem } \\
\text { competitiva em relação aos meus } \\
\text { principais concorrentes como sendo; }\end{array}$ & 3,82 & 0,77 & $1,00 / 5,00$ \\
$\begin{array}{l}\text { 12. Classifico o meu conhecimento sobre } \\
\text { os meus concorrentes como sendo; }\end{array}$ & 3,34 & 1,05 & $1,00 / 5,00$ \\
$\begin{array}{l}\text { 28. Classifico os meus conhecimentos } \\
\text { sobre os pontos fracos e pontos fortes do } \\
\text { consultório ou clínica em que trabalho } \\
\text { como sendo. }\end{array}$ & 3,87 & 0,73 & $1,00 / 5,00$ \\
\hline
\end{tabular}


Para a dimensão qualidade, foram encontradas as maiores médias para a pergunta sobre a qualidade da proteção individual medida por meio do uso de EPIs (Tabela 5.19) e a situação da documentação legal do consultório.

Tabela 5.19 - Média das respostas para o instrumento DMS-BR para as questões da dimensão qualidade

\begin{tabular}{|c|c|c|c|}
\hline Qualidade & Média & $\begin{array}{l}\text { Desvio } \\
\text { Padrão }\end{array}$ & Mín/Máx \\
\hline $\begin{array}{l}\text { 05. Considerando a qualidade e } \\
\text { organização das informações, considero } \\
\text { o prontuário dos meus pacientes como } \\
\text { sendo; }\end{array}$ & 3,84 & 0,91 & $1,00 / 5,00$ \\
\hline $\begin{array}{l}\text { 16. Considerando o uso de gorro, } \\
\text { máscara, luva, óculos e avental, avalio } \\
\text { minha proteção individual como sendo; }\end{array}$ & 4,63 & 0,60 & $2,00 / 5,00$ \\
\hline $\begin{array}{l}\text { 18. Analisando a organização do meu } \\
\text { consultório, incluindo arquivos, fichas, } \\
\text { materiais e equipamentos, classifico a } \\
\text { minha situação como sendo; }\end{array}$ & 4,08 & 0,78 & $1,00 / 5,00$ \\
\hline $\begin{array}{l}\text { 21. Considerando aspectos como } \\
\text { armazenamento, disponibilidade, } \\
\text { desperdício e planejamento de compra, } \\
\text { considero o controle do estoque de } \\
\text { materiais do local onde trabalho como } \\
\text { sendo; }\end{array}$ & 3,91 & 0,76 & $2,00 / 5,00$ \\
\hline $\begin{array}{l}\text { 24. Considerando características } \\
\text { importantes para mim, como classifico o } \\
\text { desempenho dos meus principais } \\
\text { fornecedores (exemplo: dentais e } \\
\text { laboratórios de prótese); }\end{array}$ & 3,72 & 0,71 & $1,00 / 5,00$ \\
\hline $\begin{array}{l}\text { 29. Quanto às documentações legais, } \\
\text { como por exemplo ISS, alvará de } \\
\text { funcionamento da vigilância sanitária } \\
\text { municipal, etc., classifico a situação do } \\
\text { local onde trabalho como sendo. }\end{array}$ & 4,40 & 0,84 & $1,00 / 5,00$ \\
\hline
\end{tabular}


Dentre as respostas para a dimensão equipe, nota-se as maiores médias para a qualidade da comunicação e a atenção dada aos comentários e sugestões sobre questões referentes ao funcionamento do consultório (Tabela 5.20).

Tabela 5.20 - Média das respostas para o instrumento DMS-BR para as questões da dimensão equipe

\begin{tabular}{lccc}
\hline \multicolumn{1}{c}{ Equipe } & Média & $\begin{array}{l}\text { Desvio } \\
\text { Padrão }\end{array}$ & Mín/Máx \\
\hline $\begin{array}{l}\text { 08. Classifico a qualidade da comunicação } \\
\text { com a equipe com quem trabalho como } \\
\text { sendo; }\end{array}$ & 4,13 & 0,73 & $2,00 / 5,00$ \\
$\begin{array}{l}\text { 13. Considerando as características que } \\
\text { julgo importantes, classifico o trabalho de } \\
\text { meus funcionários e/ou equipe como }\end{array}$ & 3,91 & 0,72 & $1,00 / 5,00$ \\
sendo; & & & \\
$\begin{array}{l}\text { 36. Considero a atenção dada aos } \\
\text { comentários ou sugestões sobre o } \\
\text { funcionamento do consultório feitos por } \\
\text { meus funcionários, membros de minha }\end{array}$ & 3,03 & 0,72 & $1,00 / 5,00$ \\
equipe ou paciente como sendo. & & & \\
\hline
\end{tabular}


A análise da tabela 5.21, que apresenta os itens para a formação do indicador de uso e conhecimento de ferramentas de marketing/gestão da dimensão carreira, permite observar que a pergunta relacionada ao planejamento de estratégias para atingir objetivos futuros obteve a menor média, seguida pela pergunta sobre como o profissional considera a profissão.

Tabela 5.21 - Média das respostas para o instrumento DMS-BR para as questões da dimensão carreira

\begin{tabular}{lccc}
\hline \multicolumn{1}{c}{ Carreira } & Média & $\begin{array}{l}\text { Desvio } \\
\text { Padrão }\end{array}$ & Mín/Máx \\
\hline $\begin{array}{l}\text { 09. Em relação à minha vida profissional, } \\
\text { considero o planejamento de estratégias } \\
\text { para atingir meus objetivos futuros como } \\
\text { sendo; }\end{array}$ & 3,56 & 0,93 & $1,00 / 5,00$ \\
$\begin{array}{l}\text { 17. Analisando os quatro últimos anos, } \\
\text { considero a quantidade e a qualidade dos } \\
\text { cursos que frequentei como sendo; }\end{array}$ & 4,02 & 0,94 & $1,00 / 5,00$ \\
$\begin{array}{l}\text { 19. Analisando a ergonomia do local de } \\
\text { atendimento, considero a disposição dos } \\
\text { móveis, equipamentos e materiais como } \\
\text { sendo; }\end{array}$ & 4,22 & 0,83 & $1,00 / 5,00$ \\
$\begin{array}{l}\text { 27. Considero a profissão de cirurgião- } \\
\text { dentista como sendo. }\end{array}$ & 3,70 & 1,10 & $1,00 / 5,00$ \\
\hline
\end{tabular}


Para a dimensão produtividade, a questão sobre produtividade e eficiência mostrou-se com a maior média, seguida pela boa avaliação da quantidade de pacientes recebidos mensalmente por meio do boca a boca (Tabela 5.22).

Tabela 5.22 - Média das respostas para o instrumento DMS-BR para as questões da dimensão produtividade

\begin{tabular}{lccc}
\hline \multicolumn{1}{c}{ Produtividade } & Média & $\begin{array}{l}\text { Desvio } \\
\text { Padrão }\end{array}$ & Mín/Máx \\
\hline $\begin{array}{l}\text { 14. Em relação à venda de meus } \\
\text { serviços, classifico o meu conhecimento } \\
\text { sobre técnicas de negociação e/ou poder } \\
\text { de convencimento sobre meus clientes } \\
\text { como sendo; }\end{array}$ & 3,62 & 0,96 & $1,00 / 5,00$ \\
$\begin{array}{l}\text { 22. Considerando minha produtividade e } \\
\text { eficiência de trabalho, classifico minha } \\
\text { situação como; }\end{array}$ & 4,06 & 0,66 & $1,00 / 5,00$ \\
$\begin{array}{l}\text { 32. Classifico o controle de fluxo de } \\
\text { pacientes (retornos, novos, faltas, } \\
\text { atrasos) do local que trabalho como } \\
\text { sendo; }\end{array}$ & & & \\
$\begin{array}{l}\text { 33. Considerando a quantidade de } \\
\text { pacientes que recebo mensalmente por } \\
\text { meio do boca a boca ou indicação de } \\
\text { colegas, como classifico a situação do } \\
\text { meu consultório. }\end{array}$ & 3,51 & 0,94 & $1,00 / 5,00$ \\
\hline
\end{tabular}

5.1.3.4 Análise psicométrica da escala DMS-BR por dimensão

A consistência interna do questionário foi considerada adequada (Cronbach$a=0,925)$, sendo que os valores das dimensões - financeiro (Cronbach-a=0,792), marketing (Cronbach-a $=0,780)$, carreira (Cronbach- $a=0,780)$, produtividade (Cronbach-a $=0,704)$, equipe (Cronbach- $a=0,666)$, qualidade (Cronbach-a=0,654), ponto (Cronbach-a $=0,589)$, paciente (Cronbach-a $=0,632)$ e concorrência (Cronbach-a $=0,530)$ - foram considerados igualmente adequados. Os valores para cada questão podem ser vistos nas tabelas 5.23 a 5.31 . 
A dimensão ponto, representado na tabela 5.23, mostra que todas as questões se apresentaram com forte correlação entre si.

Tabela 5.23 - Análise psicométrica da dimensão ponto do instrumento DMS-BR

\begin{tabular}{lc|c}
\hline \multicolumn{1}{c}{ Questões referentes a dimensão ponto } & Correlação & $\begin{array}{r}\text { Coeficiente } \\
\text { alpha Cronbach }\end{array}$ \\
\hline $\begin{array}{l}\text { 01. Como eu classifico a facilidade de acesso } \\
\text { da clínica ou consultório que trabalho; }\end{array}$ & 0,622 & \\
$\begin{array}{l}\text { 34. Considerando o seu público-alvo, você } \\
\text { avalia a decoração e o conforto de sua sala de } \\
\text { espera como sendo; }\end{array}$ & 0,827 & 0,589 \\
$\begin{array}{l}\text { 37. Classifico o estado de conservação e o } \\
\text { visual da(s) sala(s) de atendimento como } \\
\text { sendo. }\end{array}$ & 0,765 & \\
\hline
\end{tabular}


A dimensão paciente também se apresentou com grande variabilidade entre si, sendo a questão sobre o cumprimento do horário apresentou a menor relação, embora mostre relação com a dimensão.

Tabela 5.24 - Análise psicométrica da dimensão paciente do instrumento DMS-BR

\begin{tabular}{|c|c|c|}
\hline Questões referentes a dimensão paciente & Correlação & $\begin{array}{c}\text { Coeficiente } \\
\text { alpha Cronbach }\end{array}$ \\
\hline $\begin{array}{l}\text { 02. Considerando as estratégias de } \\
\text { relacionamento com seus pacientes, como } \\
\text { ligações para clientes antigos, envio de mala } \\
\text { direta, envio de e-mail, entre outras, considero a } \\
\text { minha situação como; }\end{array}$ & 0,7265 & \\
\hline $\begin{array}{l}\text { 06. Considerando a atenção que dedico ao meu } \\
\text { paciente antes, durante e após a consulta, } \\
\text { classifico meu atendimento como sendo; }\end{array}$ & 0,5853 & \\
\hline $\begin{array}{l}\text { 15. Quanto ao cumprimento do horário das } \\
\text { consultas agendadas, considero minha } \\
\text { pontualidade como sendo; }\end{array}$ & 0,4519 & 0,632 \\
\hline $\begin{array}{l}\text { 30. Como classifico a minha capacidade (ou de } \\
\text { minha equipe) de fidelizar os pacientes; }\end{array}$ & 0,6934 & \\
\hline $\begin{array}{l}\text { 31. Considerando as formas de avaliar a } \\
\text { satisfação dos meus clientes, classifico a minha } \\
\text { situação como sendo. }\end{array}$ & 0,7122 & \\
\hline
\end{tabular}


As perguntas da dimensão financeiro se mostram com forte correlação entre si, com destaque para a pergunta sobre o controle financeiro realizado no consultório, considerando-se os ganhos e gastos profissionais, que apresentaram a maior correlação.

Tabela 5.25 - Análise psicométrica da dimensão financeiro do instrumento DMS-BR

\begin{tabular}{lcc}
\hline \multicolumn{1}{c}{ Questões referentes a dimensão financeiro } & Correlação & $\begin{array}{c}\text { Coeficiente } \\
\text { alpha Cronbach }\end{array}$ \\
\hline $\begin{array}{l}\text { 03. Considerando pesquisa de preço antes de } \\
\text { uma compra importante e reserva financeira } \\
\text { para a compra de materiais e equipamentos, } \\
\text { avalio meu comportamento como sendo; }\end{array}$ & 0,7078 & \\
$\begin{array}{l}\text { 23. Classifico o meu planejamento financeiro } \\
\text { atual para uma futura aposentadoria como } \\
\text { sendo; }\end{array}$ & 0,7545 & \\
$\begin{array}{l}\text { 25. Considerando que o preço deve estar de } \\
\text { acordo com seus custos fixos e variáveis, como } \\
\text { você considera a formação dos preços } \\
\text { cobrados em seu consultório; }\end{array}$ & \\
$\begin{array}{l}\text { 26. Classifico o controle financeiro que faço em } \\
\text { meu consultório ou referente a ganhos/gastos } \\
\text { profissionais como sendo; }\end{array}$ & 0,6637 \\
$\begin{array}{l}\text { 38. Como você classifica o seu conhecimento } \\
\text { sobre os gastos fixos e variáveis referentes ao } \\
\text { seu consultório. }\end{array}$ & 0,8210 & \\
\hline
\end{tabular}


A relação entre as questões da dimensão marketing variavam bastante entretanto a análise mostra que todas mantêm um bom nível de relação entre si (Tabela 5.26).

Tabela 5.26 - Análise psicométrica da dimensão marketing do instrumento DMS-BR

\begin{tabular}{|c|c|c|}
\hline Questões referentes a dimensão marketing & Correlação & $\begin{array}{c}\text { Coeficiente } \\
\text { alpha Cronbach }\end{array}$ \\
\hline $\begin{array}{l}\text { 04. Quanto as estratégias para atrair novos } \\
\text { clientes para o consultório ou clínica que } \\
\text { trabalho, como anúncios, parcerias, divulgação } \\
\text { em sites de pesquisa/busca, entre outras, } \\
\text { considero minha situação como sendo; }\end{array}$ & 0,8218 & \\
\hline $\begin{array}{l}\text { 10. Como avalio o meu conhecimento em áreas } \\
\text { como gestão, marketing e administração; }\end{array}$ & 0,786 & \\
\hline $\begin{array}{l}\text { 11. Considerando a divulgação de meus } \\
\text { serviços por meio de material impresso ou } \\
\text { digital, incluindo redes sociais, site, folder, } \\
\text { anúncios considero minha situação como } \\
\text { sendo; }\end{array}$ & 0,7998 & 0,780 \\
\hline $\begin{array}{l}\text { 20. Considerando minha habilidade e dedicação } \\
\text { em relação a parte administrativa da profissão, } \\
\text { classifico minha atuação como sendo; }\end{array}$ & 0,6874 & \\
\hline $\begin{array}{l}\text { 35. Considero o meu conhecimento sobre o } \\
\text { perfil de pacientes que atendo, ou seja, meu } \\
\text { público-alvo, como sendo. }\end{array}$ & 0,5220 & \\
\hline
\end{tabular}


As perguntas da dimensão concorrência se mostraram com forte relação entre si, com maior relação para a pergunta acerca do conhecimento da concorrência (Tabela 5.27).

Tabela 5.27 - Análise psicométrica da dimensão concorrência do instrumento DMS-BR

\begin{tabular}{lcc}
\hline Questões referentes a dimensão concorrência & Correlação & $\begin{array}{c}\text { Coeficiente } \\
\text { alpha } \\
\text { Cronbach }\end{array}$ \\
\hline $\begin{array}{l}\text { 07. Classifico minha vantagem competitiva em } \\
\text { relação aos meus principais concorrentes como } \\
\text { sendo; }\end{array}$ & 0,6678 & \\
$\begin{array}{l}\text { 12. Classifico o meu conhecimento sobre os } \\
\text { meus concorrentes como sendo; }\end{array}$ & 0,8013 & 0,530 \\
$\begin{array}{l}\text { 28. Classifico os meus conhecimentos sobre os } \\
\text { pontos fracos e pontos fortes do consultório ou } \\
\text { clínica em que trabalho como sendo. }\end{array}$ & 0,6848 & \\
\hline
\end{tabular}


A questão com menor relação apresentada na Tabela 5.28, para a dimensão Qualidade, foi referente à utilização de EPIs, entretanto, mesmo com um valor de 3,342, pode-se observar uma relação média desta questão com a dimensão.

Tabela 5.28 - Análise psicométrica da dimensão qualidade do instrumento DMS-BR

\begin{tabular}{|c|c|c|}
\hline Questões referentes a dimensão qualidade & Correlação & $\begin{array}{c}\text { Coeficiente } \\
\text { alpha Cronbach }\end{array}$ \\
\hline $\begin{array}{l}\text { 25. Considerando a qualidade e organização } \\
\text { das informações, considero o prontuário dos } \\
\text { meus pacientes como sendo; }\end{array}$ & 0,7301 & \\
\hline $\begin{array}{l}\text { 16. Considerando o uso de gorro, máscara, } \\
\text { luva, óculos e avental, avalio minha proteção } \\
\text { individual como sendo; }\end{array}$ & 0,3432 & \\
\hline $\begin{array}{l}\text { 18. Analisando a organização do meu } \\
\text { consultório, incluindo arquivos, fichas, materiais } \\
\text { e equipamentos, classifico a minha situação } \\
\text { como sendo; }\end{array}$ & 0,7365 & \\
\hline $\begin{array}{l}\text { 21. Considerando aspectos como } \\
\text { armazenamento, disponibilidade, desperdício e } \\
\text { planejamento de compra, considero o controle } \\
\text { do estoque de materiais do local onde trabalho } \\
\text { como sendo; }\end{array}$ & 0,6342 & 0,653 \\
\hline $\begin{array}{l}\text { 24. Considerando características importantes } \\
\text { para mim, como classifico o desempenho dos } \\
\text { meus principais fornecedores (exemplo: dentais } \\
\text { e laboratórios de prótese); }\end{array}$ & 0,5038 & \\
\hline $\begin{array}{l}\text { 29. Quanto às documentações legais, como por } \\
\text { exemplo ISS, alvará de funcionamento da } \\
\text { vigilância sanitária municipal, etc., classifico a } \\
\text { situação do local onde trabalho como sendo. }\end{array}$ & 0,6251 & \\
\hline
\end{tabular}


A relação entre as questões da dimensão equipe se mostraram fortes, como pode-se ser observado na tabela 5.29.

Tabela 5.29 - Análise psicométrica da dimensão equipe do instrumento DMS-BR

\begin{tabular}{lcc}
\hline \multicolumn{1}{c}{ Questões referentes a dimensão equipe } & Correlação & $\begin{array}{c}\text { Coeficiente } \\
\text { alpha Cronbach }\end{array}$ \\
\hline $\begin{array}{l}\text { 08. Classifico a qualidade da comunicação com } \\
\text { a equipe com quem trabalho como sendo; }\end{array}$ & 0,8107 & \\
$\begin{array}{l}\text { 13. Considerando as características que julgo } \\
\text { importantes, classifico o trabalho de meus } \\
\text { funcionários e/ou equipe como sendo; }\end{array}$ & 0,7727 & 0,666 \\
$\begin{array}{l}\text { 36. Considero a atenção dada aos comentários } \\
\text { ou sugestões sobre o funcionamento do } \\
\text { consultório feitos por meus funcionários, } \\
\text { membros de minha equipe ou paciente como } \\
\text { sendo. }\end{array}$ & & \\
\hline
\end{tabular}

A dimensão carreira apresentou om nível de correlação entre as perguntas, sendo que a menor relação foi referente à pergunta sobre a ergonomia.

Tabela 5.30 - Análise psicométrica da dimensão carreira do instrumento DMS-BR

\begin{tabular}{lcc}
\hline \multicolumn{1}{c}{ Questões referentes a dimensão carreira } & Correlação & $\begin{array}{c}\text { Coeficiente } \\
\text { alpha } \\
\text { Cronbach }\end{array}$ \\
\hline $\begin{array}{l}\text { 09. Em relação à minha vida profissional, } \\
\text { considero o planejamento de estratégias para } \\
\text { atingir meus objetivos futuros como sendo; }\end{array}$ & 0,7417 & \\
$\begin{array}{l}\text { 17. Analisando os quatro últimos anos, } \\
\text { considero a quantidade e a qualidade dos } \\
\text { cursos que frequentei como sendo; }\end{array}$ & 0,6433 & 0,780 \\
$\begin{array}{l}\text { 19. Analisando a ergonomia do local de } \\
\text { atendimento, considero a disposição dos } \\
\text { móveis, equipamentos e materiais como sendo; }\end{array}$ & 0,6326 & \\
$\begin{array}{l}\text { 27. Considero a profissão de cirurgião-dentista } \\
\text { como sendo. }\end{array}$ & 0,6821 & \\
\hline
\end{tabular}


Referente a dimensão produtividade, todas as questões se mostraram com um nível forte de relação entre si, sendo a mais alta relação apresentada pela pergunta sobre a quantidade de pacientes recebidos mensalmente por meio de indicação de outros colegas ou boca a boca.

Tabela 5.31 - Análise psicométrica da dimensão produtividade do instrumento DMS-BR

\begin{tabular}{lcc}
\hline Questões referentes a dimensão produtividade & Correlação & $\begin{array}{c}\text { Coeficiente } \\
\text { alpha } \\
\text { Cronbach }\end{array}$ \\
\hline $\begin{array}{l}\text { 14. Em relação à venda de meus serviços, } \\
\text { classifico o meu conhecimento sobre técnicas } \\
\text { de negociação e/ou poder de convencimento } \\
\text { sobre meus clientes como sendo; }\end{array}$ & 0,7217 \\
$\begin{array}{l}\text { 22. Considerando minha produtividade e } \\
\text { eficiência de trabalho, classifico minha situação } \\
\text { como; }\end{array}$ & 0,6705 \\
$\begin{array}{l}\text { 32. Classifico o controle de fluxo de pacientes } \\
\text { (retornos, novos, faltas, atrasos) do local que } \\
\text { trabalho como sendo; }\end{array}$ & \\
$\begin{array}{l}\text { 33. Considerando a quantidade de pacientes } \\
\text { que recebo mensalmente por meio do boca a } \\
\text { boca ou indicação de colegas, como classifico a } \\
\text { situação do meu consultório. }\end{array}$ & 0,7484 \\
\hline
\end{tabular}

5.1.3.5 Correlação das dimensões que compõem o instrumento DMS-BR

A correlação entre as dimensões da escala DMS-BR e o questionário como um todo pode ser visualizada na tabela abaixo (Tabela 5.32), sendo que o maior índice foi obtido pela dimensão paciente e o menor para a dimensão ponto. 
Tabela 5.32 - Correlação de cada uma das dimensões da escala DMS-BR em relação ao questionário.

\begin{tabular}{c|c}
\hline Paciente & 0,8101 \\
Produtividade & 0,7986 \\
Financeiro & 0,7915 \\
Marketing & 0,7614 \\
Carreira & 0,7339 \\
Equipe & 0,7050 \\
Concorrência & 0,7050 \\
Qualidade & 0,6994 \\
Ponto & 0,6062 \\
\hline
\end{tabular}

\subsection{SATISFAÇÃO PROFISSIONAL}

Os resultados da aplicação da escala DSS, compostos pela frequência de respostas entre os participantes da pesquisa, pontuação média para cada pergunta e para o bloco serão apresentados nos tópicos a seguir.

\subsubsection{Distribuição de respostas da escala DSS}

A partir do bloco de satisfação geral, é possível observar que quase a metade dos cirurgiões-dentistas não consideram que a profissão preenche as suas aspirações com a carreira, entretanto, quase 60\% discordam de que gostariam de deixar a profissão para exercer outra atividade. Quase metade deles concordam que tomariam a mesma decisão de fazer Odontologia e se declaram extremamente satisfeitos com a profissão (Tabela 5.33). 
Tabela 5.33 - Frequência de resposta para o questionário satisfação no trabalho (bloco: satisfação geral)

\begin{tabular}{|c|c|c|c|}
\hline \multicolumn{2}{|c|}{ Satisfação geral com o emprego/trabalho } & \multirow{2}{*}{$\begin{array}{l}\text { Número } \\
\text { absoluto }\end{array}$} & \multirow{2}{*}{$\begin{array}{l}\text { Porcentagem } \\
14,57 \%\end{array}$} \\
\hline \multirow{6}{*}{$\begin{array}{l}\text { 05. A odontologia preenche } \\
\text { minhas atuais aspirações } \\
\text { com a carreira; }\end{array}$} & Discordo fortemente & & \\
\hline & Discordo & 39 & $34,41 \%$ \\
\hline & Neutro & 49 & $19,84 \%$ \\
\hline & Concordo & 85 & $15,79 \%$ \\
\hline & Concordo fortemente & 36 & $15,38 \%$ \\
\hline & Total & 247 & $100 \%$ \\
\hline \multirow{6}{*}{$\begin{array}{l}\text { 06. Gostaria de deixar o } \\
\text { meu emprego/trabalho para } \\
\text { fazer outra coisa; }\end{array}$} & Discordo fortemente & 80 & $32,39 \%$ \\
\hline & Discordo & 67 & $27,13 \%$ \\
\hline & Neutro & 48 & $19,43 \%$ \\
\hline & Concordo & 28 & $11,34 \%$ \\
\hline & Concordo fortemente & 24 & $9,72 \%$ \\
\hline & Total & 247 & $100 \%$ \\
\hline \multirow{6}{*}{$\begin{array}{l}\text { 09. Eu pareço mais } \\
\text { satisfeito/a com meu } \\
\text { trabalho/emprego do que } \\
\text { realmente estou; }\end{array}$} & Discordo fortemente & 20 & $8,10 \%$ \\
\hline & Discordo & 78 & $31,58 \%$ \\
\hline & Neutro & 44 & $17,81 \%$ \\
\hline & Concordo & 91 & $36,84 \%$ \\
\hline & Concordo fortemente & 14 & $5,67 \%$ \\
\hline & Total & 247 & $100 \%$ \\
\hline \multirow{6}{*}{$\begin{array}{l}\text { 12. Sabendo o que eu sei } \\
\text { hoje, eu teria tomado a } \\
\text { mesma decisão de fazer } \\
\text { odontologia novamente; }\end{array}$} & Discordo fortemente & 43 & $17,41 \%$ \\
\hline & Discordo & 45 & $18,22 \%$ \\
\hline & Neutro & 44 & $17,81 \%$ \\
\hline & Concordo & 71 & $28,74 \%$ \\
\hline & Concordo fortemente & 44 & $17,81 \%$ \\
\hline & Total & 247 & $100 \%$ \\
\hline \multirow{6}{*}{$\begin{array}{l}\text { 14. A odontologia é a área } \\
\text { onde eu posso oferecer } \\
\text { minha melhor contribuição; }\end{array}$} & Discordo fortemente & 10 & $4,05 \%$ \\
\hline & Discordo & 33 & $13,36 \%$ \\
\hline & Neutro & 41 & $16,60 \%$ \\
\hline & Concordo & 110 & $44,53 \%$ \\
\hline & Concordo fortemente & 53 & $21,46 \%$ \\
\hline & Total & 247 & $100 \%$ \\
\hline
\end{tabular}




\begin{tabular}{l|c|c|c}
\hline 17. Em geral, estou & Discordo fortemente & 25 & $10,12 \%$ \\
extremamente satisfeito & Discordo & 63 & $25,51 \%$ \\
com minha carreira; & Neutro & 43 & $17,41 \%$ \\
& Concordo & 84 & $34,01 \%$ \\
& Concordo fortemente & 32 & $12,96 \%$ \\
\cline { 2 - 4 } & Total & 247 & $100 \%$ \\
\hline 20. Sinto-me limitado em & Discordo fortemente & 35 & $14,17 \%$ \\
minha posição/meu cargo & Discordo & 78 & $31,58 \%$ \\
atual. & Neutro & 49 & $19,84 \%$ \\
& Concordo & 67 & $27,13 \%$ \\
& Concordo fortemente & 18 & $7,29 \%$ \\
\cline { 2 - 4 } & Total & 247 & $100 \%$ \\
\hline
\end{tabular}


Cerca de $40 \%$ dos respondentes concordam que a renda obtida com a profissão possibilita o sustento da família, entretanto, essa mesma estimativa da porcentagem, acredita que, comparado a outros cirurgiões-dentistas, seus ganhos totais são muito menores do que se gostaria (Tabela 5.34).

Tabela 5.34 - Frequência de resposta para o questionário satisfação no trabalho (dimensão: renda)

\begin{tabular}{|c|c|c|c|}
\hline \multicolumn{2}{|c|}{ Renda } & \multirow{2}{*}{$\begin{array}{l}\text { Número } \\
\text { absoluto }\end{array}$} & \multirow{2}{*}{$\frac{\text { Porcentagem }}{10,53 \%}$} \\
\hline \multirow{6}{*}{$\begin{array}{l}\text { 02. Minha renda permite } \\
\text { que eu sustente minha } \\
\text { família muito bem; }\end{array}$} & Discordo fortemente & & \\
\hline & Discordo & 71 & $28,74 \%$ \\
\hline & Neutro & 49 & $19,84 \%$ \\
\hline & Concordo & 76 & $30,77 \%$ \\
\hline & Concordo fortemente & 25 & $10,12 \%$ \\
\hline & Total & 247 & $100 \%$ \\
\hline \multirow{6}{*}{$\begin{array}{l}\text { 10. Comparado a outros } \\
\text { cirurgiões-dentistas meus } \\
\text { ganhos totais são muito } \\
\text { menores do que eu } \\
\text { gostaria; }\end{array}$} & Discordo fortemente & 27 & $10,93 \%$ \\
\hline & Discordo & 67 & $27,13 \%$ \\
\hline & Neutro & 44 & $17,81 \%$ \\
\hline & Concordo & 74 & $29,96 \%$ \\
\hline & Concordo fortemente & 35 & $14,17 \%$ \\
\hline & Total & 247 & $100 \%$ \\
\hline \multirow{6}{*}{$\begin{array}{l}\text { 21. A renda que recebo de } \\
\text { minha prática é, na maior } \\
\text { parte das vezes, } \\
\text { satisfatória para minhas } \\
\text { necessidades; }\end{array}$} & Discordo fortemente & 22 & $8,91 \%$ \\
\hline & Discordo & 71 & $28,74 \%$ \\
\hline & Neutro & 38 & $15,38 \%$ \\
\hline & Concordo & 94 & $38,06 \%$ \\
\hline & Concordo fortemente & 22 & $8,91 \%$ \\
\hline & Total & 247 & $100 \%$ \\
\hline \multirow{6}{*}{$\begin{array}{l}\text { 23. Minha renda não é, } \\
\text { nem de perto, tão alta } \\
\text { quanto a de outros } \\
\text { cirurgiões-dentistas; }\end{array}$} & Discordo fortemente & 24 & $5,67 \%$ \\
\hline & Discordo & 55 & $22,27 \%$ \\
\hline & Neutro & 71 & $28,74 \%$ \\
\hline & Concordo & 83 & $33,60 \%$ \\
\hline & Concordo fortemente & 24 & $9,72 \%$ \\
\hline & Total & 247 & $100 \%$ \\
\hline \multirow{6}{*}{$\begin{array}{l}\text { 25. Minha renda pode ser } \\
\text { comparada } \\
\text { favoravelmente à de } \\
\text { outros cirurgiões-dentistas. }\end{array}$} & Discordo fortemente & 16 & $6,48 \%$ \\
\hline & Discordo & 48 & $19,43 \%$ \\
\hline & Neutro & 73 & $29,55 \%$ \\
\hline & Concordo & 101 & $40,89 \%$ \\
\hline & Concordo fortemente & 9 & $3,64 \%$ \\
\hline & Total & 247 & $100 \%$ \\
\hline
\end{tabular}


Quanto ao bloco tempo pessoal, quase $40 \%$ dos profissionais declaram que possuem tempo para lazer, também discordaram, quando questionados se o tempo disponível para suas vidas pessoais era suficiente (Tabela 5.35).

Tabela 5.35 - Frequência de resposta para o questionário satisfação no trabalho (bloco: tempo pessoal)

\begin{tabular}{l|c|c|c}
\hline \multicolumn{2}{c|}{ Tempo pessoal } & $\begin{array}{c}\text { Número } \\
\text { absoluto }\end{array}$ & Porcentagem \\
\hline 07. Tenho tempo suficiente & Discordo fortemente & 21 & $8,50 \%$ \\
disponível para minha vida & Discordo & 76 & $30,77 \%$ \\
pessoal; & Neutro & 45 & $18,22 \%$ \\
& Concordo & 81 & $32,79 \%$ \\
& Concordo fortemente & 24 & $9,72 \%$ \\
\cline { 2 - 4 } & Total & 247 & $100 \%$ \\
\hline 15. Tenho tempo suficiente & Discordo fortemente & 31 & $12,65 \%$ \\
& Discordo & 83 & $33,88 \%$ \\
& Neutro & 37 & $15,10 \%$ \\
& Concordo & 73 & $29,80 \%$ \\
\hline 29. Tenho pouquíssimo & Discordo fortemente & 37 & $14,98 \%$ \\
tempo disponível para & Discordo & 81 & $32,79 \%$ \\
atividades de lazer. & Neutro & 42 & $17,00 \%$ \\
\cline { 2 - 4 } & Concordo fortemente & 21 & $8,57 \%$ \\
\hline & Concordo & 24 & $24,70 \%$ \\
& Concordo fortemente & 26 & $10,57 \%$ \\
\hline & Total & 247 & $100 \%$ \\
\hline
\end{tabular}


Já em relação ao tempo profissional, a maioria dos profissionais acham que têm tempo para se manterem atualizados na profissão, cerca de $40 \%$ declararam ter tempo para contato com colegas e a maioria tem oportunidades muito limitadas para discutir casos difíceis com colegas (Tabela 5.36).

Tabela 5.36 - Frequência de resposta para o questionário satisfação no trabalho (bloco: tempo profissional)

\begin{tabular}{|c|c|c|c|}
\hline \multicolumn{2}{|c|}{ Tempo profissional } & \multirow{2}{*}{$\begin{array}{l}\begin{array}{l}\text { Número } \\
\text { absoluto }\end{array} \\
81\end{array}$} & \multirow{2}{*}{$\begin{array}{c}\text { Porcentagem } \\
32,79 \%\end{array}$} \\
\hline \multirow{6}{*}{$\begin{array}{l}01 . \text { Tenho pouquíssimo } \\
\text { tempo para me manter } \\
\text { atualizado a respeito dos } \\
\text { avanços na área de } \\
\text { odontologia; }\end{array}$} & Discordo fortemente & & \\
\hline & Discordo & 94 & $38,06 \%$ \\
\hline & Neutro & 38 & $15,38 \%$ \\
\hline & Concordo & 28 & $11,34 \%$ \\
\hline & Concordo fortemente & 06 & $2,43 \%$ \\
\hline & Total & 247 & $100 \%$ \\
\hline \multirow{6}{*}{$\begin{array}{l}\text { 4. Tenho tempo suficiente } \\
\text { para melhorar minhas } \\
\text { habilidades clínicas; }\end{array}$} & Discordo fortemente & 9 & $3,64 \%$ \\
\hline & Discordo & 39 & $15,79 \%$ \\
\hline & Neutro & 64 & $25,91 \%$ \\
\hline & Concordo & 102 & $41,30 \%$ \\
\hline & Concordo fortemente & 33 & $13,36 \%$ \\
\hline & Total & 247 & $100 \%$ \\
\hline \multirow{6}{*}{$\begin{array}{l}\text { 22. Tenho tempo suficiente } \\
\text { para contatos profissionais } \\
\text { com colegas; }\end{array}$} & Discordo fortemente & 11 & $4,45 \%$ \\
\hline & Discordo & 87 & $35,22 \%$ \\
\hline & Neutro & 63 & $25,51 \%$ \\
\hline & Concordo & 77 & $31,17 \%$ \\
\hline & Concordo fortemente & 09 & $3,64 \%$ \\
\hline & Total & 247 & $100 \%$ \\
\hline \multirow{6}{*}{$\begin{array}{l}\text { 26. Tenho oportunidades } \\
\text { muito limitadas para } \\
\text { discutir casos difíceis com } \\
\text { colegas. }\end{array}$} & Discordo fortemente & 46 & $18,62 \%$ \\
\hline & Discordo & 112 & $45,34 \%$ \\
\hline & Neutro & 26 & $10,53 \%$ \\
\hline & Concordo & 57 & $23,08 \%$ \\
\hline & Concordo fortemente & 6 & $2,43 \%$ \\
\hline & Total & 247 & $100 \%$ \\
\hline
\end{tabular}


Considerando o bloco equipe, a maioria dos profissionais discorda que a qualidade de pessoal auxiliar deixa a desejar e cerca de $40 \%$ concordam que o rendimento dos auxiliares é excelente (Tabela 5.37).

Tabela 5.37 - Frequência de resposta para o questionário satisfação no trabalho (bloco: equipe)

\begin{tabular}{l|c|c|c}
\hline \multicolumn{2}{c|}{ Equipe } & $\begin{array}{c}\text { Número } \\
\text { absoluto }\end{array}$ & Porcentagem \\
\hline 08. A qualidade de meu & Discordo fortemente & 35 & $14,17 \%$ \\
pessoal auxiliar deixa a & Discordo & 112 & $45,34 \%$ \\
desejar; & Neutro & 48 & $19,43 \%$ \\
& Concordo & 43 & $17,41 \%$ \\
& Concordo fortemente & 9 & $3,64 \%$ \\
\cline { 2 - 4 } & Total & 247 & $100 \%$ \\
\hline 18. O rendimento de & Discordo fortemente & 9 & $3,64 \%$ \\
excelente; & Discordo & 55 & $22,27 \%$ \\
& Neutro & 92 & $37,25 \%$ \\
& Concordo & 84 & $34,01 \%$ \\
& Concordo fortemente & 7 & $2,83 \%$ \\
\hline 19. A equipe da clínica & Total & 247 & $100 \%$ \\
\hline trabalha bem em & Discordo fortemente & 4 & $1,62 \%$ \\
conjunto. & Discordo & 22 & $8,91 \%$ \\
\cline { 2 - 4 } & Neutro & 73 & $29,55 \%$ \\
& Concordo & 128 & $51,82 \%$ \\
& Concordo fortemente & 20 & $8,10 \%$ \\
\hline & Total & 247 & $100 \%$ \\
\hline
\end{tabular}


No bloco paciente, é possível observar que apenas uma minoria acha que se relacionar com o paciente é frustrante e não gosta de interagir com os pacientes. A grande maioria declarou que gosta de ajudar os pacientes (Tabela 5.38).

Tabela 5.38 - Frequência de resposta para o questionário satisfação no trabalho (bloco: paciente)

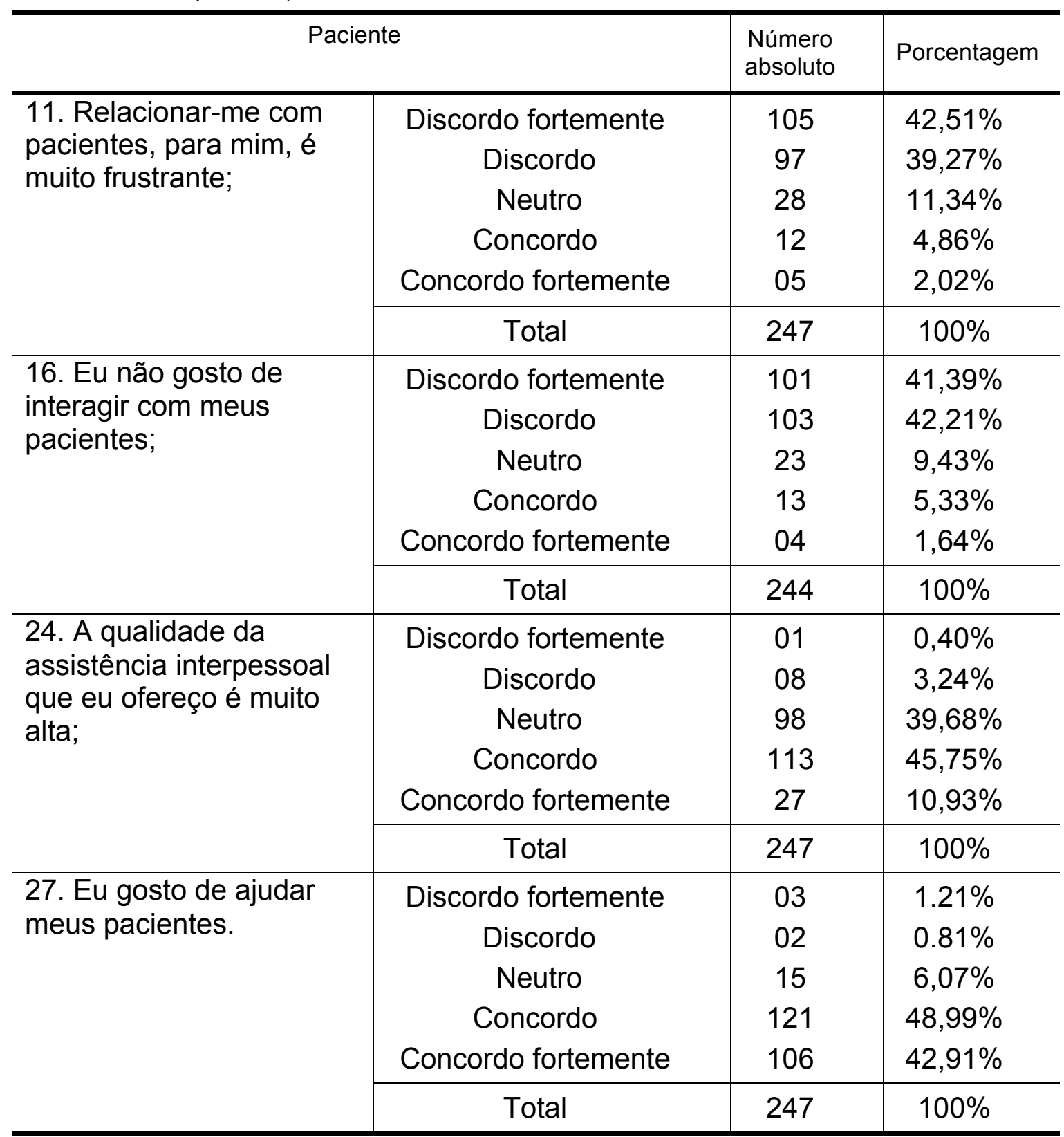


A grande maioria dos respondentes concordam que estão preparados tecnicamente para cuidar dos problemas de seus pacientes e possuem muita satisfação com a qualidade técnica de seu trabalho (Tabela 5.39).

Tabela 5.39 - Frequência de resposta para o questionário satisfação no trabalho (bloco: fornecimento de assistência)

\begin{tabular}{|c|c|c|c|}
\hline \multicolumn{2}{|c|}{ Fornecimento de assistência } & \multirow{2}{*}{$\begin{array}{c}\begin{array}{c}\text { Número } \\
\text { absoluto }\end{array} \\
02\end{array}$} & \multirow{2}{*}{$\begin{array}{c}\text { Porcentagem } \\
0,81 \%\end{array}$} \\
\hline \multirow{6}{*}{$\begin{array}{l}\text { 03. Eu estou tecnicamente } \\
\text { preparado para lidar com } \\
\text { os problemas } \\
\text { odontológicos de meus } \\
\text { pacientes; }\end{array}$} & Discordo fortemente & & \\
\hline & Discordo & 10 & $4,05 \%$ \\
\hline & Neutro & 19 & $7,69 \%$ \\
\hline & Concordo & 131 & $53,04 \%$ \\
\hline & Concordo fortemente & 85 & $34,41 \%$ \\
\hline & Total & 247 & $100 \%$ \\
\hline \multirow{6}{*}{$\begin{array}{l}\text { 13. Eu perco } \\
\text { oportunidades de fornecer } \\
\text { assistência/atendimento } \\
\text { de qualidade; }\end{array}$} & Discordo fortemente & 71 & $28,86 \%$ \\
\hline & Discordo & 100 & $40,65 \%$ \\
\hline & Neutro & 43 & $17,48 \%$ \\
\hline & Concordo & 30 & $12,20 \%$ \\
\hline & Concordo fortemente & 02 & $0,81 \%$ \\
\hline & Total & 247 & $100 \%$ \\
\hline \multirow{6}{*}{$\begin{array}{l}\text { 28. Eu tenho muita } \\
\text { satisfação com a } \\
\text { qualidade técnica de meu } \\
\text { trabalho. }\end{array}$} & Discordo fortemente & 03 & $1,21 \%$ \\
\hline & Discordo & 08 & $3,24 \%$ \\
\hline & Neutro & 27 & $10,93 \%$ \\
\hline & Concordo & 139 & $56,28 \%$ \\
\hline & Concordo fortemente & 70 & $28,34 \%$ \\
\hline & Total & 247 & $100 \%$ \\
\hline
\end{tabular}

\subsubsection{Média dos resultados do questionário DSS}

O nível de satisfação dos participantes foi de 3,43 ( $\mathrm{DP}=0,53)$, em uma escala de $1 \mathrm{a} 5$. Os valores para cada bloco podem ser analisados na tabela 5.40 , sendo que o bloco referente ao relacionamento com pacientes obteve a maior média e o bloco tempo pessoal a menor. 
Tabela 5.40 - Valores de Média e Desvio Padrão para cada bloco da escala DSS

\begin{tabular}{lccc}
\hline \multicolumn{1}{c}{ Blocos } & Média & $\begin{array}{c}\text { Desvio } \\
\text { Padrão }\end{array}$ & Mín/Máx \\
\hline Relacionamento com pacientes & 4,06 & 0.58 & $2,25 / 5,00$ \\
Fornecimento de assistência/atendimento & 4,02 & 0,64 & $1,00 / 5,00$ \\
Tempo profissional & 3,45 & 0,75 & $1,00 / 5,00$ \\
Equipe & 3,38 & 0,73 & $1,00 / 5,00$ \\
Satisfação geral com o trabalho/emprego & 3,26 & 0,91 & $1,00 / 5,00$ \\
Percepção de renda & 3,15 & 0.90 & $1,00 / 5,00$ \\
Tempo pessoal & 3,01 & 1,10 & $1,00 / 5,00$ \\
\hline Total & 3,43 & 0,53 & $1,93 / 4,86$ \\
\hline
\end{tabular}


A tabela 5.41 apresenta os itens para a formação do indicador de satisfação profissional do bloco satisfação geral com o emprego, aqui pode-se observar que a questão sobre a odontologia ser a área de oferecimento da melhor contribuição obteve a maior média, enquanto a pergunta sobre parecer mais satisfeito/a com o trabalho/emprego do que realmente está apresentou a menor média.

Tabela 5.41 - Distribuição dos cirurgiões-dentistas segundo satisfação no trabalho (bloco: satisfação geral)

\begin{tabular}{|c|c|c|c|}
\hline Satisfação geral com o trabalho/emprego & Média & $\begin{array}{l}\text { Desvio } \\
\text { Padrão }\end{array}$ & Mín/Máx \\
\hline $\begin{array}{l}\text { 05. A odontologia preenche minhas } \\
\text { atuais aspirações com a carreira; }\end{array}$ & 3,17 & 1,29 & $1,00 / 5,00$ \\
\hline $\begin{array}{l}\text { 06. Gostaria de deixar o meu } \\
\text { emprego/trabalho para fazer outra coisa; }\end{array}$ & 3,61 & 1,30 & $1,00 / 5,00$ \\
\hline $\begin{array}{l}\text { 09. Eu pareço mais satisfeito/a com meu } \\
\text { trabalho/emprego do que realmente } \\
\text { estou; }\end{array}$ & 2,99 & 1,11 & $1,00 / 5,00$ \\
\hline $\begin{array}{l}\text { 12. Sabendo o que eu sei hoje, eu teria } \\
\text { tomado a mesma decisão de fazer } \\
\text { odontologia novamente; }\end{array}$ & 3,11 & 1,36 & $1,00 / 5,00$ \\
\hline $\begin{array}{l}\text { 14. A odontologia é a área onde eu } \\
\text { posso oferecer minha melhor } \\
\text { contribuição; }\end{array}$ & 3,65 & 1,08 & $1,00 / 5,00$ \\
\hline $\begin{array}{l}\text { 17. Em geral, estou extremamente } \\
\text { satisfeito com minha carreira; }\end{array}$ & 3,14 & 1,22 & $1,00 / 5,00$ \\
\hline $\begin{array}{l}\text { 20. Sinto-me limitado em minha } \\
\text { posição/meu cargo atual. }\end{array}$ & 3,18 & 1,19 & $1,00 / 5,00$ \\
\hline
\end{tabular}


A tabela 5.42, referente ao bloco percepção de renda, mostra a maior média para a afirmação que diz que sua renda não é, nem de perto, tão alta em relação a dos seus colegas de profissão.

Tabela 5.42 - Distribuição dos cirurgiões-dentistas segundo satisfação no trabalho (bloco: renda)

\begin{tabular}{lccc}
\hline \multicolumn{1}{c}{ Percepção de renda } & Média & $\begin{array}{l}\text { Desvio } \\
\text { Padrão }\end{array}$ & Mín/Máx \\
\hline $\begin{array}{l}\text { 02. Minha renda permite que eu sustente } \\
\text { minha família muito bem; }\end{array}$ & 3,01 & 1,19 & $1,00 / 5,00$ \\
$\begin{array}{l}\text { 10. Comparado a outros cirurgiões- } \\
\text { dentistas meus ganhos totais são muito } \\
\text { menores do que eu gostaria; }\end{array}$ & 2,90 & 1,25 & $1,00 / 5,00$ \\
$\begin{array}{l}\text { 21. A renda que recebo de minha prática } \\
\text { é, na maior parte das vezes, satisfatória } \\
\text { para minhas necessidades; }\end{array}$ & 3,09 & 1,17 & $1,00 / 5,00$ \\
$\begin{array}{l}\text { 23. Minha renda não é, nem de perto, tão } \\
\text { alta quanto a de outros cirurgiões- } \\
\text { dentistas; }\end{array}$ & 3,19 & 1,06 & $1,00 / 5,00$ \\
$\begin{array}{l}\text { 25. Minha renda pode ser comparada } \\
\text { favoravelmente à de outros cirurgiões- } \\
\text { dentistas. }\end{array}$ & 3,15 & 0,99 & $1,00 / 5,00$ \\
\hline
\end{tabular}

Em relação ao tempo pessoal, a tabela 5.43 mostra que os cirurgiõesdentistas participantes desta pesquisa acreditam que possuem pouco tempo para o lazer, questão que obteve menor média do bloco.

Tabela 5.43 - Distribuição dos cirurgiões-dentistas segundo satisfação no trabalho (bloco: tempo pessoal)

\begin{tabular}{lccc}
\multicolumn{1}{c}{ Tempo pessoal } & Média & $\begin{array}{l}\text { Desvio } \\
\text { Padrão }\end{array}$ & Mín/Máx \\
\hline $\begin{array}{l}\text { 07. Tenho tempo suficiente disponível } \\
\text { para minha vida pessoal; }\end{array}$ & 3,04 & 1,16 & $1,00 / 5,00$ \\
$\begin{array}{l}\text { 15. Tenho tempo suficiente para } \\
\text { atividades de lazer; }\end{array}$ & 2,87 & 1,21 & $1,00 / 5,00$ \\
$\begin{array}{l}\text { 29. Tempo pouquíssimo tempo } \\
\text { disponível para atividades de lazer. }\end{array}$ & 3,17 & 1,25 & $1,00 / 5,00$ \\
\hline
\end{tabular}


A análise da tabela nos permite perceber que os cirurgiões-dentistas da amostra não concordam que possuem tempo suficiente para contato com os colegas, entretanto, acham que possuem tempo para se manterem atualizados (Tabela 5.44).

Tabela 5.44 - Distribuição dos cirurgiões-dentistas segundo satisfação no trabalho (bloco: tempo profissional)

\begin{tabular}{lccc}
\hline \multicolumn{1}{c}{ Tempo profissional } & Média & $\begin{array}{l}\text { Desvio } \\
\text { Padrão }\end{array}$ & Mín/Máx \\
\hline $\begin{array}{l}\text { 01. Tenho pouquíssimo tempo para me } \\
\text { manter atualizado a respeito dos avanços } \\
\text { na área de odontologia; }\end{array}$ & 3,87 & 1,06 & $1,00 / 5,00$ \\
$\begin{array}{l}\text { 04. Tenho tempo suficiente para } \\
\text { melhorar minhas habilidades clínicas; }\end{array}$ & 3,44 & 1,02 & $1,00 / 5,00$ \\
$\begin{array}{l}\text { 22. Tenho tempo suficiente para contatos } \\
\text { profissionais com colegas; }\end{array}$ & 2,94 & 0,99 & $1,00 / 5,00$ \\
$\begin{array}{l}\text { 26. Tenho oportunidades muito limitadas } \\
\text { para discutir casos difíceis com colegas. }\end{array}$ & 3,54 & 1,11 & $1,00 / 5,00$ \\
\hline
\end{tabular}

Em relação à equipe, os cirurgiões-dentistas concordam que a equipe da clínica trabalha bem em conjunto, questão com maior média do bloco (Tabela $5.45)$.

Tabela 5.45 - Distribuição dos cirurgiões-dentistas segundo satisfação no trabalho (bloco: equipe)

\begin{tabular}{lccc}
\hline \multicolumn{1}{c}{ Equipe } & Média & $\begin{array}{c}\text { Desvio } \\
\text { Padrão }\end{array}$ & Mín/Máx \\
\hline $\begin{array}{l}\text { 08. A qualidade de meu pessoal auxiliar } \\
\text { deixa a desejar; }\end{array}$ & 3,48 & 1,05 & $1,00 / 5,00$ \\
$\begin{array}{l}\text { 18. O rendimento de meus auxiliares é } \\
\text { excelente; }\end{array}$ & 3,10 & 0,90 & $1,00 / 5,00$ \\
$\begin{array}{l}\text { 19. A equipe da clínica trabalha bem em } \\
\text { conjunto. }\end{array}$ & 3,55 & 0,82 & $1,00 / 5,00$ \\
\hline
\end{tabular}


Para o bloco paciente, a questão com maior média diz respeito ao gosto de ajudar os pacientes e a menor média em relação à qualidade da assistência interpessoal (Tabela 5.46).

Tabela 5.46 - Distribuição dos cirurgiões-dentistas segundo satisfação no trabalho (bloco: paciente)

\begin{tabular}{lccc}
\hline \multicolumn{1}{c}{ Paciente } & Média & $\begin{array}{c}\text { Desvio } \\
\text { Padrão }\end{array}$ & Mín/Máx \\
\hline $\begin{array}{l}\text { 11. Relacionar-me com pacientes, para } \\
\text { mim, é muito frustrante; }\end{array}$ & 4,15 & 0,94 & $1,00 / 5,00$ \\
$\begin{array}{l}\text { 16. Eu não gosto de interagir com meus } \\
\text { pacientes; }\end{array}$ & 4,16 & 0,91 & $1,00 / 5,00$ \\
$\begin{array}{l}\text { 24. A qualidade da assistência } \\
\text { interpessoal que eu ofereço é muito alta; }\end{array}$ & 3,63 & 0,73 & $1,00 / 5,00$ \\
\begin{tabular}{l} 
27. Eu gosto de ajudar meus pacientes. \\
\hline
\end{tabular} & 4,31 & 0,73 & $1,00 / 5,00$ \\
\hline
\end{tabular}

A análise do bloco fornecimento de assistência mostra a maior média em relação à opinião do profissional com relação a sua preparação técnica para lidar com os problemas odontológicos dos pacientes (Tabela 5.47).

Tabela 5.47 - Distribuição dos cirurgiões-dentistas segundo satisfação no trabalho (fornecimento de assistência)

\begin{tabular}{lccc}
\hline \multicolumn{1}{c}{ Fornecimento de assistência } & Média & $\begin{array}{l}\text { Desvio } \\
\text { Padrão }\end{array}$ & Mín/Máx \\
\hline $\begin{array}{l}\text { 03. Eu estou tecnicamente preparado para } \\
\text { lidar com os problemas odontológicos de } \\
\text { meus pacientes; }\end{array}$ & 4,16 & 0,79 & $1,00 / 5,00$ \\
$\begin{array}{l}\text { 13. Eu perco oportunidades de fornecer } \\
\text { assistência/atendimento de qualidade; }\end{array}$ & 3,84 & 1,00 & $1,00 / 5,00$ \\
$\begin{array}{l}\text { 28. Eu tenho muita satisfação com a } \\
\text { qualidade técnica de meu trabalho. }\end{array}$ & 4,07 & 0,79 & $1,00 / 5,00$ \\
\hline
\end{tabular}




\subsection{RELAÇÃO ENTRE A ESCALA DMS-BR E DSS}

A relação encontrada entre as duas escalas - DSS e DMS-BR - foi de 0.65 $(p<0,05)$. Assim, considerando-se que a relação fortíssima varia de 9 a 1 , a forte de 6 a 9, a média de 3 a 6 e a fraca de 1 a 3, a relação entre as duas escalas pode ser considerada forte.

A relação entre as dimensões da escala DMS-BR e os blocos da escala de satisfação está mostrada na Tabela 5.48. É possível observar que a satisfação profissional foi mais impactada positivamente pela dimensão carreira, seguido pela produtividade, financeiro e paciente, conforme tabela abaixo (Tabela 5.48).

Tabela 5.48 - Relação entre as dimensões da escala DMS-BR e os blocos da escala DSS.

\begin{tabular}{lc}
\hline $\begin{array}{l}\text { Dimensão da escala conhecimento e } \\
\text { aplicação de ferramentas de marketing } \\
\text { (DMS-BR) }\end{array}$ & $\begin{array}{c}\text { Força da relação com a } \\
\text { escala de satisfação } \\
\text { (DSS) }\end{array}$ \\
\hline Carreira & 0,661 \\
Produtividade & 0,541 \\
Financeiro & 0,523 \\
Paciente & 0,509 \\
Qualidade & 0,444 \\
Equipe & 0,432 \\
Concorrência & 0,431 \\
Ponto & 0,415 \\
Marketing & 0,405 \\
\hline
\end{tabular}


A relação entre os blocos da escala DSS e as dimensões da escala DMS$B R$ pode ser visualizada na tabela 5.49. O bloco referente à equipe foi o que mais impactou na relação entre a satisfação profissional e a escala DMS-BR.

Tabela 5.49 - Relação entre os blocos da escala DSS e as dimensões da escala DMS-BR.

\begin{tabular}{lc}
\hline $\begin{array}{l}\text { Blocos da escala de satisfação profissional } \\
\text { (DSS) }\end{array}$ & $\begin{array}{c}\text { Força da relação com a } \\
\text { escala DMS-BR }\end{array}$ \\
\hline Equipe & 0,520 \\
Satisfação geral com o trabalho/emprego & 0,491 \\
Percepção de renda & 0,479 \\
Fornecimento de assistência/atendimento & 0,477 \\
Tempo profissional & 0,419 \\
Relacionamento com pacientes & 0,285 \\
Tempo pessoal & 0,270 \\
\hline
\end{tabular}




\section{DISCUSSÃO}

A discussão será apresentada em tópicos para melhor entendimento do leitor.

\subsection{SELEÇÃO DA AMOSTRA}

A amostra foi composta por cirurgiões-dentistas de todo o Brasil, que foram convidados a participarem da pesquisa por meios digitais. Em comparação aos meios físicos caracterizados por envio dos questionários via correio, os meios digitais trazem uma série de benefícios e, por isso, estão ganhando força nos últimos anos devido à praticidade, à conclusão do processo em menor tempo e aos menores custos envolvidos, além disso, podem alcançar bases populacionais de maior abrangência geográfica e sua qualidade de resposta é tão satisfatória quanto a dos meios físicos (Schaefer; Dillman, 1998; Kaplowitz et al., 2004; Sheehan, 2001).

Entretanto, esse método pode trazer algumas limitações por pré-selecionar pessoas com acesso à internet e que poderiam ter mais disponibilidade de informações sobre o tema central da pesquisa: gestão. Entretanto, por se tratar de uma tendência mundial o uso da internet para pesquisas acadêmicas, essa pode ser considerada uma limitação relativa.

\subsection{CARACTERIZAÇÃO DA AMOSTRA}

Conforme dados levantados por Morita et al. (2010), São Paulo detém o maior numero de inscritos do Conselho Federal de Odontologia, concordando com os dados da presente pesquisa, na qual foi encontrado que $81,78 \%$ dos 
respondentes eram da região Sudeste e a grande maioria destes do estado de São Paulo. Os mesmo autores constataram que $72 \%$ das Universidades de Odontologia existentes no pais são particulares, fato que concorda com a característica da amostra do presente estudo, no qual pode-se observar que mais da metade dos participantes realizaram a graduação neste tipo de instituição de ensino. Outros autores também acharam dados semelhantes quanto à formação dos cirurgiões-dentistas (Oliveira, 2005; Michel-Crosato, 2008).

Quanto aos cursos de pós-graduação, cerca de $60 \%$ da amostra do presente estudo respondeu que possui pelo menos uma especialização, o que concorda com diversos levantamentos de outros autores. Dos 53.679 especialistas registrados no CFO em 2008, cerca de $56 \%$ encontravam-se no Sudeste. Em São Paulo, por sua vez, concentram-se $50 \%$ dos especialista da região Sudeste, fato esse que concorda com a alta concentração de especialistas da amostra (Morita et al., 2010).

Bastos et al. (2003) também constataram, em seu estudo sobre a análise do perfil de egressos da Faculdade de Odontologia de Bauru, entre os anos de 1996 e 2000, que 66,3\% da amostra já haviam concluído ou estavam fazendo algum curso de pós-graduação. Isso vai ao encontro dos achados no estudo de Mialhe et al. (2008), que estudou o perfil profissional de cirurgiões-dentistas formados na Universidade de Campinas, em sua maioria entre os anos de $1998 \mathrm{e}$ 2003 , e observou que $62,80 \%$ dos respondentes possuíam ou estavam cursando especialização.

Marsiglia (1998) e Marcelino (2000) encontraram em seus respectivos estudos a tendência à especialização dos cirurgiões-dentistas. Ponte (2011), em seu levantamento sobre a satisfação profissional de cirurgiões-dentistas que atuavam em empresa privada da cidade de São Paulo, também constatou que mais da metade da amostra possui curso de especialização.

Ainda, sobre a área da especialização, conforme encontrado em levantamento de dados do CFO em 2008, as áreas com maior número de inscritos no Conselho são: Ortodontia, Endodontia e Odontopediatria (Morita et al., 2010). Já no presente estudo, as maiores frequências na amostra foram as áreas de Ortodontia, seguido de Implantodontia e Prótese. As especialidades clínicas, em especial Ortodontia e Cirurgia-oral, podem ter maior prestígio na 
comunidade odontológica devido ao maior retorno financeiro que proporcionam, por isso possuem bastante procura pelos dentistas (Tanalp et al., 2012).

A atuação em consultório próprio ou de terceiros é a grande realidade da odontologia brasileira (Morita et al., 2010) e esse achado no estudo está em consonância à diversos outros trabalhos. Bastos et al. (2003) observaram que o perfil predominante de inserção dos alunos egressos da Faculdade de Odontologia de Bauru no mercado de trabalho se dá por meio do atendimento em consultório particular próprio $(38,8 \%)$ ou em porcentagem $(25,5 \%)$.

Mialhe et al. (2008), ao verificarem a inserção, no mercado de trabalho, de alunos da Faculdade de Odontologia da Unicamp de 1998 a 2006, constataram que $65,7 \%$ da amostra se declarou como sendo autônomo. Michel-Crosato (2008) avaliou uma amostra de cirurgiões-dentistas do setor público de São Paulo e descobriu que quase $63 \%$ dos profissionais também acumulavam funções no setor privado. Oliveira (2005) verificou em sua amostra de alunos de pósgraduação da UNIP e FUNDECTO que $63,5 \%$ dos profissionais trabalham exclusivamente ou predominantemente em consultório próprio.

Embora o setor público tenha, ao longo do tempo, aumentado a oferta de cargos para os profissionais da Odontologia, principalmente com o aumento do número de Equipes de Saúde Bucal inseridas no contexto do Programa de Saúde da Família (Morita et al., 2010), além do olhar dos currículos dos cursos de graduação para se atender a essa nova perspectiva (Morita; Kriger, 2006; Zilbovicius, 2007), observou-se nesta pesquisa que apenas $17 \%$ dos profissionais trabalham no setor público. Entretanto, Rezende et al. (2007) mostraram que essa pode ser uma realidade a ser modificada, uma vez que, enquanto os alunos do primeiro ano da Faculdade de Odontologia de Taubaté esperam trabalhar em consultório próprio, os alunos do quarto ano desejam ter emprego público. Pinheiro et al. (2011) relataram uma taxa de $46,5 \%$ dos cirurgiões-dentistas acessados em sua pesquisa com vínculo público. 


\subsection{DMS-BR: GESTÃO COM FOCO NA ODONTOLOGIA - CURRÍCULO DE FACULDADES, CONHECIMENTO POR PARTE DOS PROFISSIONAIS E DESAFIOS DO MERCADO DE TRABALHO}

Os resultados do presente estudo mostraram que os cirurgiões-dentistas atingiram um nível de 3,77 (DV 0,45) em uma escala de 1 a 5 . Esse escore pode ser considerado regular com relação ao conhecimento e prática de gestão, sendo que as dimensões que mais influenciaram no resultado foram: ponto, qualidade e equipe.

Quanto à esfera financeira, $64,8 \%$ dos profissionais afirmaram que a formação de preço cobrado no consultório levou em consideração os gastos fixos e variáveis, o que concorda com a resposta de outra pergunta complementar do instrumento em relação ao assunto, em que $60 \%$ da amostra acreditam que o conhecimento acerca dos gastos fixos e variáveis do consultório são ótimos ou bons. Entretanto, $61,1 \%$ consideram entre regular e insatisfatório o planejamento financeiro para uma futura aposentadoria.

Os achados para a dimensão financeiro também concordam com as conclusões gerais do estudo de Oliveira (2005), que demostrou que a maioria dos profissionais entrevistados atribuem máxima importância ao controle de contas a pagar e a receber, a maioria se preocupa com o resultado financeiro de sua atividade, além de reconhecer que os conteúdos de finanças são relevantes para o pleno desempenho da função dentro da Odontologia.

Entretanto, Oliveira e Oliveira Junior (1999) alertam para o fato de que que, após uma análise mais profunda dos resultados obtidos em seu estudo, foi constatado que, embora os cirurgiões-dentistas tivessem uma noção dos custos para formação dos honorários, esta era superficial, podendo, por exemplo, negligenciar o valor de depreciação dos bens materiais duráveis do consultório. Ribas et al. (2010) também concluíram que os dentistas possuem um controle financeiro deficiente.

A questão da produtividade está intimamente ligada ao sucesso do consultório como empresa, uma vez que os cirurgiões-dentistas recebem sua remuneração sobre o atendimento do paciente. Esta dimensão, que obteve média geral de $3,73(\mathrm{DP}=0,64)$, mostrou-se com bons resultados, sendo que quase $70 \%$ 
da amostra consideraram como boa ou ótima a quantidade de pacientes que recebem mensalmente por meio do boca a boca ou indicação de colegas. Esse dado concorda com os resultados obtidos na pesquisa de Arcier et al. (2007) cuja demonstração constata que grande parte dos cirurgiões-dentistas de sua amostra recebiam pacientes por meio do boca a boca.

Nakama et al. (2004), entretanto, sugerem que os cirurgiões-dentistas mudem o comportamento relativo à primeira consulta a partir da implementação de ações para conquistar o paciente, tais como abordar as titulações e a qualificação profissional, as medidas de biossegurança, a promoção do contato pós-consulta, como telefone ou cartas, o agendamento da segunda consulta para a apresentação do plano de tratamento o mais breve possível, além da adoção de contratos para estabelecer as diretrizes da prestação de serviços.

Os resultados obtidos por Garcia et al. (2005) revelam que alguns recursos que poderiam ajudar na explicação do tratamento para o paciente, aumentando o poder de convencimento, estão sendo subutilizados, como vídeos, computador, slide, sendo que $68,9 \%$ dos cirurgiões-dentistas afirmaram que usam somente a comunicação visual.

Ainda nesta dimensão, mais de $80 \%$ da amostra afirmou como sendo ótima ou boa a produtividade e a eficiência no trabalho. Esse fato pode ser explicado também por ferramentas de gestão empregadas na agenda do dentista, assim como observaram Kühnen e Ribeiro (2012), cuja constatação é de que 94,4\% utilizam estratégias para diminuir o número de faltas.

Quanto ao ponto, que está englobado nos P's do marketing, a maioria dos cirurgiões-dentistas respondeu entre ótimo e bom para a facilidade de acesso $(91,5 \%)$, fato este que está de acordo com o que os pacientes acreditam ser um dos atributos importantes para escolha de um consultório (Klann et al., (2011). Entretanto, foi observado por Kühnen e Ribeiro (2012), em sua pesquisa, que apenas $12,2 \%$ das 138 clínicas estudadas, haviam tido seu local de instalação escolhido após uma pesquisa de mercado, mostrando a pouca importância dada à escolha do ponto. A decoração e o conforto de acordo com o público-alvo $(79,8 \%)$ e estado de conservação e decoração da sala de atendimento (90,3\%) também se mostraram, como a maioria das respostas, entre ótimo e bom. A dimensão ponto obteve melhor média do instrumento para essa amostra, com $3,23(\mathrm{DP}=0,54)$. 
Esses aspectos apontados pela presente pesquisa são importantes do ponto de vista do marketing, pois traduzem a tangibilidade da qualidade dos serviços, isto é: o paciente não é tecnicamente capaz de avaliar um serviço odontológico, assim, com o objetivo de minimizar os riscos do consumo desses serviços, buscam pistas tangíveis, que eles podem facilmente avaliar para atribuírem qualidade ao serviço (Clow et al., 1994; Lovelock; Writz, 2008). Esses atributos passam pela decoração do consultório, assim como cordialidade da equipe, paramentação do profissional, entre outros aspectos. Não se encontra na literatura, entretanto, o comportamento dos cirurgiões-dentistas acerca dessas questões.

Com relação a dimensão qualidade, que obteve uma média de 3,10 $(\mathrm{DP}=0,47)$, os cirurgiões-dentistas demostraram ter ótima situação em relação à documentação legal do consultório $(59,11 \%)$. A organização do consultório foi considerada entre ótima e boa pela maioria da amostra, assim como controle de estoque. Em relação ao desempenho dos fornecedores, como laboratórios de prótese e dentais, apenas 8,91\% acham ótimo e 30\% da amostra os classificam como regular, fraco ou insatisfatório. Quase $96 \%$ da amostra afirmou que sua proteção individual, usando os EPIs, é ótima ou boa. Esse é um dos aspectos que impactam o julgamento de um paciente em relação a qualidade de um serviço (Karydis et al., 2001; Garbin et al., 2008a).

Referente à qualidade dos prontuários, cerca de $70 \%$ afirmaram que a qualidade e a organização dos prontuários é ótima ou boa. Carneiro-Neto et al. (2008) relatam que $80,22 \%$ dos cirurgiões-dentistas faziam anamnese em todos os pacientes, $53,84 \%$ realizam o registro das condições pré-tratamento e $54,94 \%$ arquivam cópias de receitas assinadas pelo paciente, demostrando bom nível de qualidade dos prontuários. Brito (2005) observou que 52,3\% dos 181 cirurgiõesdentistas entrevistados na cidade de Natal, Rio Grande do Norte conferem importância clínica à documentação e todos os profissionais acessados na pesquisa utilizam os documentos de acordo com as exigências de todas as atividades clínicas. Porém, apenas $30 \%$ arquivam atestados, receitas e encaminhamento. Entretanto, tanto Carneiro-Neto et al. (2008) quanto Brito (2005) relataram que a amostra desconhecia as obrigações legais referentes à documentação odontológica. Assim, por ser um questionário de autopercepção, 
pode ser esse o motivo de um número elevado de cirurgiões-dentistas que consideram seus prontuários com alta qualidade.

A dimensão carreira se mostrou com média de 3,87 ( $D P=0,64)$. Frente às respostas obtidas, é possível observar que os profissionais estão aplicando os conceitos de ergonomia na organização do consultório, item sobre o qual 40,5\% dos profissionais relataram estar em ótima situação. Este fato é bastante animador, pois a aplicação de princípios de ergonomia no dia a dia evitam prejuízos para a saúde, como dor e maiores morbidades que podem diminuir a produtividade e a qualidade de vida do trabalhador (Campos; Garcia, 2005; Graça et al., 2006). A formação técnico-científica também se mostrou com bom rendimento, uma vez que mais de $75 \%$ da amostra marcou como boa ou ótima a quantidade e qualidade dos cursos, analisando os últimos quatro anos

Os profissionais da odontologia se mostram bastante dedicados a essa atualização profissional e reconhecem que a formação é essencial para o pleno desenvolvimento profissional (Bastos et al., 2003; Brustolin et al., 2006; Klann et al., 2011), fato esse que converge com o que o paciente busca como atributo do dentista. Newsome e Wright (1999) afirmaram em sua revisão que as competências técnicas estão como os itens mais impactantes na satisfação do paciente; Klann et al. (2011) concluem que $48,7 \%$ dos pacientes consideram que o profissional deve estar atualizado tecnologicamente, e Garbin et al. (2008a) que $23,3 \%$ dos pacientes esperam um bom trabalho técnico do profissional.

A dimensão referente aos pacientes demostrou ter um ótima consistência interna, com alpha de Cronbach de 0,81. A questão com menor média, de 2,86 $(\mathrm{DP}=1,08)$, foi referente à comunicação com o paciente por meio de ligações para clientes antigos, envio de e-mails ou mala direta, entre outras, mostrando que os cirurgiões-dentistas não possuem uma estratégia de relacionamento com os pacientes fora do momento da consulta.

Entretanto, mais de $80 \%$ da amostra considera como ótima e boa a atenção que dedicam aos pacientes antes, durante e após as consultas. A relação profissional da área de saúde/paciente já é relatada como sendo um importante fator de satisfação do paciente desde o início do século XX, conforme o relato da historiadora Nancy Tomes (Tomes, 2001). Essa expectativa dos pacientes podem ainda ser encontrada em estudos mais atuais, como o de Holt e McHugh (1997), em que $90 \%$ dos participantes afirmaram que a atenção e o cuidado oferecidos 
pelos profissionais eram muito importantes para a sua satisfação. Os dados encontrados nessa pesquisa, ainda vão ao encontro dos achados de Klann et al. (2011), em cujo estudo constataram que quase todos os profissionais entrevistados concordam que tratar o paciente com respeito é indispensável, assim como a habilidade de ouvi-los.

A partir dos resultados encontrados na pesquisa, pode-se afirmar que o horário das consultas são cumpridos por $58,70 \%$ dos profissionais. Esses dados concordam com os achados de Klann et al. (2011), que concluíram que os 55,7\% cirurgiões-dentistas consideram o cumprimento do horário como um item importante para a satisfação do paciente. Garbin et al. (2008a), relatam ainda que um dos fatores que mais desconfortam os pacientes quando procuram atendimento odontológico é o descumprimento de horário, seguido pelo barulho do motor.

A dimensão equipe pontuou 4,02 (DP=0,56) de média, situando-se entre as 3 mais altas, com uma correlação com o escore final do instrumento de $70 \%$. A maioria dos profissionais classificam a comunicação, o trabalho desenvolvido, a atenção dada aos comentários realizados pela equipe como bom ou ótimo, demostrando uma boa relação profissional/equipe. A habilidade de comunicação com os membros da equipe deve ser construída na graduação, conforme o item IV do artigo $4^{\circ}$ das Diretrizes Curriculares Nacionais:

\footnotetext{
Liderança: no trabalho em equipe multiprofissional, os profissionais de saúde deverão estar aptos a assumirem posições de liderança, sempre tendo em vista o bem estar da comunidade. A liderança envolve compromisso, responsabilidade, empatia, habilidade para tomada de decisões, comunicação e gerenciamento de forma efetiva e eficaz.
}

Esses dados estão convergentes com os achados de Arcier et al. (2007), que verificaram que $87,7 \%$ de sua amostra de cirurgiões-dentistas de São Paulo ofereceram informações sobre relacionamento profissional com os pacientes aos membros da equipe, justificando assim a qualidade percebida em relação ao desempenho deles. Porém, em seu levantamento Kühnen e Ribeiro (2012) constataram que apenas $38,9 \%$ dos responsáveis técnicos disseram ter dado treinamento para a equipe.

Quanto a dimensão concorrência, cerca de $72 \%$ da amostra considerou como ótima ou boa a sua situação em relação à vantagem competitiva em frente 
aos demais profissionais, $51 \%$ declaram que seus conhecimentos sobre seus concorrentes é de regular a insatisfatório e foi observado que $75 \%$ possuem bom nível de conhecimento sobre seus próprios pontos fortes e fracos. Segundo Ribas et al. (2010), a vantagem competitiva na área de gestão passa por dois pontos, sendo um deles a qualidade do exercício profissional, e outro a gestão, que engloba o relacionamento com o cliente, a infraestrutura do consultório, a formação de preços, entre outros aspectos. Assim, conhecer o desempenho dos concorrentes com relação ao leque de serviços ofertados, os avanços tecnológicos adotados no consultório, assim como seus pontos fracos e fortes são itens importantes a serem englobados em um análise de mercado e podem ajudar o profissional a direcionar suas ações rumo a uma vantagem competitiva de sucesso.

A amostra do estudo não mostrou, contudo, um adequado desempenho para a dimensão marketing, possuindo a menor média entre as dimensões estudadas - 3,10 ( $\mathrm{DP}=0,71)$. Quando questionada sobre as estratégias para atrair novos pacientes, apenas $2,83 \%$ da amostra atribuiu como ótimas suas ações. Cerca de $70 \%$ dos participantes marcaram as alternativas de regular a insatisfatório para esse item. Entretanto, 80\% diz que seu nível de conhecimento quanto ao público-alvo é bom ou ótimo, o que é essencial para o planejamento de ações estratégicas para o consultório.

Para a divulgação dos serviços por meios impressos e digitais, 44,5\% da amostra assinalou como sendo fraca e insatisfatória sua situação nessa área. Entretanto, dados obtidos por Klann et al. (2011) demostram que os pacientes acham a distribuição de folhetos mais importante que os cirurgiões-dentistas, sendo essa uma ação de marketing em que os cirurgiões-dentistas deveriam investir. Quanto à presença digital para fins comerciais, sejam eles divulgar os serviços ou construir relacionamentos com os pacientes, a odontologia, ao que parece, ainda se mostra em um estágio bastante inicial. Rajan et al. (2011) verificaram que a grande maioria dos profissionais dos Emirados Árabes Unidos estudados não achavam que as redes sociais eram mídias adequadas para promoverem seus serviços e a maioria usa esses sites com propósitos pessoais.

Os profissionais dos EUA estão um pouco mais abertos para essa realidade, sendo que $51 \%$ alegaram que usam o Facebook profissionalmente, entretanto, sentem dificuldade de saber como se comportar nesta mídia e de 
mensurar o sucesso de suas ações (Henry et al., 2012), o que pode, em parte, a resistência dos profissionais em usufruir dos benefícios dessa mídia. Outra possível explicação que corrobora esse fato é que alguns profissionais ainda possuem certa atitude contrária à divulgação dos serviços, como anúncios, achando que podem prejudicar a imagem dos profissionais, o que não é verificado quando acessada a opinião dos pacientes (Clow et al., 2007; Moser, 2008).

Em relação à parte administrativa da profissão, 48,5\% classificam a sua atuação como sendo de regular a insatisfatória, o que concorda com outros autores que mostram que os cirurgiões-dentistas não gostam dessa esfera da profissão (Wells; Winter, 1999; Luzzi et al., 2005; Mialhe et al., 2008; Bates et al., 2013) e, por isso, podem negligenciar o conhecimento e a prática dessas atividades. Ainda, cerca de $60 \%$ dos participantes concordam que os seus conhecimentos sobre a área de marketing e administração são fracos ou insuficientes.

Enquanto o mercado de trabalho em odontologia oferece uma série de desafios aos profissionais, como o número excessivo de cirurgiões-dentistas no mercado, a grande quantidade de faculdades por todo país que continuam a formar profissionais ano após ano, a má distribuição de profissionais no território, resultando em grande concentração de mão de obra nas grandes capitais e principalmente na região Sudeste do país (Bastos et al., 2003; Michel-Crosato, 2008; Morita et al., 2010), além de um mercado de trabalho dinâmico, as faculdades continuam com o ensino voltado para o aprender técnico e científico, ignorando o fato de que a maioria dos profissionais formados exercerá sua atividade em um consultório, seja ele próprio ou de terceiros (Bastos et al., 2003; Crosato, 2003; Oliveira, 2005; Mialhe et al., 2008; Michel-Crosato, 2008; Morita et al., 2010). Atuando no âmbito particular, como empreendedores, onde os recursos deverão ser transformados em serviços com o propósito de ofertar saúde bucal à população, os conhecimentos de gestão poderiam facilitar o dia a dia do profissional, assim como dar embasamento para melhores tomadas de decisão.

Entretanto, pode-se observar também uma visão conturbada da profissão por parte dos alunos, o que também é um desafio que deverá ser enfrentado pelas Universidades. Os alunos de odontologia geralmente buscam o curso por vocação ou afinidade, como demostrado por Bastos et al. (2003), Silva et al., (2011), Mialhe et al. (2008), Cavalcanti et al. (2010) e Ponte (2012), ou ainda por 
seu aspecto liberal (Marcelino, 2000; Slavutzky et al., 2002), cuja característica valorizada é fazer o próprio horário ou ainda não ter chefe.

Além disso, grande parte dos estudos mostram que os alunos possuem a expectativa de atuar durante sua vida profissional em consultório próprio (Slavutzky et al., 2002; Silva et al., 2011; Ponte, 2012). Não há relatos, entretanto, de motivações por razões de empreendedorismo, abrir ou gerir uma empresa ou ser chefe. Porém, fazendo uma análise mais profunda dos dados, é possível observar que há uma visão deturpada da profissão por parte dos ingressantes das faculdades, uma vez que não são raros os relatos de pesquisas que trazem o descontentamento dos profissionais acerca das obrigações administrativas da profissão (Wells; Winter, 1999; Luzzi et al., 2005; Mialhe et al., 2008).

Além disso, a importância, as vantagens e as deficiências do ensino de habilidades de gestão e administrativas são mostradas por Bastos et al. (2003), Mialhe et al. (2008), Pourabbas et al. (2013) e Gonzalez et al. (2013). Por sua vez, Zuchini et al. (2012) observaram que $77 \%$ dos cirurgiões-dentistas de sua amostra já tinham ouvido falar de marketing porém este era um conhecimento incipiente. Ou seja, embora tenham uma noção de fermentas administrativas, esse conhecimento é desestruturado e sem embasamento científico.

É fato também que os profissionais já inseridos no mercado acreditam que cursos na área de gestão, administração, finanças e afins podem contribuir para o seu sucesso profissional (Bastos et al., 2003; Oliveira, 2005; Ponte, 2009). Como já observado por vários outros autores, o despertar das habilidades gerenciais e administrativas deve ser iniciado durante a graduação e não quando o profissional já se encontra no mercado de trabalho.

A escala desenvolvida se mostrou bastante abrangente em relação aos temas que aparecem na vida dos profissionais da odontologia, na qualidade de gestores. As questões foram construídas visando contemplar os quesitos avaliados em processos de acreditação, como sua versão se mostrou acessível e apropriada para os propósitos do estudo. Os testes estatísticos confirmam a boa consistência interna do questionário, sendo seu alpha de Conbrach de 0.925 . 


\subsection{SATISFAÇÃO PROFISSIONAL}

A revisão da literatura mostra que o trabalho assume uma importante parte da vida de um indivíduo, trazendo-Ihe tanto a questão da sobrevivência, ou seja, abastecer suas necessidades fisiológicas, sociais e econômicas, como a aceitação de um propósito para definir o significado para sua existência, no sentido de contribuir de alguma forma com outras pessoas. Por isso, o trabalho pode interferir tanto na saúde mental quanto física do indivíduo (Peterson; Dunnagan, 1998; Faragher et al., 2005).

Devido às múltiplas facetas que o sentimento em relação à profissão pode englobar, é incoerente pensar em uma dicotomia para o estado de satisfação de um profissional, quando se pensa em direcionamentos futuros sobre a Odontologia. Assim, torna-se mais adequado utilizar escalas multifacetadas validadas para a mensuração desse aspecto ao invés da simples pergunta "você está satisfeito com a profissão", o que não nos permitiria discutir sobre os aspectos específicos de satisfação e insatisfação.

Com relação a utilização da escala DSS e suas modificações são bastante usadas na literatura, embora haja divergência entre os autores quanto às dimensões que impactam a satisfação profissional e não seja possível encontrar um padrão ouro para mensurar esse sentimento em relação à profissional (Shugars et al.,1991; Wells; Winter, 1999; Van Saane et al., 2003; Jeong et al., 2006).

A partir dos resultados obtidos pela escala de satisfação profissional, a média geral da amostra foi de $3,43(\mathrm{DP}=0,53)$, de uma escala de 1 a 5 . Pode-se concluir que os profissionais que participaram do estudo se mostram em um nível neutro em relação à profissão. $O$ bloco que demostra ser o maior indicador de satisfação foi referente ao relacionamento com os pacientes e o menor indicador foi acerca do tempo pessoal, que apresentou menor média entre os respondentes.

Roth (2003), usou a mesma escala utilizada no presente trabalho - DSS com modificações para a Ortodontia. Seus resultados mostram que a amostra estudada está satisfeita com a profissão, a média foi de 4,02 (DP=0,63), sendo 1 completamente insatisfeito e 5 completamente satisfeito. Além disso, encontrou 
que $85,3 \%$ afirmaram estarem satisfeitos ou muito satisfeitos com a carreira e $87,3 \%$ escolheriam novamente a especialidade de ortodontia.

Acordando com os dados desse estudo, Jeong et al. (2006) estudaram uma amostra de cirurgiões-dentistas coreanos que obtiveram uma média de 3,02, classificada como neutra, sendo que o tempo pessoal foi o bloco que se apresentou com menor média, e relacionamento com os pacientes com a maior. Outros autores também mostram que o fornecimento de assistência é um fator que impacta positivamente o sentimento em relação à profissão (Wells; Winter, 1999; Kelsey et al., 2009) enquanto o tempo pessoal impacta negativamente (Logan et al., 1997; Ponte, 2011).

Para uma amostra de dentistas da prefeitura de São Paulo no ano de 2007, Michel-Crosato (2008) também utilizou o DSS. Sua amostra obteve uma média de $2,84(\mathrm{DP}=0,29)$, demostrando que os profissionais dessa amostra também se mostram neutros em relação à profissão. Uma possível explicação é que os profissionais se sentem limitados quanto ao fornecimento de assistência ideal para o paciente nesse ambiente de trabalho, por isso esse bloco obteve a menor média para essa amostra.

Ponte (2009) estudou cirurgiões-dentistas empregados em uma empresa privada inserida no conceito social e observou que a amostra se demostrou também neutra em relação à profissão, com maior media para o bloco relacionamento com o paciente, e menor média para tempo pessoal, dados esses que concordam com os achados deste trabalho.

Os dados encontrados por Fahim (2013), que acessou a satisfação no trabalho de cirurgiões-dentistas da Jordânia por meio do DSS e observou que os profissionais se sentem neutros em relação à profissão, também estão de acordo com o presente estudo.

Vários trabalhos que usaram outros tipos de questionários-escalas para mensurar a satisfação profissional constataram que os profissionais expressavam um sentimento favorável em relação à profissão (Moimaz et al., 2003; Luzzi et al., 2005; Michel-Crosato et al., 2006; Pinheiro et al., 2011; Ordell et al., 2013).

Entretanto, é possível que os respondentes realmente insatisfeitos com a carreira não participem da amostra desses tipos de estudos, por não atuarem mais na área da Odontologia, tendo ido buscar outras formas de obtenção de satisfação profissional em atividades econômicas distintas da Odontologia. 


\subsection{SATISFAÇÃO PROFISSIONAL RELACIONADA COM O USO DA GESTÃO NA ODONTOLOGIA}

Analisando algumas questões que compõem a escala DSS, como a comparação da renda em relação aos outros profissionais, a questão do tempo disponível para as atividades pessoais, qualidade dos serviços do pessoa auxiliar, a qualidade técnica oferecida aos pacientes pode incitar uma relação entre satisfação profissional e gestão. Dessa forma, uma boa formação de preços aliada à uma boa estratégia de marketing pode alcançar resultados financeiros de alto rendimento, impactando esse aspecto da satisfação profissional, do mesmo modo que uma gestão eficaz de agenda e organização de processos podem gerar maior produtividade, reduzindo as horas de trabalho necessárias para um mesmo rendimento, e sobrando tempo para outras atividades, como, por exemplo, lazer.

Assim, os indícios empíricos que levaram a realização do presente estudo podem ser observados na forte relação entre as escalas DMS-BR e DSS, mostrando que há uma ligação entre ambas dimensões da vida profissional do indivíduo: parte administrativa da profissão, representada no presente estudo pela gestão, e satisfação profissional. Pode-se entender então que uma gestão eficaz, principalmente, mas não somente, nos âmbitos da carreira, produtividade, financeiro e paciente, podem impactar positivamente a satisfação profissional.

Embora o presente trabalho tenha um foco no âmbito privado, uma boa gestão, no setor público, geralmente exercida por profissionais designados para exercerem exclusivamente essa atividade, pode impactar positivamente a satisfação dos profissionais e da equipe de trabalho, pois permitem alcançar processos mais eficazes e coerentes, além de um ambiente de trabalho mais agradável, motivador e propenso a trazer qualidade de vida ao trabalhador.

Com menor força de relação, é possível observar que a satisfação profissional também impactou o resultado obtido do DMS-BR, sendo que o bloco equipe foi o que mais se destacou nessa relação. Este bloco, no instrumento DSS, possui três perguntas, das quais duas possuem um caráter bastante gerencial, com relação ao rendimento e à qualidade de trabalho da equipe. Assim, esperava-se que esse dimensão pudesse ter uma forte relação com a gestão. 


\subsection{LIMITAÇÕES E FUTUROS ESTUDOS}

O trabalho possui algumas limitações:

- A gestão aplicada às empresas possui uma essência complexa envolvendo áreas de matemática, recursos humanos, planejamento, fluxo de caixa, etc., assim o questionário foi construído sobre alguns desses aspectos, julgados pela pesquisadora como os mais importantes, entretanto, pode-se não ter englobado todos os pontos referentes ao tema.

- Os participantes, em sua maioria eram da região Sudeste do país, que concentra a maior parte dos profissionais de odontologia, assim presume-se que essa população aplique mais ferramentas de gestão/marketing devido a alta concorrência de mercado na região.

- A amostra foi composta, em sua maioria por profissionais, com mais de 15 anos de formado, assim esse aspecto pode ter influenciado no resultado de satisfação, uma vez que Nicolielo e Bastos (2002) relataram que os profissionais com mais tempo de formados possuíam mais satisfação profissional do que os recém-formados.

Sugere-se que estudos futuros sejam realizados em outros ambientes de trabalhos empregadoras do cirurgião-dentista, como empresas e o setor público, para a verificar se uma boa gestão também pode influenciar a satisfação profissional dessas amostras. 


\section{CONCLUSÕES}

A partir deste estudo, é possível concluir que o questionário DM-BR possui boa confiança interna e externa, tendo apresentado bons indicadores de consistência e, portanto, está validado. Observou-se que os indicadores críticos essenciais à gestão de consultórios odontológicos encontrados nesta pesquisa foram: ponto, qualidade e equipe.

No âmbito da satisfação profissional, a amostra se mostrou neutra.

Referente à relação entre os instrumentos, pode-se concluir que os constructos da escala DMS-BR mostraram-se capazes de impactar a satisfação profissional da amostra estudada, sendo que as dimensões que mais influenciaram a satisfação profissional foram: produtividade, financeiro e paciente. Assim, conclui-se que a gestão no âmbito da odontologia pode impactar a satisfação profissional e vice-versa. 


\section{REFERÊNCIAS 1}

Allen BH, Wright RA, Raho LE. Physicians and advertising. J Health Care Mark. 1985;5(4):39.

Anderson R. Patient expectations of emergency dental services: a qualitative interview study. Br Dent J. 2004;197(6):331-4.

Arcier N, Silva M, Arcieri R, Garbin C. A importância do marketing odontológico para enfrentar um mercado competitivo. Rev Odontol Araçatuba. 2007;28(3):24-32.

Bastos JRM, Aquilante AG, de ALMEIDA BS, Lauris JRP, Bijella VT. Análise do perfil profissional de cirurgiões-dentistas graduados na Faculdade de Odontologia de Bauru-USP entre os anos de 1996 e 2000. J Appl Oral Sci. 2003;11(4):283-9.

Bates LF, Buehler AM, Boynton JR, Majewski RF, Inglehart MR. Pediatric Dentists' Job Satisfaction: Results of a National Survey. Pediatr Dent. 2013;35(4):343-50.

Bengmark D, Nilner M, Rohlin M. Dentists reflect on their problem-based education and profissional satisfaction. Eur J Dent Educ. 2012;16(1):e137-e45.

Brito EWG. A documentação odontológica sob a ótica dos cirurgiões-dentistas de Natal-RN. 2005.[Dissertação]. Rio Grande do Norte: Universidade Federal do Rio Grande do Norte; 2005.

Brown SW, Fisk RP, Bitner MJ. The development and emergence of services marketing thought. Int J Serv Ind Manag. 1994;5(1):21-48.

Brustolin J, Brustolin J, Toassi RFC, Kuhnen M. Perfil do acadêmico de Odontologia da Universidade do Planalto Catarinense-Lages-SC, Brasil. Rev ABENO. 2006;6(1):70-6.

Bussom RS, Darling JR. Medical fee and service advertising: a response from physicians. Medic Care. 1978:110-21.

\footnotetext{
${ }^{1}$ De acordo com estilo Vancouver.
} 
Campos JADB, Garcia PPNS. Ergonomia em odontologia. Rev Paul Odontol. 2005;27(2):36-8.

Carneiro Neto H, Cunha FL, Melani RFH. Avaliação dos mestrandos em ortodontia: Utilização dos documentos que compõe o prontuário odontológico. Rev Odontol Acad Tiradentes Odontol. 2008;10:537-67.

Cavalcanti AL, Lima WGd, Marques JLdS, Alves HFC, Granville-Garcia AF. Motivos de ingresso e de evasão dos acadêmicos de Odontologia de uma instituição pública. Rev Odontol UNESP. 2010;39(2):95-9.

Clow KE, Fischer AK, O'Bryan D. Patient expectations of dental services. Image affects expectations, and expectations affect perceived service quality. J Health Care Mark. 1994;15(3):23-31.

Clow KE, Stevens RE, McConkey CW, Loudon DL. Attitudes of Dentists and Dental Patients Toward Advertising. Health Mark Q. 2007;24(1-2):23-34.

CNE DR. CES 3/2002. Diário Oficial da União. Diretrizes Curriculares Nacionais do Curso de Graduação em Odontologia. Brasília. Brasília, 4 de março de 2002. Seção 1 p. $10 . \quad$ [cited 20 maio 2014]. Disponível em: http://portal.mec.gov.br/cne/arquivos/pdf/CES032002.pdf

Collet EL, Brenner MLS, Campos L, Bueno RN, Bottan ER. A opinião de um grupo de adultos sobre as qualidades essenciais a um cirurgião-dentista. Salusvita Bauru. 2011;30(3):11.

Corah NL, O'Shea RM, Pace LF, Seyrek SK. Development of a patient measure of satisfaction with the dentist: The dental visit satisfaction scale. J Behav Med. 1984;7(4):367-73.

Crosato EM, Calvielli ITP, Biazevic MGH, Crosato E. Perfil socioeconômico da força de trabalho representada pelos egressos da FOUSP (1990-1998); Workforce profile of the graduates from the School of Dentistry, University of São Paulo, between 1990-1998. RPG Rev Pos-Grad. 2003;10(3):217-26.

Dable RA, Prasanth M, Singh SB, Nazirkar GS. Is advertising ethical for dentists? An insight into the Indian scenario. Drug Healthc Patient Saf. 2011;3:93. 
Davies AR, Ware Jr JE. Measuring patient satisfaction with dental care. Soc Sci Med Part A: Med Psychol Med Soc. 1981;15(6):751-60.

Dias EP. Conceitos de gestão e administração: uma revisão crítica. REA-Rev Eletr Adm. Facet. [citado 20 maio 2014]. Disponível em: http://periodicos.unifacef.com.br/index.php/rea/article/download/160/16.

Drucker PF. Introdução à administração. São Paulo: Pioneira; 1998.

Engels Y, Dautzenberg M, Campbell S, Broge B, Boffin N, Marshall M, et al. Testing a European set of indicators for the evaluation of the management of primary care practices. Fam Pract. 2006;23(1):137-47.

Fahim AE. Predictors of job satisfaction among practicing dentists at hospitals in Suez Canal Area, Egypt. Int J Occup Med Environ Health. 2013;26(1):49-57.

Faragher EB, Cass M, Cooper CL. The relationship between job satisfaction and health: a meta-analysis. Occup Environ Med. 2005;62(2):105-12.

Folland ST. Advertising by physicians: Behavior and attitudes. Med Care. 1987;25(4):311-26.

Furnham A, Swami V. Patient preferences for dentists. Psychol Health Med. 2009;14(2):143-9.

Garbin AJI, Garbin CAS, Tiano AVP, Carvalho ML, da Graça Fagundes AC. Marketing em Odontologia: a percepção do cliente em relação ao serviço odontológico de clínica privada. Rev Odontol UNESP. 2008a;37(2):197-202.

Garbin CAS, Garbin AJI, Dossi AP, Macedo L, Macedo V. O tratamento odontológico: informações transmitidas aos pacientes e motivos de insatisfação. Rev Odontol UNESP. 2008b;37(2):177-81.

Garcia PPNS, Serra MdC, Dotta EAV. Primeira consulta: estratégias adotadas por cirurgiões-dentistas para a conquista de pacientes. Rev Odontol UNESP. 2005;34(1):43-8. 
Garcia SJ, Caetano JC. O código de ética odontológica e suas infrações: um estudo sobre os processos ético-profissionais dos cirurgiões dentistas do estado de Santa Catarina. Odontol Clín-Cient. 2008;7(4):307-13.

Gilmour J, Stewardson D, Shugars D, Burke F. An assessment of career satisfaction among a group of general dental practitioners in Staffordshire. $\mathrm{Br}$ Dent $\mathrm{J}$. 2005;198(11):701-4.

Goetz K, Campbell S, Broge B, Brodowski M, Wensing M, Szecsenyi J. Effectiveness of a quality management program in dental care practices. BMC Oral Health. 2014;14(1):41.

Goetz K, Campbell S, Broge B, Dörfer C, Brodowski M, Szecsenyi J. The impact of intrinsic and extrinsic factors on the job satisfaction of dentists. Commun Dent Oral Epidemiol. 2012;40(5):474-80.

Gomes D, Gonçalves ASR, Pereira LdS, Tavares RdS, Pires DEPd, Ramos FRS. Satisfação e sofrimento no trabalho do cirurgião-dentista. RFO UPF. 2010;15(2):10410.

Gonzalez MAG, Abu Kasim NH, Naimie Z. Soft skills and dental education. European J Dent Educ. 2013;17(2):73-82.

Gorter RC, Te Brake HJ, Hoogstraten J, Eijkman MA. Positive engagement and job resources in dental practice. Commun Dent Oral Epidemiol. 2008;36(1):47-54.

Graça CC, Araújo TM, Silva CEP. Desordens musculoesqueléticas em cirurgiõesdentistas. Sitientibus. 2006;34:71-86.

Henry RK, Molnar A, Henry JC. A survey of US dental practices' use of social media. J Contemp Dent Pract. 2012;13(2):137-41.

Herzberg F, Mausner B, Snyderman B. The motivation to work. NewYork, NY: John Wiley and Sons;1959. p141.

Hite RE, Bellizzi JA, Andrus DM. Consumer versus dentist attitudes toward dental services advertising. J Health Care Mark. 1988;8(1):95-105. 
Holt V, McHugh K. Factors influencing patient loyalty to dentist and dental practice. Br Dent J. 1997;183(10):365-70.

ludícibus S, Marion JC, Pereira E. Dicionário de termos de contabilidade. São Paulo: Atlas; 2001.

Jeong SH, Chung JK, Choi YH, Sohn W, Song KB. Factors related to job satisfaction among South Korean dentists. Commun Dent Oral Epidemiol. 2006;34(6):460-6.

Kalleberg AL. Work values and job rewards: A theory of job satisfaction. Am Sociol Rev. 1977:124-43.

Kaplowitz MD, Hadlock TD, Levine R. A comparison of web and mail survey response rates. Public Opin Q. 2004;68(1):94-101.

Karydis A, Komboli-Kodovazeniti M, Hatzigeorgiou D, Panis V. Expectations and perceptions of Greek patients regarding the quality of dental health care. International J Qual Health Care. 2001;13(5):409-16.

Keith RJ. The marketing revolution. J Mark. 1960:35-8.

Kotliarenko A, Michel-Crosato E, Biazevic MGH, Crosato E, da Silva PR. Distúrbios osteomusculares e fatores associados em cirurgiões dentistas do meio oeste do estado de Santa Catarina. Rev Odonto Ciênc. 2009;24(2).

Kelsey WP, Kimmes NS, Williams DE, Ogunleye AO, Ault JT, Barkmeier WW. Gender-based differences in satisfaction with academic preparation and practice experiences. J Dent Educ. 2009;73(4):464-70.

Klann MBP, Moraes MCB, Sarubbi FM. A percepção da qualidade de serviços odontológicos segundo cirurgiões-dentistas e pacientes de clínicas odontológicas de Florianópolis. $35^{\circ}$ Encontro ANPAD; 04-07 set 2011; Rio de Janeiro, BR. Rio de Janeiro: [s.n.]; 2011 [citado 21 maio 2014]. Disponível em http://www.simpoi.fgvsp.br/arquivo/2011/artigos/E2011_T00043_PCN12325.pdf.

Kotler P. Administração de marketing: análise, planejamento, implementação e controle. São Paulo: Atlas; 1994. 
Kotler P. Marketing para o século XXI: como criar, conquistar e dominar mercados. São Paulo: Futura; 2000.

Kühnen $\mathrm{CH}$, Ribeiro DM. A utilização das ferramentas de marketing pelos cirurgiõesdentistas; The use of marketing tools by dentists. Rev ABO Nac. 2012;20(6):363-8.

Lim J-S, Zallocco R. Consumer attitudes toward healthcare marketing practices: A comparison of hospitals vs. physicians. J Hosp Mark. 1998;12(1):91-108.

Locke EA. What is job satisfaction? Organ Behav Hum Perform. 1969;4(4):309-36.

Logan HL, Muller PJ, Berst MR, Yeaney DW. Contributors to dentists' job satisfaction and quality of life. J Am Coll Dent. 1997;64(4):39-43. Epub 1997/01/01.

Lovelock $\mathrm{CH}$, Wirtz J. Marketing de serviços: pessoas, tecnologia e resultados. São Paulo: Pearson Prentice Hall; 2008.

Luzzi L, Spencer AJ, Jones K, Teusner D. Job satisfaction of registered dental practitioners. Aust Dent J. 2005;50(3):179-85.

Marcelino G. Avaliação do perfil profissional e percepção social de cirurgiõesdentistas do município de Araçatuba-SP frente aos avanços ocorridos na odontologia às vésperas do século XXI [dissertação]. Araçatuba: Universidade Estadual Paulista, Faculdade de Odontologia de Araçatuba; 2000.

Marsiglia RMG. Perspectivas para o ensino das ciências sociais na graduação odontológica. In: Botazzo, C; Freitas, SFT. Ciências sociais e saúde bucal; questões e perscpectivas. São Paulo: UNESP;1998. p.176-96.

Martins ALG, Costa MA, dos Reis MVG, Ladeira LLC, Costa EL, Costa JF. Avaliação dos aspectos éticos da publicidade e propaganda odontológica divulgadas por profissionais em São Luís-MA. Rev Pesq Saúde. 2012;12(2):23-6.

Martins AMEBL, Barretos SM. Vacinação contra a hepatite B entre cirurgiões dentistas. Rev Saúde Pública. 2003;37(3):333-8.

Mialhe FL, Furuse R, Gonçalo CS. Perfil profissional de uma amostra de egressos da Faculdade de Odontologia de Piracicaba; Profissional profile of sample of graduates from Piracicaba Dental School. UFES Rev Odontol. 2008;10(2):31-6. 
Michel-Crosato E. Perfil da força de trabalho representada pelo Cirurgião-Dentista: análise epidemiológica dos profissionais que exerciam suas atividades na Prefeitura Municipal de São Paulo, 2007 [tese livre docência]. São Paulo: Universidade de São Paulo: Faculdade de Odontologia da USP; 2008.

Michel-Crosato E, Kotiliarenko A, Biazevic M. Prevalência de distúrbios osteomusculares em cirurgiões dentistas. Odontol Soc. 2006;8(1):89.

Moimaz SAS, Saliba NAS, Blanco MRB. A força do trabalho feminino na Odontologia, em Araçatuba-SP. J Appl Oral Sci. 2003;11(4):301-5.

Morita M, Kriger L. A relação ensino e serviços de Odontologia. Educação Odontológica São Paulo: Artes Médicas; 2006. p. 129-39.

Morita MC, Haddad AE, Araújo ME. Perfil atual e tendências do cirurgião-dentista brasileiro. Perfil atual e tendências do cirurgião-dentista brasileiro. Maringá: Dental Press; 2010.

Moser HR. How consumers view dental advertising: An empirical analysis. J Med Mark: Dev Diagn Pharm Mark. 2008;8(3):229-40.

Nakama R, Gandini Jr. LG, Chiavini PCR, Sakima MT. Conquistar clientes na primeira consulta: uma abordagem prática para clínica particular de Ortodontia e Ortopedia. Rev Clin Ortod Dental Press. 2004;3(1):76-82.

Newsome P, Wright GH. Patient Management: A review of patient satisfaction: 1. Concepts of satisfaction. Br Dent J. 1999;186(4):161-5.

Nicolielo J, Bastos JRdM. Satisfação profissional do cirurgião dentista conforme tempo de formado; Profissional satisfaction among dentists according to the year of graduation. Rev Fac Odontol Bauru. 2002;10(2):69-74.

O'steen V. Bates v. State Bar of Arizona: The Personal Account of a Party and the Consumer Benefits of Lawyer Advertising. Ariz St LJ. 2005;37:245.

Oliveira CML, Bezerra ESM, Lobato IH, Nobre RM, Machado SM, Barroso RF. Processos movidos contra cirurgiões-dentistas no Conselho Regional de Odontologia-seção Pará nos últimos sete anos. Saúde Ética Justiça. 2010;15(2). 
Oliveira FT, Sales Peres A, Sales Peres S, Yarid SD, Silva R. Ética odontológica: conhecimento de acadêmicos e cirurgiões-dentistas sobre os aspectos éticos da profissão. Rev Odontol UNESP. 2008;37(1):33-9.

Oliveira LA. Uso de contabilidade e finanças pelos cirurgiões-dentistas na gestão da atividade profissional-um estudo exploratório [dissertação]. São Paulo: Centro Universitário Álvares Penteado; 2005.

Oliveira RN, Oliveira Jr O. Honorários profissionais: sua importância no contexto do consultório odontológico. Odontol Soc. 1999;1(1/2):51-4.

Ordell S, Söderfeldt B, Hjalmers K, Berthelsen H, Bergström K. Organization and overall job satisfaction among publicly employed, salaried dentists in Sweden and Denmark. Acta Odontol Scand. 2013;71(6):1443-52.

Oweis Y, Hattar S, Eid RA, Sabra A. Dentistry a second time? Eur J Dent Educ. 2012;16(1):e10-e8.

Paim AP, de Camargo AC, da Silva ACM, Nóbrega FM, Cardoso MG. Marketing em odontologia. Rev Biociênc. 2008;10(4):223-9.

Pena RBJ, Júnior JHdSC, Araújo RJG, de Mello Santos LS, Fernandes MM, Prado $\mathrm{FB}$, et al. Processos éticos do Conselho Regional de Odontologia do Estado do Pará no período de 2007 a 2010. Saúde Ética Justiça. 2013;18(1):116-23.

Peterson M, Dunnagan T. Analysis of a worksite health promotion program's impact on job satisfaction. J Occup Environ Med. 1998;40(11):973-9.

Pickett GM, Grove SJ, Ratcliff R. Using promotion to increase dental practices. J Health Care Mark. 1992;12(2):22-36.

Pinheiro VC, Menezes LMBd, Aguiar ASWd, Moura WVBd, Almeida MELd, Pinheiro FMdC. Inserção dos egressos do curso de odontologia no mercado de trabalho. RGO. 2011;59(2):277-83.

Ponte TM. Perfil psicológico e interesses profissionais de estudantes de odontologia [tese]. São Paulo: Universidade de São Paulo, Faculdade de Odontologia; 2012. 
Ponte TM, Junqueira SR, Biazevic MGH, Frias AC, Araújo MEd, Michel-Crosato E. Satisfação profissional: perfil dos cirurgiões-dentistas que exercem suas atividades em empresa do setor privado-São Paulo, 2008. RPG Rev Pós-Grad. 2011;18(1):139.

Ponte TM, Zaitter WM, Biazevic MGH, Crosato E, Michel-Crosato E. Prática odontológica: perfil dos cirurgiões-dentistas que exercem suas atividades em empresa do setor privado-São Paulo, 2008. RSBO (Impr). 2009;6(3):265-71.

Pourabbas R. Competency Assessment of the Last Year Students of Tabriz Dentistry School in the Major Skills Needed for a New Dentist. J Med Educ. 2013;13(3):95100.

Puriene A, Petrauskiene J, Janulyte V, Balciuniene I. Factors related to job satisfaction among Lithuanian dentists. Stomatol Baltic Dent Maxillofac J. 2007;9:109-13.

Rajan AV, George S, Kirsal Y, editors. Modern dental practice for the dentists in the UAE using social networking tools. Current Trends in Information Technology (CTIT), 2011 International Conference and Workshop on; 2011: 26-27 Oct. 2011.

Rankin J, Harris M. Patients' preferences for dentists' behaviors. J Am Dent Assoc. 1985;110(3):323-7.

Rezende FP, Nakanishi FC, Machado ACP, de Souza Quirino MR, Anbinder AL. Perfil, motivações e expectativas dos graduandos e graduados em Odontologia. Rev Odontol Univ Cidade São Paulo. 2007;19(2):165-72.

Ribas MA, Siqueira ES, Binotto E. O desafio da gestão para profissionais da odontologia. $30^{\circ}$ Encontro Nacional de Engenharia de Produção; $12-15$ out 2010; São Carlos, BR. São Carlos:[s.n.]; 2010 [citado 21 maio 2014]. Disponível em: http://www.abepro.org.br/biblioteca/enegep2010_TN_STO_130_833_15943.pdf.

Richardson WC. Management Education for health services. Int J Health Serv. 1976;6(1):25-34.

Roth SF, Heo G, Varnhagen C, Glover KE, Major PW. Job satisfaction among Canadian orthodontists. American journal of orthodontics and dentofacial orthopedics. 2003;123(6):695-700. 
Rovida TAS, Viveiros GM, Queiroz APDdG, Marquesi C, Garbin CAS. Cartão de visitas - Uma estratégia de marketing profissional na prática odontológica. Ver Odontol Araçatuba. 2012;33(1):18-21.

Sassi C, Francesquini Júnior L, Daruge Júnior E, Fernandes MM, Picapedra A, de Bragança DPP, et al. Placas odontológicas: aspectos legais e orientações práticas. Rev Fac Odontol Lins. 2013;23(2):25-34.

Schaefer DR, Dillman DA. Development of a standard e-mail methodology: Results of an experiment. Public Opin Q. 1998:378-97.

Schouten BC, Eijkman MA, Hoogstraten J. Dentists' and patients' communicative behaviour and their satisfaction with the dental encounter. Commun Dent Health. 2003;20(1):11-5.

Serra MdC, Garcia PPNS, Dotta EAV, Gonçalves PE. Ferramentas de marketing empregadas por cirurgiões dentistas. RGO. 2005;53(2):155-8.

Sheehan, KB. (2001), E-mail Survey Response Rates: A Review. Journal of Computer-Mediated Communication, 6:0.doi:10.1111/j.1083-6101.2001.tb00117.x

Shostack GL. Breaking free from product marketing. J Mark. 1977:73-80.

Shugars DA, Hays RD, DiMatteo MR, Cretin S. Development of an instrument to measure job satisfaction among dentists. Med Care. 1991:728-44.

Shugerman R, Linzer M, Nelson K, Douglas J, Williams R, Konrad R, et al. Pediatric Generalists and Subspecialists: Determinants of Career Satisfaction. Pediatrics. 2001;108(3):e40.

Silva AC, Franco MM, Costa EL, Assunção HRM, Costa JF. Perfil do acadêmico de odontologia de uma universidade pública/Profile of dentistry students of a public university. Rev Pesq Saúde. 2011;12(1):22-26.

Slavutzky SM, Abbeg C, Gross RF, Rosa MAC. Mercado de trabalho: perfil do acadêmico de odontologia da Universidade Federal do Rio Grande do Sul. Rev Fac Odontol Porto Alegre. 2002;43(2):3-6.

Sur H, Hayran O, Mumcu G, Soylemez D, Atli H, Yildirim C. Factors Affecting Dental Job Satisfaction A Cross-Sectional Survey in Turkey. Eval Health Prof. 2004;27(2):152-64. 
Tanalp J, Ilguy D, Dikbas I, Oktay I. Demographic profile and future expectations of students enrolled in a Turkish private dental school. J Dent Educ. 2012;76(6):800-9. Tomes N. Merchants of health: medicine and consumer culture in the United States, 1900-1940. J Am Histy. 2001;88(2):519-47.

Usher W. Types of social media (Web 2.0) used by Australian allied health profissionals to deliver early twenty-first-century practice promotion and health care. Soc Work Health Care. 2011;50(4):305-29.

Van Saane N, Sluiter J, Verbeek J, Frings-Dresen M. Reliability and validity of instruments measuring job satisfaction-a systematic review. Occup Med. 2003;53(3):191-200.

Vargo SL, Lusch RF. Evolving to a new dominant logic for marketing. J Mark. 2004;68(1):1-17.

Wells A, Winter P. Influence of practice and personal characteristics on dental job satisfaction. J Dent Educ. 1999;63(11):805-12.

Wheeler CK, Said H, Prucz R, Rodrich RJ, Mathes DW. Social Media in Plastic Surgery Practices Emerging Trends in North America. Aesthet Surg J. 2011;31(4):435-41.

Williams ES, Konrad TR, Linzer M, McMurray J, Pathman DE, Gerrity M, et al. Refining the measurement of physician job satisfaction: results from the Physician Worklife Survey. Med Care. 1999:1140-54.

Yavas U, Riecken G. Attitudes of US doctors and dentists towards advertising: A comparative study. Int J Advert. 2001;20(3):341-60.

Zilbovicius C. Implantação das diretrizes curriculares para cursos de graduação em odontologia no Brasil: contradições e perspectivas [tese]. São Paulo: Universidade de São Paulo, Faculdade de Odontologia; 2007.

Zuchini ARB, Lolli MCGS, Lolli LF, Lolli HA. Perfil profissional do cirurgião-dentista em associação ao conhecimento e utilização de marketing. Arq Odontol. 2012;48(01):19-25. 
APÊNCIDE A - Dental Management Survey - Brasil

\begin{tabular}{|c|c|c|c|c|c|}
\hline Questões & $\begin{array}{l}\text { Ótimo } \\
\text { (a) }\end{array}$ & $\begin{array}{c}\text { Bom } \\
\text { (a) }\end{array}$ & Regular & Fraco & Insatisfatório \\
\hline \multicolumn{6}{|l|}{$\begin{array}{l}\text { 1. Como eu classifico a facilidade de } \\
\text { acesso da clínica ou consultório que } \\
\text { trabalho: }\end{array}$} \\
\hline \multicolumn{6}{|l|}{$\begin{array}{l}\text { 2. Considerando as estratégias de } \\
\text { relacionamento com seus pacientes, como } \\
\text { ligações para clientes antigos, envio de } \\
\text { mala direta, envio de e-mail, entre outras, } \\
\text { considero a minha situação como: }\end{array}$} \\
\hline \multicolumn{6}{|l|}{$\begin{array}{l}\text { 3. Considerando pesquisa de preço antes } \\
\text { de uma compra importante e reserva } \\
\text { financeira para a compra de materiais e } \\
\text { equipamentos, avalio meu comportamento } \\
\text { como sendo: }\end{array}$} \\
\hline \multicolumn{6}{|l|}{$\begin{array}{l}\text { 4. Quanto as estratégias para atrair novos } \\
\text { clientes para o consultório ou clínica que } \\
\text { trabalho, como anúncios, parcerias, } \\
\text { divulgação em sites de pesquisa/busca, } \\
\text { entre outras, considero minha situação } \\
\text { como sendo }\end{array}$} \\
\hline \multicolumn{6}{|l|}{$\begin{array}{l}\text { 5. Considerando a qualidade e organização } \\
\text { das informações, considero o prontuário } \\
\text { dos meus pacientes como sendo: }\end{array}$} \\
\hline \multicolumn{6}{|l|}{$\begin{array}{l}\text { 6. Considerando a atenção que dedico ao } \\
\text { meu paciente antes, durante e após a } \\
\text { consulta, classifico meu atendimento como } \\
\text { sendo: }\end{array}$} \\
\hline \multicolumn{6}{|l|}{$\begin{array}{l}\text { 7. Classifico minha vantagem competitiva } \\
\text { em relação aos meus principais } \\
\text { concorrentes como sendo: }\end{array}$} \\
\hline \multicolumn{6}{|l|}{$\begin{array}{l}\text { 8. Classifico a qualidade da comunicação } \\
\text { com a equipe com quem trabalho como } \\
\text { sendo: }\end{array}$} \\
\hline \multicolumn{6}{|l|}{$\begin{array}{l}\text { 9. Em relação à minha vida profissional, } \\
\text { considero o planejamento de estratégias } \\
\text { para atingir meus objetivos futuros como } \\
\text { sendo: }\end{array}$} \\
\hline \multicolumn{6}{|l|}{$\begin{array}{l}\text { 10. Como avalio o meu conhecimento em } \\
\text { áreas como gestão, marketing e } \\
\text { administração: }\end{array}$} \\
\hline $\begin{array}{l}\text { 11. Considerando a divulgação de meus } \\
\text { serviços por meio de material impresso ou } \\
\text { digital, incluindo redes sociais, site, folder, } \\
\text { anúncios considero minha situação como } \\
\text { sendo: }\end{array}$ & & & & & \\
\hline
\end{tabular}




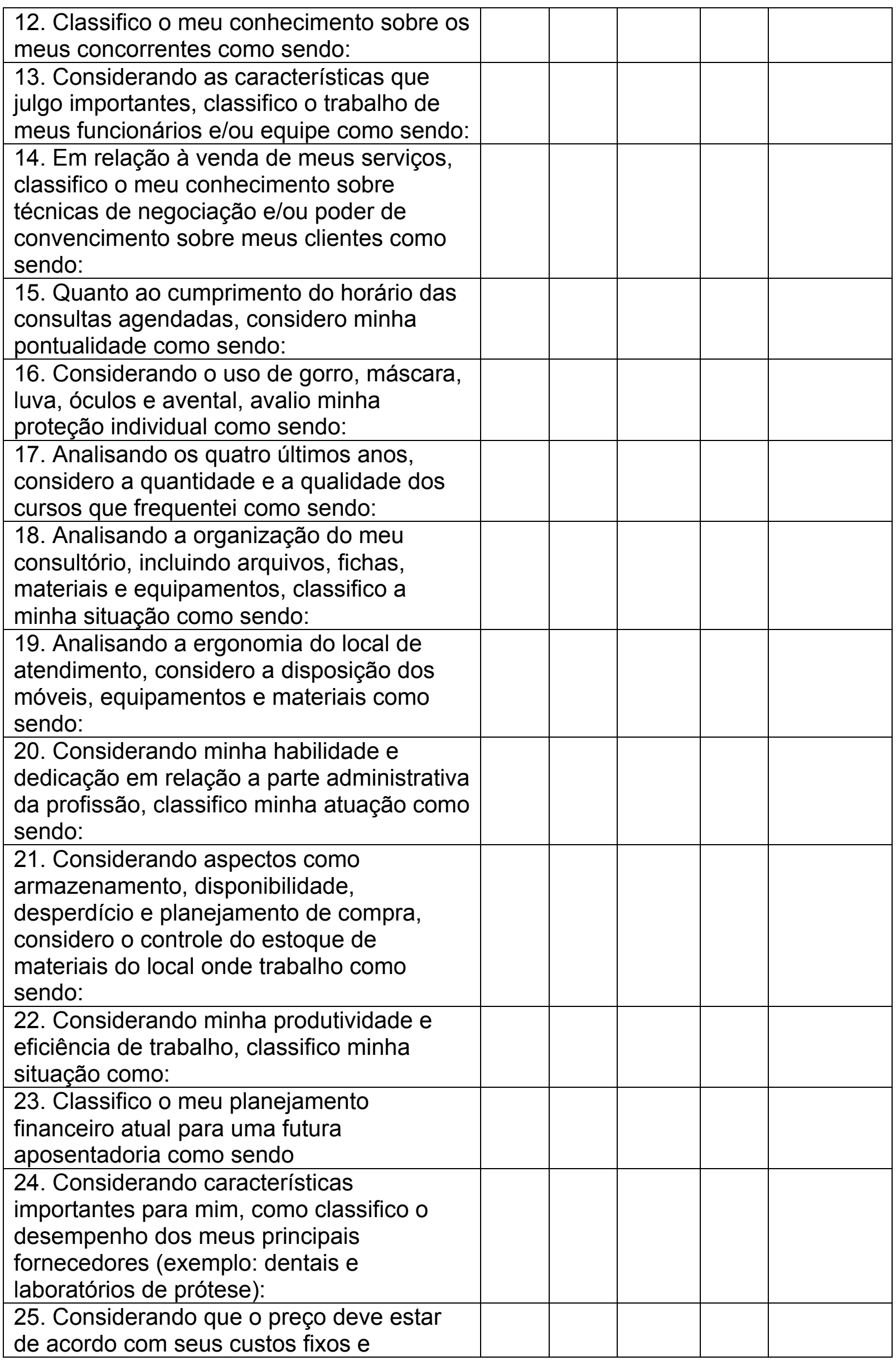




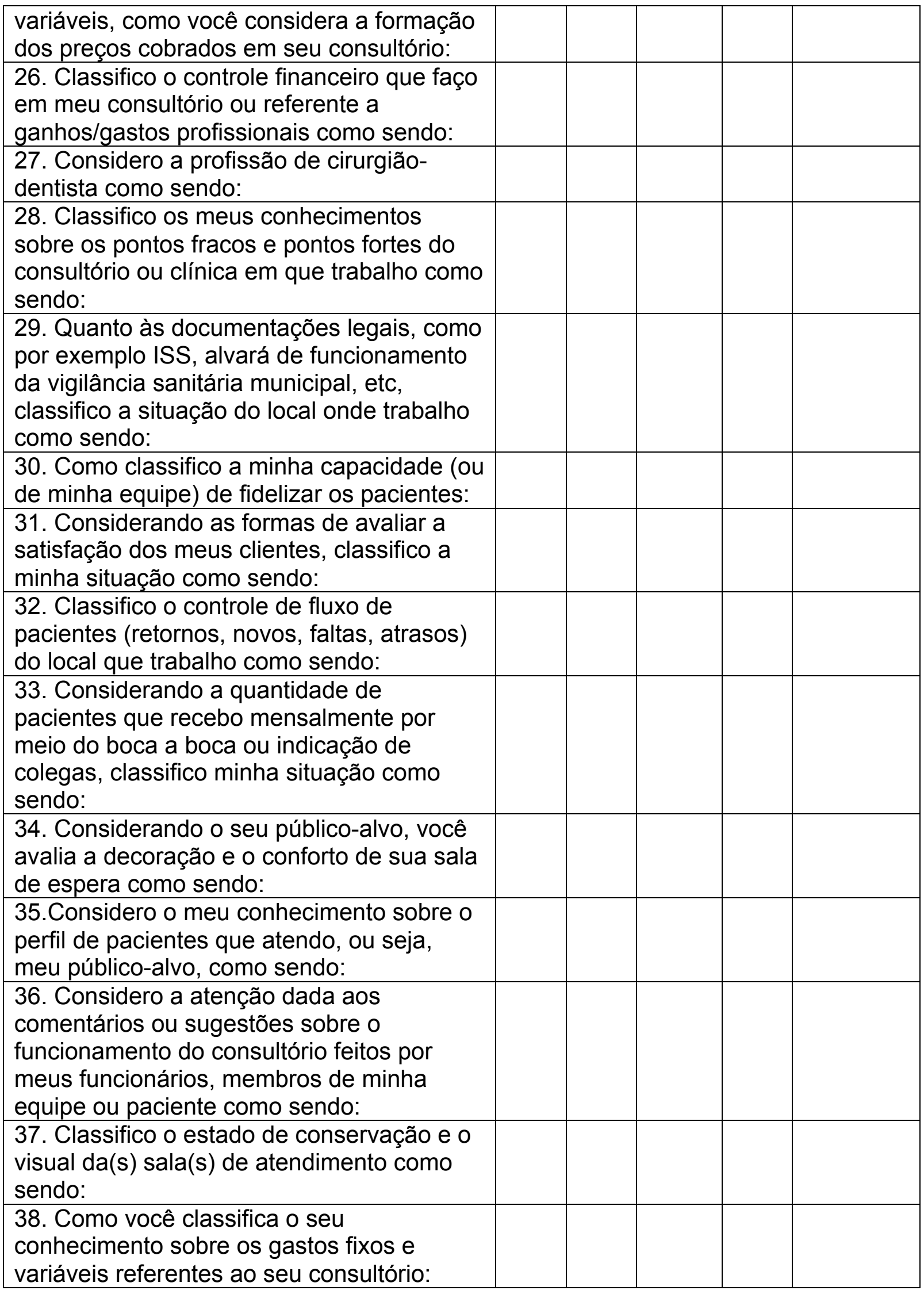


APÊNDICE B - Escala satisfação profissional

\begin{tabular}{|c|c|c|c|c|c|}
\hline Questões & $\begin{array}{l}\text { Discordo } \\
\text { fortemente }\end{array}$ & Discordo & Neutro & Concordo & $\begin{array}{l}\text { Concordo } \\
\text { fortemente }\end{array}$ \\
\hline $\begin{array}{l}\text { 01. Eu tenho pouquíssimo tempo } \\
\text { para me manter atualizado a } \\
\text { respeito dos avanços na área de } \\
\text { odontologia }\end{array}$ & & & & & \\
\hline $\begin{array}{l}\text { 02. Minha renda permite que eu } \\
\text { sustente minha família muito } \\
\text { bem }\end{array}$ & & & & & \\
\hline $\begin{array}{l}\text { 03. Eu estou tecnicamente } \\
\text { preparado para lidar com os } \\
\text { problemas odontológicos de } \\
\text { meus pacientes }\end{array}$ & & & & & \\
\hline $\begin{array}{l}\text { 04. Tenho tempo suficiente para } \\
\text { melhorar minhas habilidades } \\
\text { clínicas }\end{array}$ & & & & & \\
\hline $\begin{array}{l}\text { 05. A odontologia preenche } \\
\text { minhas atuais aspirações com a } \\
\text { carreira }\end{array}$ & & & & & \\
\hline $\begin{array}{l}\text { 06. Gostaria de deixar o meu } \\
\text { emprego/trabalho para fazer } \\
\text { outra coisa }\end{array}$ & & & & & \\
\hline $\begin{array}{l}\text { 07. Tenho suficiente tempo } \\
\text { disponível para minha vida } \\
\text { pessoal }\end{array}$ & & & & & \\
\hline $\begin{array}{l}\text { 08. A qualidade de meu pessoal } \\
\text { auxiliar deixa a desejar }\end{array}$ & & & & & \\
\hline $\begin{array}{l}\text { 09. Eu pareço mais satisfeito/a } \\
\text { com meu trabalho/emprego do } \\
\text { que realmente estou }\end{array}$ & & & & & \\
\hline $\begin{array}{l}\text { 10. Comparado a outros } \\
\text { cirurgiões-dentistas, meus } \\
\text { ganhos totais são muito menores } \\
\text { do que eu gostaria }\end{array}$ & & & & & \\
\hline $\begin{array}{l}\text { 11. Relacionar-me com } \\
\text { pacientes, para mim, é muito } \\
\text { frustrante }\end{array}$ & & & & & \\
\hline $\begin{array}{l}\text { 12. Sabendo o que eu sei hoje, } \\
\text { eu teria tomado a mesma } \\
\text { decisão de fazer odontologia } \\
\text { novamente }\end{array}$ & & & & & \\
\hline $\begin{array}{l}\text { 13. Eu perco oportunidades de } \\
\text { fornecer assistência/atendimento } \\
\text { de qualidade }\end{array}$ & & & & & \\
\hline $\begin{array}{l}\text { 14. A odontologia é a área onde } \\
\text { eu posso oferecer minha melhor } \\
\text { contribuição profissional }\end{array}$ & & & & & \\
\hline
\end{tabular}




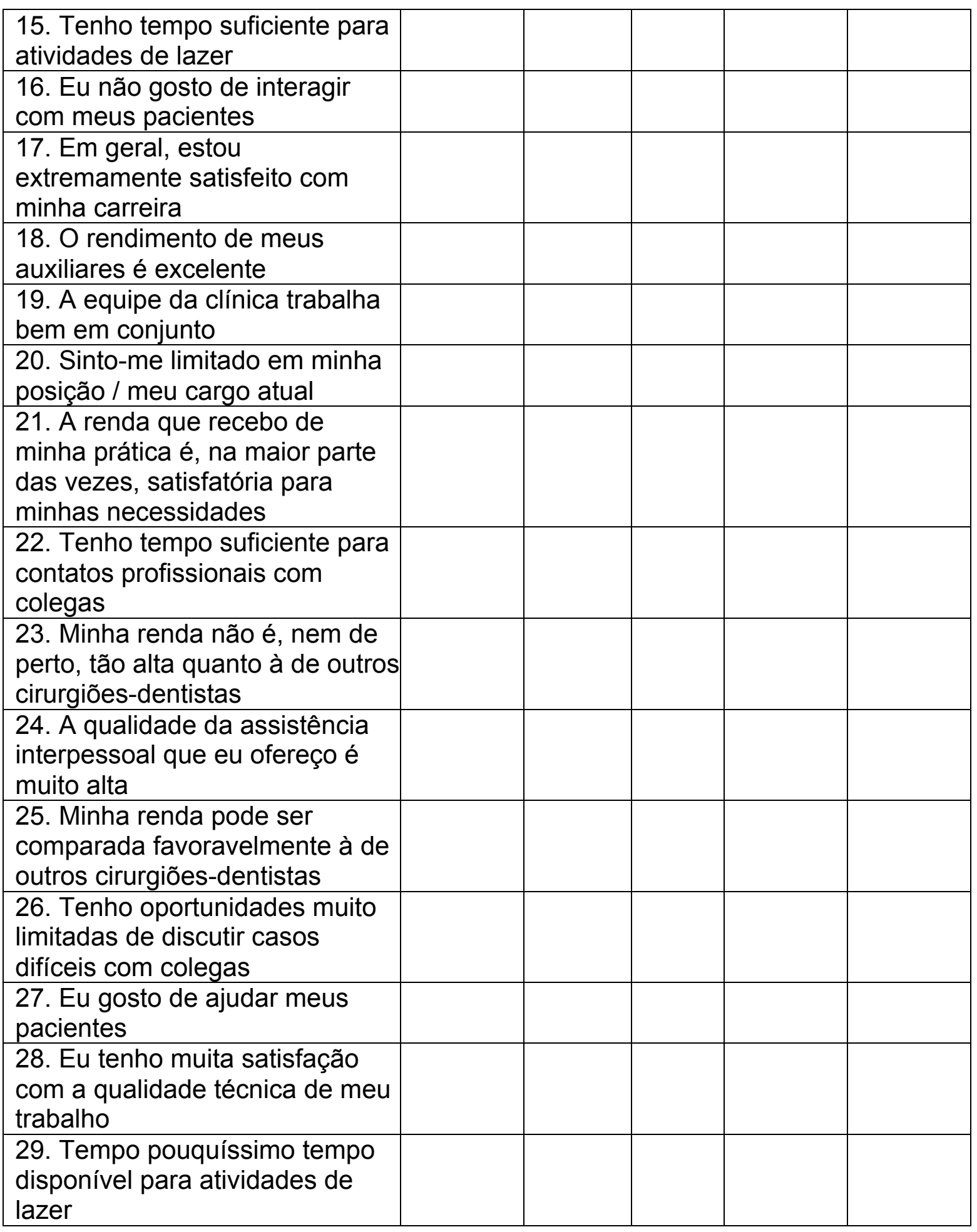


ANEXO - Parecer do Comitê de Ética em Pesquisa

\section{FACULDADE DE ODONTOLOGIA DA UNIVERSIDADE DE SÃO}

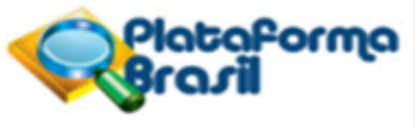

\section{PARECER CONSUBSTANCIADO DO CEP}

\section{DADOS DO PROJETO DE PESQUISA}

Título da Pesquisa: APLICAÇÃO DE FERRAMENTAS DE GESTÃO-MARKETING E SATISFAÇÃO PROFISSIONAL: ESTUDO DO PERFIL PROFISSIONAL DE IMPLANTODONTISTAS

Pesquisador: Edgard Michel Crosato

\section{Área Temática:}

Versão: 2

CAAE: 11179412.7 .0000 .0075

Instituição Proponente: Universidade de Sao Paulo

Patrocinador Principal: Financiamento Próprio

\section{DADOS DO PARECER}

Número do Parecer: 206.341

Data da Relatoria: 22/02/2013

\section{Apresentação do Projeto:}

Em odontologia, a satisfação profissional pode ser influenciada por diversos aspectos, como ambiente de trabalho, tempo de formação, prestígio percebido da profissão e dificuldades encontradas no exercício da profissão. Ainda, muitos dentistas se dizem insatisfeitos com a parte administrativa da profissão e muitos desconhecem o marketing. A proposta deste trabalho é relacionar os dados obtidos a partir de dois questionários: um questionário sobre a sobre aplicação de ferramentas de gestão e marketing e outro sobre a satisfação profissional dos cirurgiões dentistas que atuam em clínica odontológica particular na grande São Paulo. A hipótese levantada é que a aplicação das ferramentas de gestão na Odontologia pode aumentar a satisfação profissional dos cirurgiões-dentistas que atuam na atividade privada.

\section{Objetivo da Pesquisa:}

A partir de informações obtidas por meio de dois questionários: sobre perfil de satisfação profissional e aplicação de ferramentas de gestão/marketing, o presente estudo tem por objetivo relacionar os dados para descobrir possiveis associações entre os resultados dos dois instrumentos.

\section{Avaliação dos Riscos e Benefícios:}

Riscos: o preenchimento deste questionário não representa qualquer risco de ordem física e riscos mínimos de ordem psicológica. O resultado do trabalho poderá beneficiar a coletividade uma vez

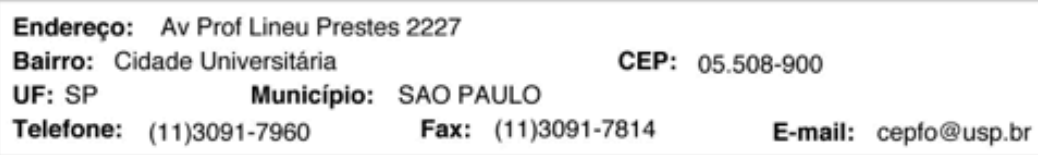




\section{FACULDADE DE ODONTOLOGIA DA UNIVERSIDADE DE SÃO}

que, se nossa hipótese for suportada, poderão ser sugeridas alterações no currículo dos cursos de graduação e ou pós-graduação do país com o objetivo de contribuir com o aumento da satisfação dos profissionais com a Odontologia.

\section{Comentários e Considerações sobre a Pesquisa:}

A pesquisa envolve duas fases, uma de validação de um questionário sobre aplicação de ferramentas de Gestão e Marketing para dentistas - clínicos gerais e na segunda fase, este questionário validado, será aplicado juntamente com um questionário sobre satisfação profissional para dentistas - implantodontistas. Esta segunda fase será realizada on-line. O questionário da primeira fase possivelmente sofrerá mudanças, sendo assim, o formato final será enviado ao CEP como adendo, como relatado pelos pesquisadores no projeto.

\section{Considerações sobre os Termos de apresentação obrigatória:}

Todos os documentos obrigatórios foram apresentados. A carta de autorização do uso da clínica ou local onde será realizada a pesquisa não foi inserida uma vez que os questionários serão realizados com cirurgiões-dentistas, em consultórios particulares ainda não previstos.

\section{Recomendações:}

Não há recomendações.

\section{Conclusões ou Pendências e Lista de Inadequações:}

Aprovado.

Tendo em vista a legislação vigente, devem ser encaminhados ao CEP-FOUSP relatórios parciais anuais referentes ao andamento da pesquisa e relatório final ao término do trabalho. Qualquer modificação do projeto original deve ser apresentada a este CEP, de forma objetiva e com justificativas, para nova apreciação.

\section{Situação do Parecer:}

Aprovado

\section{Necessita Apreciação da CONEP:}

Não

\section{Considerações Finais a critério do CEP:}

Projeto de pesquisa adequado para aprovação do CEP-FOUSP.

Endereço: Av Prof Lineu Prestes 2227

Bairro: Cidade Universitária $\quad$ CEP: $05.508-900$

UF: SP Município: SAO PAULO

Telefone: (11)3091-7960 Fax: (11)3091-7814 E-mail: cepfo@usp.br 


\section{FACULDADE DE ODONTOLOGIA DA UNIVERSIDADE DE SÃO}

SAO PAULO, 26 de Fevereiro de 2013

Assinador por:

Marcia Turolla Wanderley

(Coordenador) 